U. S. DEPARTMENT OF THE INTERIOR

Ls Geological Survey

Water Resources Division

Washington, D. C.

\title{
THE INVESTIGATION OF CHEMICAL QUALITY OF WATER IN TIDAL RIVERS
}

By Walter B. Keighton

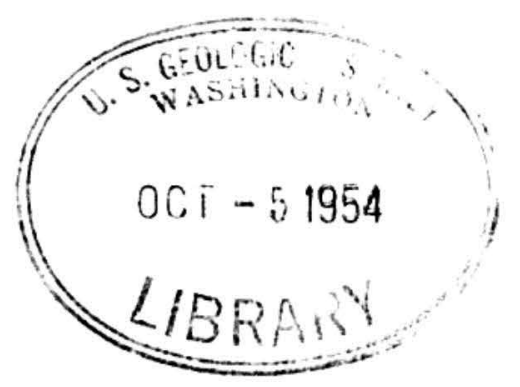

Open File Report

Prepared by Quality of Water Branch - August 1954 $54-139$ 
Page

Introduction

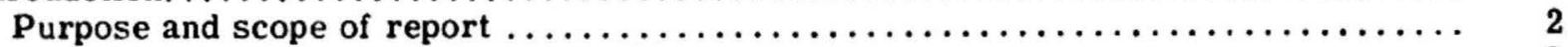

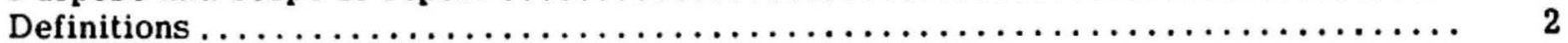

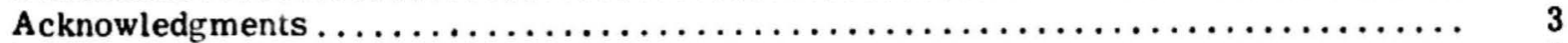

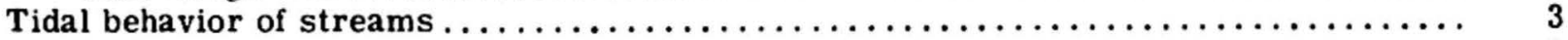

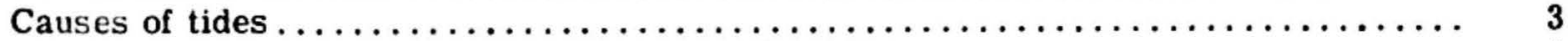

Effects of river channel characteristics on the tides $\ldots \ldots \ldots \ldots \ldots \ldots \ldots \ldots \ldots \ldots, 4$

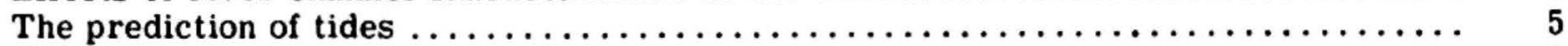

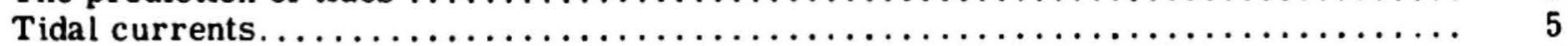

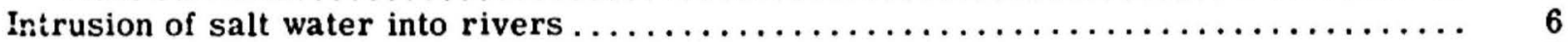

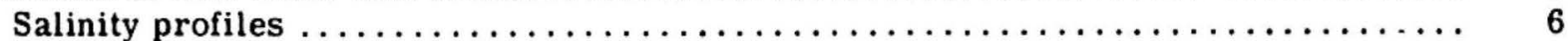

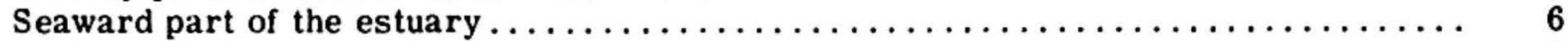

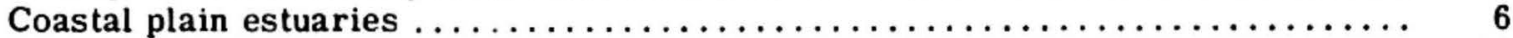

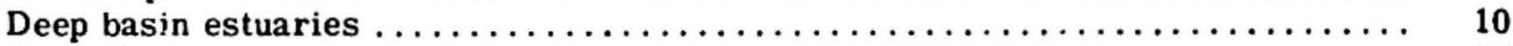

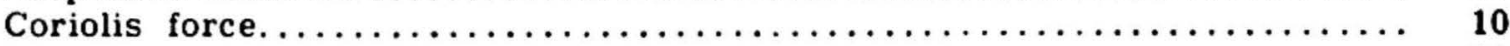

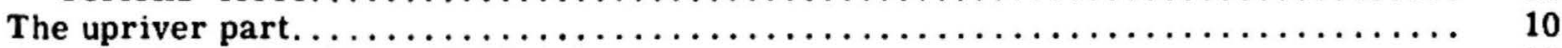

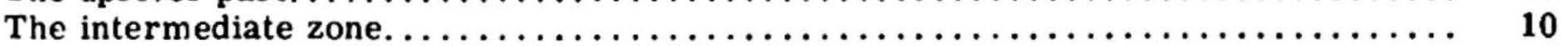

Detection of saline intrusion in a tidal river $\ldots \ldots \ldots \ldots \ldots \ldots \ldots \ldots \ldots \ldots \ldots \ldots \ldots . \ldots 12$

Composition of ocean water and river waters $\ldots \ldots \ldots \ldots \ldots \ldots \ldots \ldots \ldots \ldots \ldots, 12$

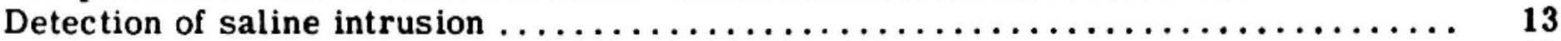

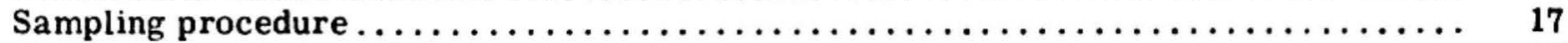

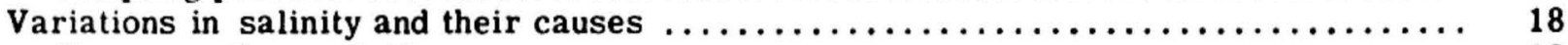

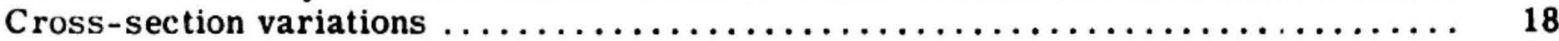

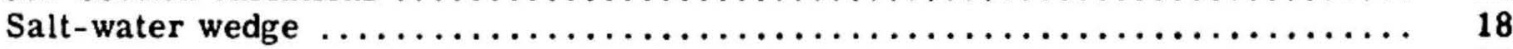

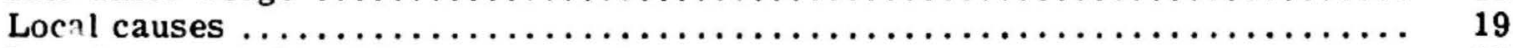

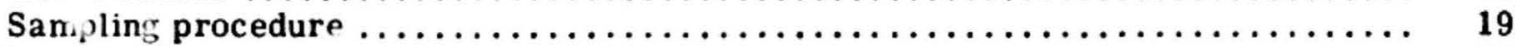

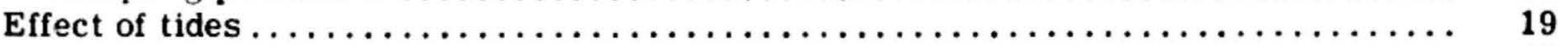

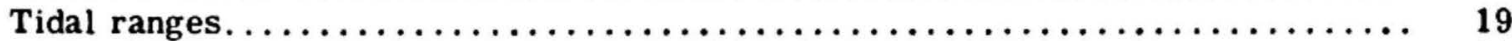

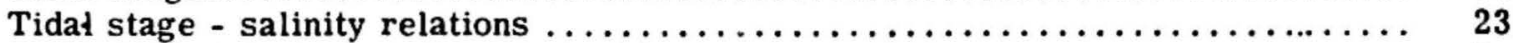

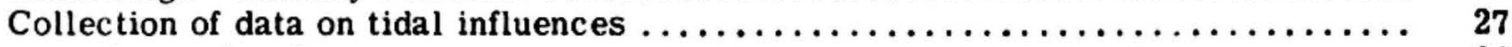

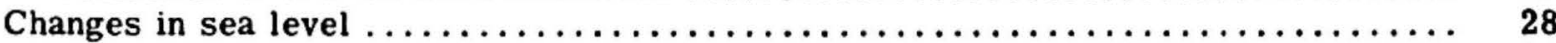

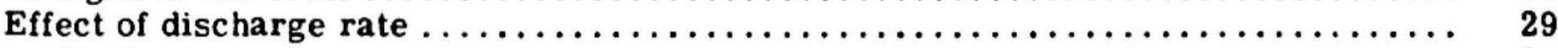

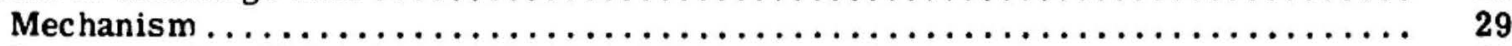

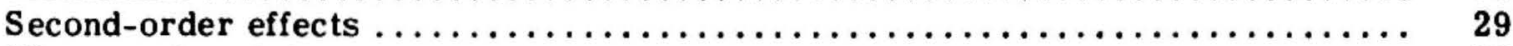

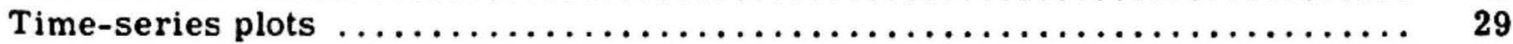

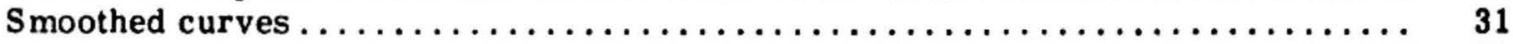

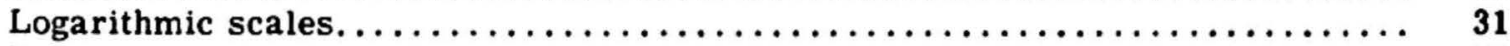

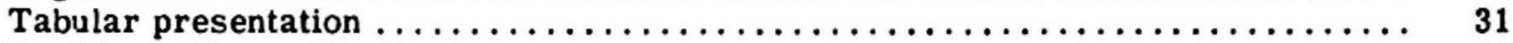

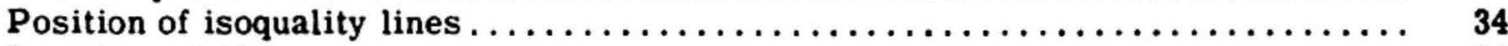

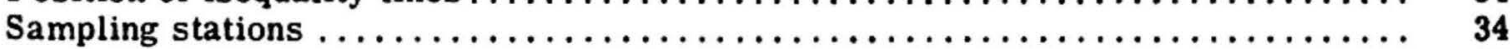

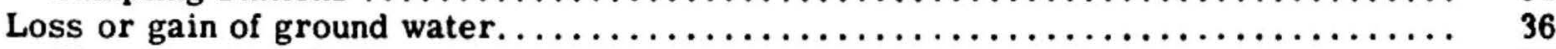

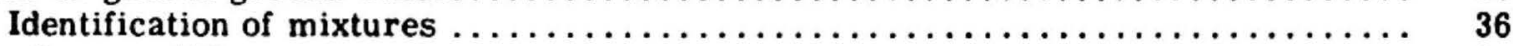

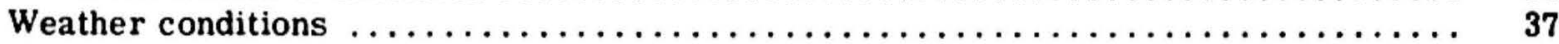

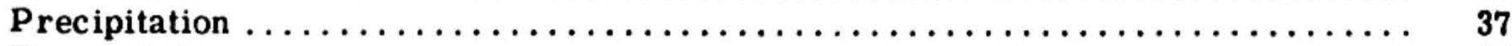

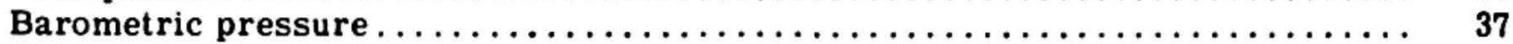

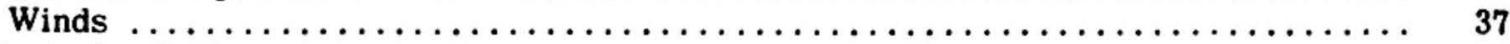

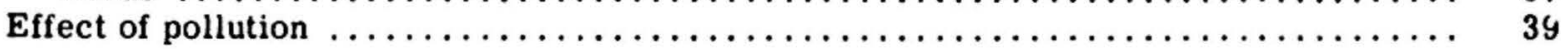




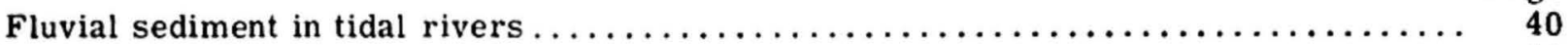

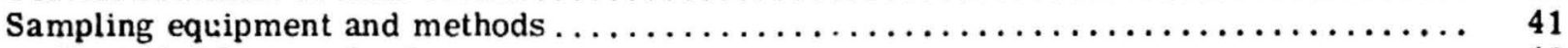

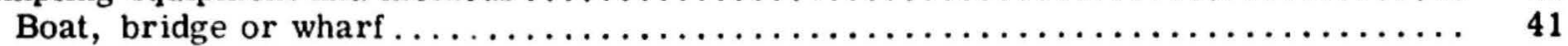

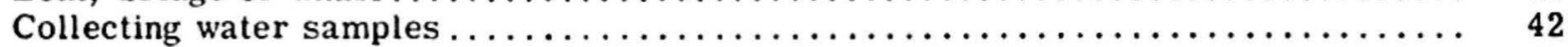

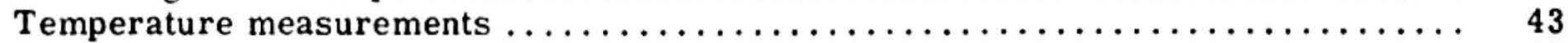

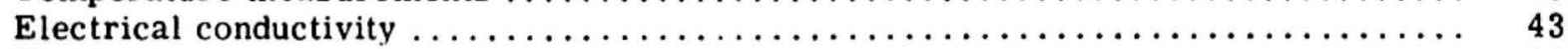

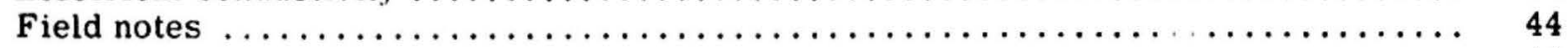

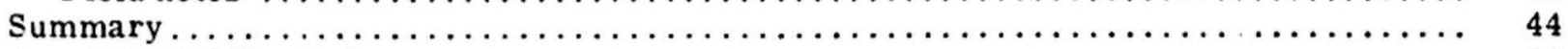

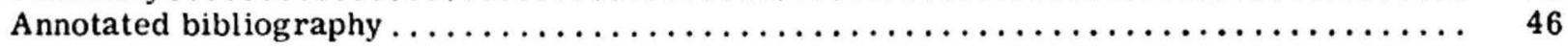

\section{ILLUSTRATIONS}

Figure 1. River profile, showing salinity as chloride ........................ Page

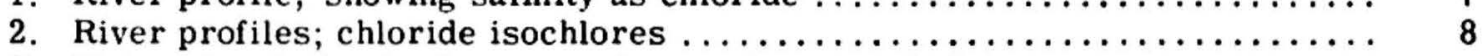

3. Water circulation in the seaward part of a coastal plain estuary......... 9

4. Idealized isometric projections showing effect of tide on distribution of fresh and salt water in Alberni harbor ..................... 11

5. Daily chloride concentrations, Delaware River at Chester, $\mathbf{P a}$, July to

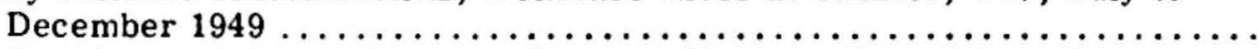

6. Daily tidal conditions: Delaware River at Chester, $\mathrm{Pa}$, July to December

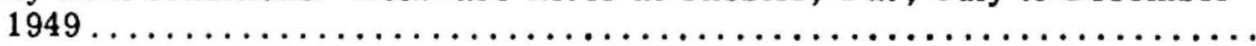

7. Relation of salinity to tidal stage: Delaware River, $1928-1934 \ldots \ldots \ldots \ldots \ldots$

8. Relation of salinity to tidal stage: Sacramento-San Joaquin Delta and the Upper Szn Francisco Bay, May to December $1929 \ldots \ldots \ldots \ldots \ldots \ldots \ldots$

9. Variation in chloride concentration during tidal cycle, Delaware River at Chester, $\mathrm{Pa}$. , July to December 1949 .

10. Daily mean water discharge, Delaware River at Trenton, N. J., June to December 1949

11. Chloride concentrations (smoothed curve): Delaware River at Chester, $\mathrm{Pa}$,

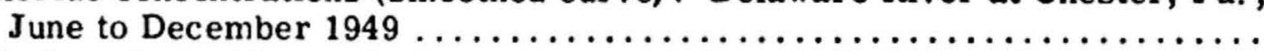

12. Relation of specific conductance to mean daily runoff, Saline River near Russell, Kansas, October 1947 to March 1948.

13. Position of conductivity 200 micromhos as related to stream flow: Lower

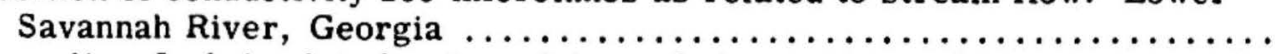

14. Langelier-Ludwig plot showing mixture of river water and ocean water $\ldots \ldots$

\section{TABLES}

Table 1. Composition of ocean water, in parts per million. ................ Page

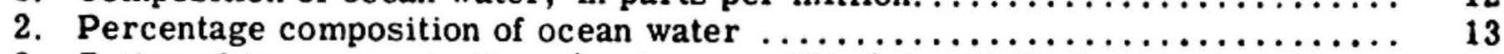

3. Ratios of ion-concentrations (parts per million) for 31 U. S. rivers and for

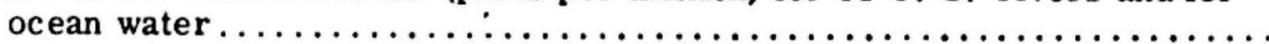

4. Intrusion of sea water into the Delaware River, $\mathbf{N}, \mathbf{J},-\mathbf{P a}, \ldots \ldots \ldots \ldots \ldots \ldots$

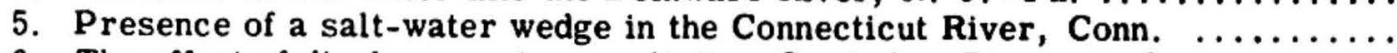

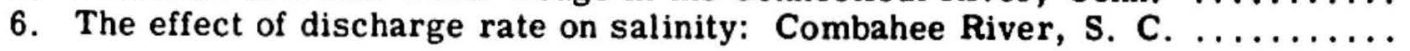




\title{
THE INVESTIGATION OF CHEMICAL QUALITY OF WATER IN TIDAL RIVERS
}

\author{
by Walter B. Keighton
}

\begin{abstract}
This report has been prepared for the guidance of personnel of the Water Resources Division who are engaged in water-quality investigations of tidal rivers. The study of tidal rivers is beset with many complexities not present in the investigation of non-tidal rivers. The periodic rise and fall of the tide may result in a corresponding periodic change in salinity at a sampling location on the tidal river. When the fresh water discharge is low, saline water may intrude up-river, and any factor changing the relative elevations of the ocean and the mean river level has an effect on the extent of salt-water intrusion. Variations in water composition between samples taken at several locations up or down river, at different depths, or at several locations across the stream are likely to be more pronounced than for similar sets of samples from a non-tidal stream. The nature of these variations and factors responsible for them are discussed, and the need for consideration of them in planning a sampling routine is stressed. The nature and mechanism of ocean-water intrusion in tidal rivers is discussed and sampling procedures for its detection are described. Illustrative examples - mostly from the work of the United States Geological Survey or State agencies - show various methods for correlating and presenting data from quality-of-water surveys of tidal rivers. Each tidal river presents an individual problem which can best be understood from a study of the factors involved. To that end the report is supplemented by an annotated bibliography of selected publications in the field.
\end{abstract}

\section{INTRODUCTION}

In a non-tidal river fresh water flows into the upper part of the $r$ iver, continuously if not steadily, and out the lower end of the river. In a tidal river, on the other hand, the normai downstream flow of the river is periodically interrupted by the flood tide and - until the tide ebbs - saline water flows upstream and mixes with the downstream flow of fresh water. Salirity increases from the fresh-water reaches of the river to the bay or ocean, but at a particular location within the tidal portion of the river salinity fluctuates as the tide floods and ebbs. For such reasons a quality-of -water investigation of a tidal river has many complexities not present in a similar study of a non-tidal stream.

In a continuously flowing non-tidal stream pollution is eventually diluted by the river water to a degree indicated by the ratio of the discharge rate of river water to the discharge rate of pollution, and a batch of dissolved waste is flushed down-stream by the on-coming fresh water from upstream. In a tidal river the flushing of pollution is more complex. Pollution introduced during the ebb tide mixes with the river water and flows downstream much as it would do in a non-tidal river. Soon, however, the tide changes and on the flood the pollution is further diluted by the water from the incoming tide and also swept back upstream until the next change of tide. Since there is a net flow downstream, the net flow of pollution is toward the ocean, but nevertheless some of it may be found upstream from the point of introduction, although usually diluted, even after several tidal cycles.

The tidal flushing of estuaries has been considered from the theoretical viewpoint by several authors (Arons, Ketchum, Pritchard, Stommel) 1/ and model studies have been made by the Corps of Engineers, U. S. Army (1952 a, b, 1953). 1/ In checking both the theories and the operation of the models, salinity data have been used extensively. It is thus important in the

$\underline{1}$ See page 46 for list of references cited. 
developmer' and application of tidal flushing theories to obtain quality-of-water data for the prototype .ver.

The collection and analysis of water samples from tidal rivers has a particular value in determining economic utilization of the water. Along tidal rivers that are navigable there is a concentration of population and industries with a resulting heavy demand for water for consumtive and non consumptive uses and as a vehicle for dilution of wastes. Basic data on the salinity of the stream, its variations and their causes, therefore have a special importance. The operation of steam-electric generating plants requires large quantities of fresh water, as do many chemical manufacturing processes. Corrosion of plant and harbor facilities is accelerated by salt water. High salinities may require the modification of chemical processes using river water, result in difficuities in treatment control, or in extreme cases cause the possible shut-down of a plant or abandonment of the river as a source of water for nunicipal or industrial supply. The extent and frequency of variations in salinity are also of considerable concern to the shellfish industry and to irrigation. The mixing of salt water with fresh water causes flocculation of colloidal and other suspended solids and consequently may be responsible for shoaling. The effect on salinity of the river water of upstream diversions to storage reservoirs, canals, or irrigation is of basic interest in long-range planning of water usage. Recently various proposals have been made for the recovery of fresh water from saline water. When the operation of such processes becomes economically feasible, knowledge of the salinity variation in the water supply may be an important factor in locating the plant. In any study of infiltration of river water into the ground-water aquifers basic data on the composition of the river water is a prerequisite.

\section{Purpose and Scope of Report}

It is the purpose of this report to point out some of the natural forces and physical factors which must be considered in planning water-quality investigations of tidal rivers and to show how these factors may affect the chemical quality of river water. Sampling procedures that will adequately determine the variable water quality are suggested, and examples are cited of water-quality investigations, showing what information has been sought, and how it has been interpreted and presented. The report closes with a bibliography of published work on the subject.

Attention is also directed to the "Bibliography on Tidal Hydraulics" (Corps of Engineers, U. S. Army, 1954) which contains additional pertinent references.

\section{Definitions}

The term "tidal river" in this report means a river in which the flow of water periodically changes its direction with the rise and fall of the tide in the ocean, alternately flowing upstrcam (flood current) and downstream (ebb current). The wide lower part of a tidal river is often called an estuary. D. W. Pritchard (1952) classifies estuaries as positive estuaries, in which the sea water is measurably diluted by land drainage, and inverse estuaries, in which evaporation exceeds the sum of land drainage and precipitation. Estuaries are classified on the basis of geomorphological structure as coastal plain estuaries, such as most of those on the eastern shore of North America, and deep basin estuaries with a shallow sill at the mouth, of which the glacial cut fiords of the Canadian Pacific Coast are examples. Both these kinds of estuaries are generally of the positive type. Mixing of sea water and fresh water is predominately due to the tides. Along the Gulf of Mexico are bar-built estuaries, characterized by a narrow channel between the estuary (or sound) and the open sea. Both positive and inverse types are known, and mixing is due to tidal action and to the wind, but chiefly the latter .

In estuaries, or at least in their lower portions, the mixture contains more sea water than fresh water and salinity measurements are of interest in determining the circulation pattern of fresh and salt water. Such information is useful in discovering the mechanism of sea-water 
intrusion, and for investigating the tidal flusting of pollution. In the upstream portion of the tidal river the water may be looked upon as fresh water contaminated with sea water. The dissolved solids content may be one or two thousand parts per million or less. Such water is of interest for domestic or industrial water supply or irrigation, and water-quality investigations in that part of the tidal river will be concerned with the variability of water quality, so that users may estimate how often the water may become unsuitable for use.

In discussions of sea-water encroachment the terms chlorinity and salinity are frequently used. Chlorinity refers to the chloride-ion concentration, (salinity to the concentration of dissolved solids of the same composition as those in sea water. Salinity of salt water is determined by measuring the specific gravity of a water sample with a hydrometer or pycnometer, noting the temperature and using a table (e.g. in Knudsen, Martin, 1901, Hydrographic

Tabellen, p. iii). It may also be estımated from the specific electrical conductance or refrative index of the water or from the dissolved solids determined by gravimetric methods. It is sometimes calculated from the equation:

$$
\text { Salinity }=30+1.805 \times \text { chlorinity }
$$

in which salinity and chlorinity are each expressed in parts per million. In this report, however, salinity is used only in a qualitative sense, for "the saltiness of the water;" chlorinity will mean parts per million of chloride, or milligrams of chloride per kilogram of solution.

\section{Acknowledgments}

This study was made under the direction of W. F. White, Jr., Chief, Chemical Quality Section, Quality of Water Branch, Washington, D. C., with the assistance of the Philadelphia Quality of Water Branch office, N. H. Beamer, district chemist. The data from which the figures 5, 9, and 11 were constructed were supplied by Scott Paper Company, Chester, Pa.

\section{TIDAL BEHAVIOR OF STREAMS}

\section{Causes of Tides}

Tides are produced by the differential gravitational action of the sun and moon, the moon having the greater effect because of its relative nearness to the earth. In the sea the tide rises twice in a lunar day of 24 hours and 50 minutes. Thus, in general, there are two high tides and two low tides each calendar day. At new and full moon, the sun and moon are acting in the same dire tion, and the difference between high and low tide is greatest. This is known as spring tide. When the moon is in the first or third quarter the attractions of the moon and sun are in partial opposition and the tidal range is less than average. This is neap tide. The moon's orbit about the earth is elliptical. When the moon is nearest the earth (in perigee) the tidal range is greater than when the moon is farthest from the earth (in apogee). Other variations in the tidal range arise from the fact that the orbit of the moon about the earth is not in the earth's equatorial plane. The two daily high tides are most nearly equal when the moon is over the equator, and differ the most when the north or south declination of the moon is greatest. These are known as the high high tide and the low high tide. An equivalent statement can be made of the two daily low tides, called the high low tide and the low low tide. On the Atlantic Coast there are two high waters and two low waters in a lunar day (semidiurnal tides) but in other places, e.g., at Mobile, Ala., on Mobile Bay in the Gulf of Mexico, the tides are chiefly diurnal, only one high and one low water each day.

To summarize, the tidal range is greatest at the time of the new moon or full moon, especially if the moon is in perigee and smallest when the moon is in its first or third quarters, particularly if the moon is in apogee at the same time. The inequality between the two daily high tides (or the two daily low tides) is least when the moon is over the equator and greatest when it is farthest north or south of the equator. Such astronomical data are found in almanacs and also in the "Tide Tables" and "Current Tables" issued by the U. S. Coast and Geodetic Survey. 
For example, on August 18, 1951, the predicted tides at Sandy Hook, N. J., were:

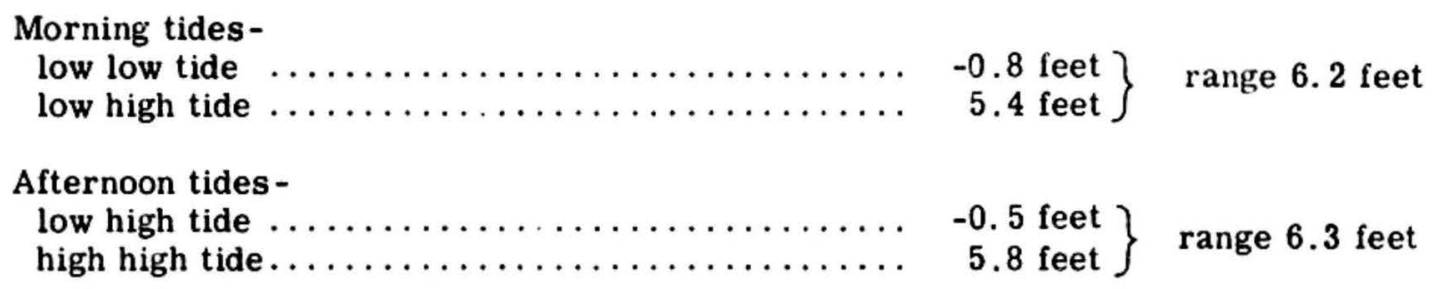

The tidal range is large, and the inequalities between the two high tides (or the two low tides) relatively small. The moon was in perigee on August 15, full on the 17th, and over the equator on the 19th.

On March 15, 1951, the predicted tides were:

\begin{tabular}{|c|c|c|}
\hline $\begin{array}{l}\text { Morning tides }- \\
\text { high high tide } \ldots \ldots \ldots \ldots \ldots \ldots \ldots \ldots \ldots \ldots \ldots \ldots \ldots \ldots \ldots \ldots \\
\text { low low tide } \ldots \ldots \ldots \ldots \ldots \ldots \ldots \ldots\end{array}$ & $\left.\begin{array}{l}4.1 \text { feet } \\
0.7 \text { feet }\end{array}\right\}$ & range 3.4 feet \\
\hline Afternoon & & \\
\hline $\begin{array}{l}\text { low high tide } \ldots \ldots \ldots \ldots \ldots \ldots \ldots \ldots \ldots \ldots \ldots \ldots \ldots \ldots \\
\text { high low tide } \ldots \ldots \ldots \ldots \ldots \ldots \ldots \ldots \ldots\end{array}$ & $\left.\begin{array}{l}3.2 \text { feet } \\
0.9 \text { feet }\end{array}\right\}$ & range 2.3 feet \\
\hline
\end{tabular}

Here the range is less and the two high tides unequal. The moon was both in apogee and in its first quarter on the $15 \mathrm{th}$, and farthest north of the equator on the $16 \mathrm{th}$. The correlation between the phases of the moon and tidal conditions is further illustrated in figure 6, page 22 .

\section{Effects of River Channel Characteristics on the Tides}

In the open ocean the tidal range may be $2 \frac{1}{2}$ to 3 feet, but when the tidal energy is concentrated in an estuary the tidal range tends to increase. In an estuary of constant width and depth, the tides would be smaller at upstream points because of the frictional dissipation of energy. Most estuaries, however, decrease in width upstream and the tidal energy is concentrated in a smaller volume, so that the tidal range usually increases upstream in spite of frictional losses.

Since time is required for the tidal oscillations to travel along an estuary or river, the time of high tide (or low tide) will vary along the waterway. In Chesapeake Bay, for exarple, high tide occurs 9 hours and 35 minutes later at Havre de Grace, Md., at the head of the bay, than at Point Lookout, Md., where the Potomac River meets the bay. Since less than 6 hours intervenes between high and low tide it is evident that the tide is rising in some parts of the Chesapeake Bay while it falls in other parts.

The shape of the waterway, its depth and width, irregularities or obstructions in the river bed or shoreline all affect the tidal behavior of a waterway. Consequently, two connecting river channels may not undergo the same tidal conditions at the same time. This is the case for the North and South Channels of Savanitiah Harbor, Ga. Where these two channels meet, southwest of Elba Island, tidal events are not simultaneous, peculiar flow conditions exist, and salinity values appear to be erratic. (Rhodes, 1950). Such a location would obviously be unsuitable for obtaining water samples representative of a river.

Widening or deepening or straightening of a river channel may alter the tidal regimen, as observed by Wicker anc Rosenzweig $(1950$. . 113) for the Delaware River at Philadelphia, about 100 miles from the ocean entrance: 
Time of observation

Mean tidal range

$1840-1883 \ldots \ldots \ldots \ldots \ldots \ldots \ldots .6 .0$ feet

Two dikes or jetties were built between 1883 and 1904 , one 12 miles, the other 38 miles below Philadelphia, obstructing free tidal flow.

$$
1904 \ldots \ldots \ldots \ldots \ldots \ldots \ldots \ldots \ldots \ldots \ldots \ldots \ldots \text { feet }
$$

Ship channel dredged.

$1912 \ldots \ldots \ldots \ldots \ldots \ldots \ldots \ldots \ldots \ldots \ldots \ldots \ldots$ feet

Two dikes were built, 17 and 50 miles below Philadelphia.

$1918 \ldots \ldots \ldots \ldots \ldots \ldots \ldots \ldots \ldots \ldots \ldots$ feet

Channel deepening and breaking away of a dike.

1933 to 1939 (average) . . . . . 5.6 feet

Channel deepening in 1940 and 1941.

1948 to 1951 (average) ....... 6.0 feet

The Prediction of Tides

The predicted times and heights of high and low waters for each day of the year are calculated by the United States Coa $i t$ and Geodetic Survey for a number of locations and are published in "Tide Tables" for each year. Hourly tide elevation measurements at a number of stations on tidal rivers are made by the Coas': and Geodetic Survey and also by the Corps of Engineers, U. S. Army.

One cannot expect exact agreement between the predicted and actual tides, especially in the upper regions of rivers subject to freshet conditions or in shallow bays with a small tidal range. An onshore wind which blows water into the bay may cause earlier and higher tides than predicted while an offshore wind may result in tides later and at less heights than predicted. From 90 to 95 per cent of the tides occur within 15 minutes of the predicted times. Since the tide changes most slowly near the times of high water and low water, 15 minutes is of little prac tical importance. (Jones, 1926).

\section{Tidal Currents}

Accompanying the vertical rise and fall of the tides, is a periodic change in the direction and strength of the horizontal motion of water or current. The upstream flow is called the flood current, the downstream flow is the ebb current. Slack water occurs when there is no horizontal motion of the water at the surface, high slack water when the flood current stops and the ebb current is about to begin, low slack water after the ebb but before the flood. The time of slack water usually does not occur at high or low tide, and its relation to the times of high and low waters varies with the place. When the river discharge is low "slack water will work up stream," i.e., it occurs later after high tide. The difference between the time at which slack water occurs and the times of high or low tide may be as great as 1 to 3 hours. "Current Tables," published annually by the U. S. Coast and Geodetic Survey, contains daily predictions of the times of slack water for a number of waterways for each day of the year.

The time lag between high water and high water slack is probably affected by the character 
of the river bottom or by changes in depth. In the Connecticut River (Connecticut W. P. A., 1938) during 1934 and 1935 the predicted time of high slack water was about $I$ hour and 30 minutes following high tide, and observations were usually in agreement with the predictions. Following the flood of March 1936, however, the interval between high water and the following high slack water was more often 50 minutes, or less. Presumably this was a result of the combined scouring action of the flood and the deposition of sediments in new places.

An informative and readable account of the tides is to be found in Rachel $L$. Carson's book, "The Sea Around Us" (Oxford University Press, 1951), Chapter II, "The Moving Tides." Tidal phenomena are described in mathematical terms in Chapter XIV of Sverdrup's book (1946).

\section{INTRUSION OF SALT WATER INTO RIVERS}

When a river flows into the ocean two aqueous fluids of different density are in contact with each other, for ocean water is about 2.6 per cent more dense than fresh water. Such a system tends to stratify horizontally, for that is the position of least potential energy. This is accomplished by the heavier ocean water flowing upstream under the lighter river water. Complete horizontal stratification is not attained, however, for the fresh water flowing downstream erodes away the entering wedge of salt water. In the upland portions of the river the water will be relatively low in dissolved solids content; near the mouth of the estuary the salinity may approach that of ocean water, but there will be a relatively short intermediate zone in which the salinity increases sharply as the water moves down-river.

\section{Salinity Profiles}

This abrupt change in salinity is readily shown by plotting a salinity profile for the river, $i$. e. by plotting the chloride concentration at a number of stations longitudinally distributed along the river. Two examples of this are shown in figures 1 and 2.

In general there is no sharp juncture between salt water and fresh water, for erosion of the salt water wedge by the fresh water current and turbulence mix the salt and fresh water to some extent. Sylvester (1952) found that in the Willapa River (Washington) estuary, at least at low stream flows, there was no variation in chloride with depth. Figure 1 (following Sylvester) shows the salinity profile for the Willapa River at low stream flow. The location of the intermediate zone between the seaward and upriver parts of the estuary is evident. Near the river mouth ( 0 miles) the cirioride concentration is nearly as great as in the Pacific Ocean $(17,500 \mathrm{ppm})$. Where the chloride concentration varies with depth, the profiles may be shown by isochlors as in figures $2 a$ and $2 b$, which are similar to figures drawn by Linder (1953) for Savannah Harbor, from model studies. These figures show, in addition to the longitudinal variation of chloride, the variation with depth, and the movement of salinity up and down the river with change of tide.

The seaward parts of estuaries have been studied to determine the mode of circulation of fresh and salt water. Such information is basic to understandi!ng the mechanism of salt-water intrusion.

\section{Seaward Part of the Estuary}

Coastal plain estuaries. --D. W. Pritchard (1952) has made a detailed study of the Chesapeake Bay, which is typical of coastal plain estuaries. There are two layers of water: a lower layer in which ocean water flows toward the head of the estuary and an upper less saline layer with a net horizontal flow down the estuary toward the ocean. (See fig. 3). Between the two is a surface of no net motion. The upper layer becomes more saline as the mouth of the estuary is approached because of the transfer of salty water from the lower layer to the upper layer. 


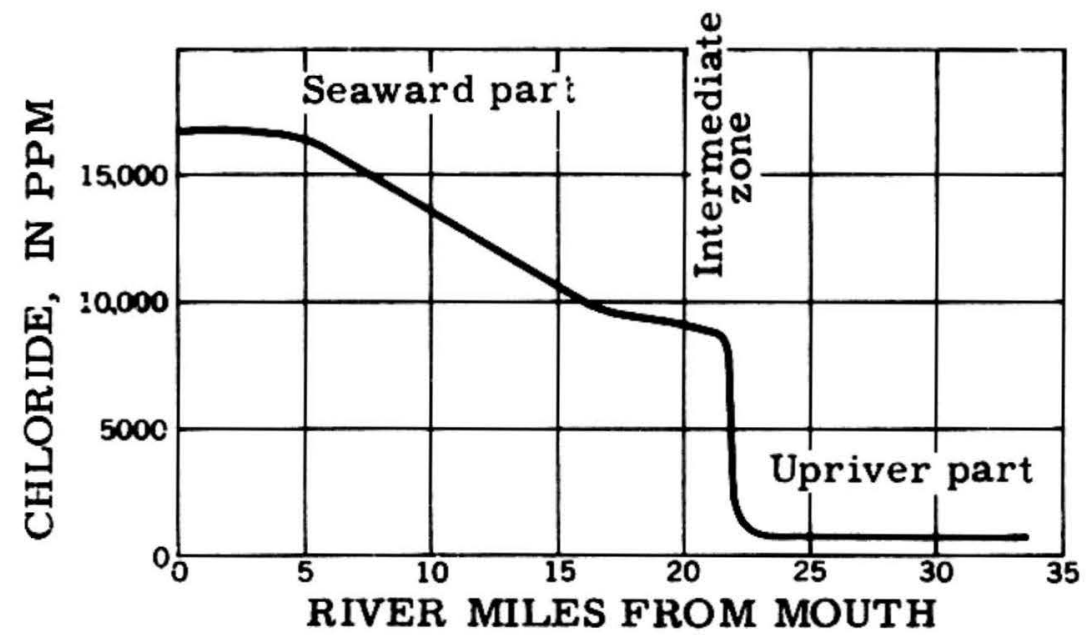

Figure 1. -- River profile, showing salinity as chloride. 


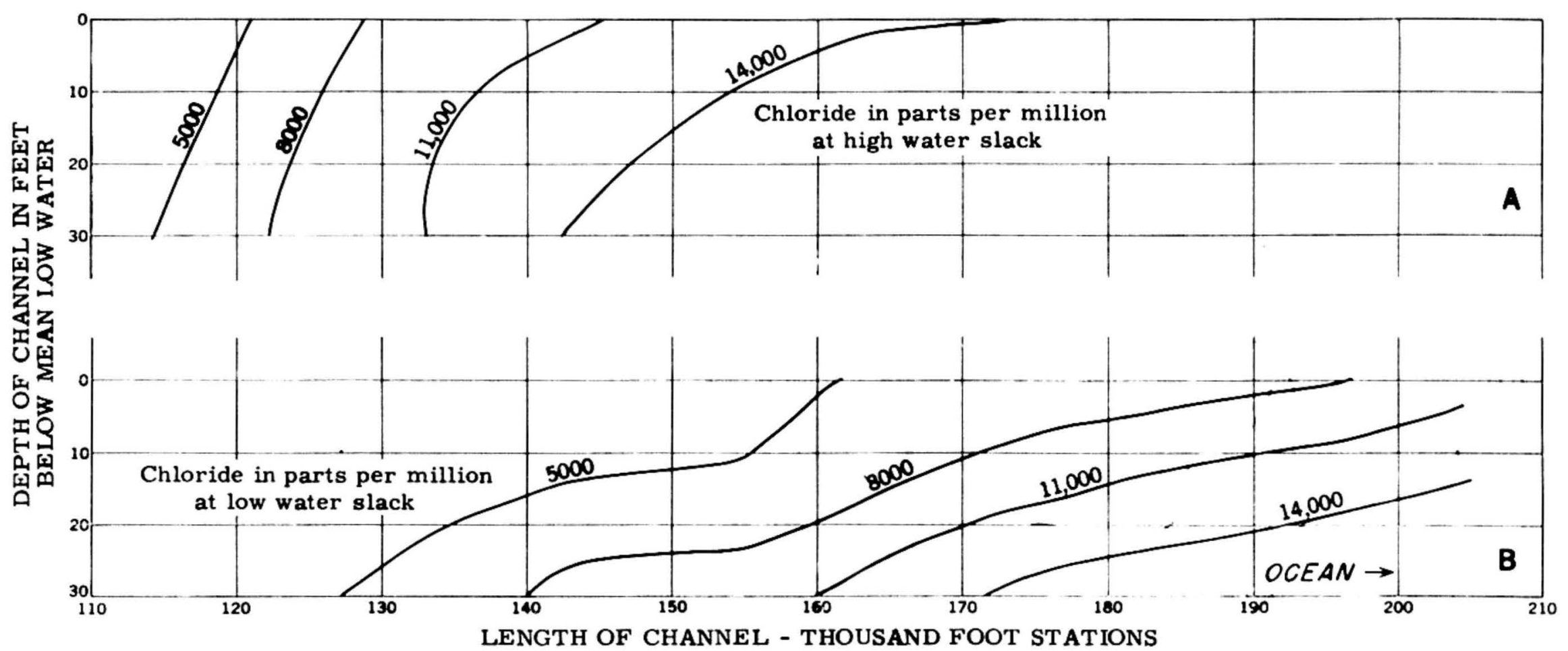

Figure 2. -- River profiles; chloride isochlors. 


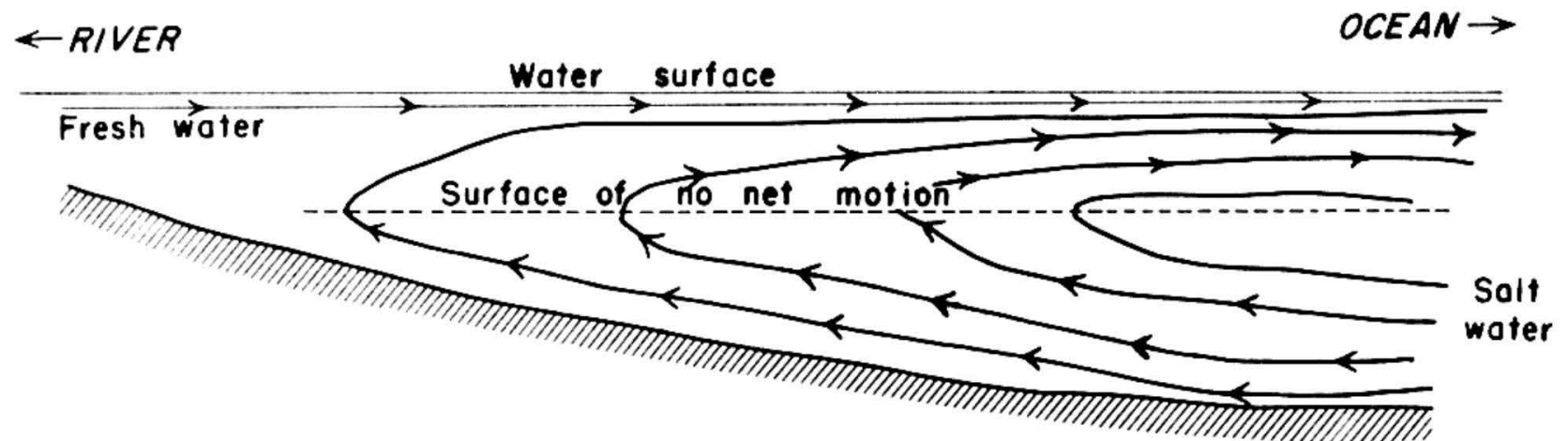

Figure 3. -- Water circulation in the seaward part of a coastal plain estuary. Longitudinal section. The arrows show the direction of net flow. 
When a salt-water wedge has been formed, surface water may move downstream during the entire tidal cycle, or if it moves upstream at all then only briefly and feebly. Bottom water, under the same conditions, flows upstream during most of the tidal cycle. On the flood tide, the current runs first and strongest near the bottom, and on the ebb tide it runs first at the surface. The current velocity is greatest at about mid-tide. At this time salinity changes most rapidly and the currents are most erratic.

Deep basin estuaries. - - The Alberni Inlet, in Canada, is a typical deep basin estuary, with precipitous sides, depths exceeding 1,000 feet in places, but with an outer threshold of about 120 feet. Fresh water from land drainage enters the estuary and moves seaward in the upper zone due to its isostatic head. It mixes with sea water in a lower layer and becomes more saline as it moves seaward. Below this zone is a middle zone in which salinity is substantially constant throughout the length of the estuary. At the interface between these two zones fresh water is transferred downward and sea water upward due to turbulence. In the middle zone the water movement is predominately upstream. Below the threshold level there is a deep zone of sea water which is undisturbed except by frictional transfer of mass and velocity. During the flood tide sea water enters the middle zone and moves toward the head. Some is transferred to the upper zone. During the ebb tide fresh water leaves the estuary in both the upper and middle zones. Where rivers enter the estuary salinity gradients are set up, that vary with the stage of the tide. Tidal forces tend to impound the river in the harbor, while isostatic forces varying with the rate of river discharge - tend to maintain the river stream. (See fig. 4.) In quite an analogous manner concentration gradients which vary with the tidal stage may be set up where streams of pollution enter the estuary.

Coriolis force. --It has been held that the deflecting force of the earth's rotation (Coriolis force) is responsible for a greater salinity on one side of a river or bay than on the other. The Coriolis force is proportional to the speed at which the water moves and is directed at right angles to the velocity: in the Northern Hemisphere to the right and in the Southern Hemisphere to the left of an observer facing in the direction of the current. In the Northern Hemisphere the water on the right-hand side of the current is of lower density than that on the left. This occurs in Chesapeake Bay (Wells, 1929: Pritchard, 1952) where isohal ines run obliquely across the estuary, i. e. salt water penetrates farther on the east side (left-hand side when facing in the direction of the current). The surface of no net motion (between the upper brackish-water layer and the lower salt-water wedge) slopes downward from east to west, so that the upper layer is deeper and the salinity lower on the right-hand side.

\section{The Upriver Part}

Above the head of tide the water in the river is fresh and may remain relatively fresh for some distance downstream from the head of tide. Even in the region where small quantities of salt water mix with the river water, through tidal action, the downstream increase in chlorinity is gradual. There is no salt-water wedge and except for local or temporary effects the water is well mixed. The relatively fresh water of the upstream part of the river is of more direct interest in quality-of-water investigations than is the saline water of the seaward part, for such water is more likely to be usable than is the saltier water of the seaward region. In this same part of the river the rate of dispersal of pollution is of primary interest.

The Intermediate Zone

Both the upriver part and the seaward part of the river are characterized by a small longitudinal gradient in salinity. Between the two is an intermediate region in which salinity changes sharply up and down the river. This is the location of the upstream tip of the saltwater wedge. These three portions of the tidal river are not delimited geographically but by the freshness or salinity of the water and by the magnitude of the longitudinal salinity gradient as compared to other parts of the river. 

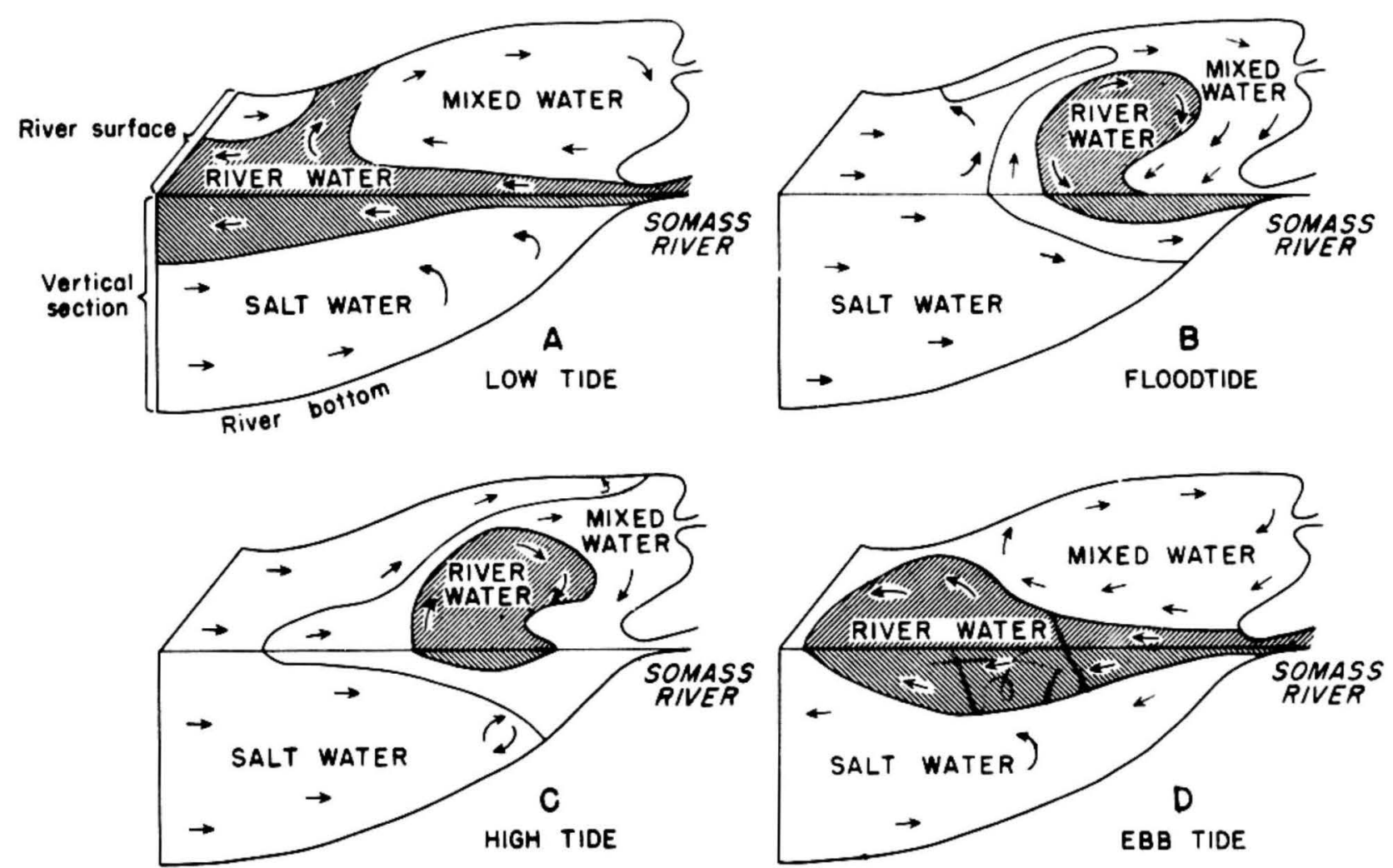

Redrawn from Tully, 1949, figure 7

Figure 4. -- Idealized isometric projections showing effect of tide on distribution of fresh and salt water in Alberni harbor. The Alberni Harbor is a saltwater inlet into which flows (from the right of the diagram) the fresh water of the Somass River. 
When the ocean surface rises at high tide the salt-water wedge intrudes further upstream, due to the increased hydrostatic pressure, and when the tide ebbs the salt-water wedge recedes toward the mouth of the river. When the fresh water discharge is small con pared to salt water influx from the ocean, the fresh water and salt water will mix within a short reach of the river. There will be at first a gradual increase in salinity from the upland portions of the river toward the sea, then a rapid increase within a relatively short mixing zone, and finally a further gradual increase toward the mouth of the river. At greater upland discharge rates the faster current of fresh water erodes away the tip of the salt-water wedge and may even override the salt water so that relatively fresh water is found near the surface for some distance seaward of the tip of the wedge. In either case, high upland discharge rates tend to move downstream the zone in which fresh and salt water mix; as the upland discharge rate decreases, the salt-water wedge creeps upstream again.

An industry at some point on the river just above the salt-water wedge may find its water supply suddenly quite saline if - due to continued low discharge - the salt-water wedge intrudes up the river. Thus it is important to know the effects of discharge rate, tidal range, and mean river level on the longitudinal displacement of the salt-water wedge. 6 bality-ofwater investigations, therefore, take on a special significance for this intermediate zone of the river.

The extent to which a salt-water wedge develops is controlled by the configuration of the channel. Shallow channels reduce the hydrostatic head which tends to force salt water up the river bed. The extent of saline intrusion increased, for example, when the ship channel of the Calcasieu River (Louisiana) was dredged from 6 feet to 30 feet. In shallow channels, also, turbulent mixing is more complete and consequently horizontal stratification is less likely. The factors affecting the shape and movement of the salt-water wedge are discussed by Rhodes (1950) and by Lindner (1953).

\section{DETECTION OF SALINE INTRUSION IN A TIDAL RIVER}

\section{Composition of Ocean Water anc River Waters}

Ocean Water differs from river water both in its greater salinity and in the relative quantities of its various constituents. Three estimates of the composition of ocean water follow:

Table 1.--Composition of ocean water, in parts per million, except specific conductance and pH

\begin{tabular}{|c|c|c|c|}
\hline Constituent & Dittmar (1884) & Thompson (1932) & Sverdrup (1946) \\
\hline $\begin{array}{l}\text { Specific conductance, } \\
\text { micromhos at } 25^{\circ} \mathrm{C} \\
\text { pH } \ldots \ldots \ldots \ldots \ldots \ldots \ldots\end{array}$ & -- & -- & $\begin{array}{l}52,000 \\
7.5-8.4\end{array}$ \\
\hline 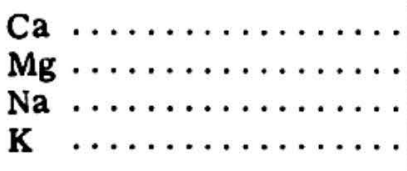 & $\begin{array}{r}419 \\
1,304 \\
10,707 \\
387\end{array}$ & $\begin{array}{r}417 \\
1,297 \\
10,720 \\
382\end{array}$ & $\begin{array}{r}400 \\
1,270 \\
10,600 \\
380\end{array}$ \\
\hline 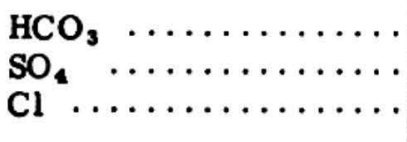 & $\begin{array}{r}150 \\
2,693 \\
19,352\end{array}$ & $\begin{array}{r}137 \\
2,705 \\
19,337\end{array}$ & $\begin{array}{c}140 \\
2,6 \\
19,000\end{array}$ \\
\hline Dissolved solids ..... & 35,012 & 35,000 & 34,500 \\
\hline
\end{tabular}


Table 2.--Percentage composition of ocean water, F. W. Clarke (1924, p. 126)

Constituent

$\mathrm{Ca}$

$\mathrm{Mg}$

$\mathrm{Na}$

$\mathbf{K}$

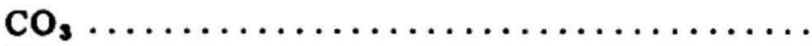

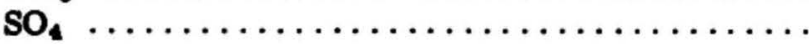

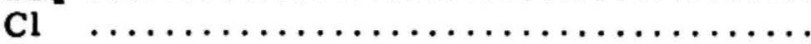

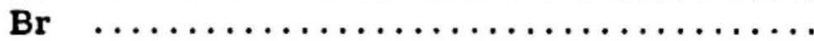

Total
Percentage of total solids

$$
1.197
$$

3.725

30.593

1.106

0.207

7.692

55.292

.188

$100.000 \%$

Ocean water differs from river water not only in its greater concentration of dissolved solids, but in the ion-concentration ratio, also. For example the ratio of the concentrations (in parts per million ) of $\mathrm{Mg} / \mathrm{Ca}$ is 3.1 for ocean water but is generally less than 0.5 for the non-tidal water of most rivers of the United States. Thus an increase of $\mathrm{Mg} / \mathrm{Ca}$ in a tidal stream may indicate sea-water intrusion. The values of several ion-concentration ratios calculated froin the composition of ocean water are shown in table 3 . These ratios for 31 rivers of the United States and the ranges of the ratios found for these rivers are shown in table 3, also.

Calculations of ion-concentration ratios were also made by Thompson (1932 b) for rivers of the United States, based on data by Clarke (1924) and on numerous Water Supply Papers of the U. S. Geological Survey.

In general the values of the ratios for river waters are less than for ocean water, but exceptions serve as a warning that each river is to be considered individually, for the river water often takes on a character peculiar to its drainage area. For example, the only rivers of the 31 investigated, for which the $\mathrm{Cl} / \mathrm{Mg}$ ratio exceeded 5. 0, were the Arkansas at Little Rock, the Red at Shreveport, La., the Brazos at Richmond and Waco, Tex., and the Rio Grande at Laredo, Tex. The Na/Mg ratio is highest for the Peedee, Savannah, Pearl, Red, and Brazos Rivers, and for the others is less than 5.0. Water used for irrigation tends to increase in dissolved solids, hardness, chloride, and sulfate; often, the percentage of calcium decreases and that of sodium increases. The $\mathrm{SO}_{4} / \mathrm{Cl}$ ratio is affected by bacterial action and the carbonate and bicarbonate are affected by photosyntizesis in waters rich in plankton.

\section{Detection of Saline Intrusion}

The intrusion of sea water into river water may be detected in several ways. Unless caused by chloride pollution a sharp increase in chloride concentration in a tidal river indicates the presence of sea water. The advance or retreat of sea-water intrusion may be followed by charting the movement of a particular isochlor, e. g., the $50 \mathrm{ppm}$ isochlor (or any chloride concentration higher than normally found immediately above the head of tide), or the $200 \mathrm{ppm}$ isochlor (on the basis that so high a chlorinity as a result of sea-water intrusion is objectionable to many industries). The extent of sea-water intrusion may also be detected by an increase in specific electrical conductance. Sea-water contamination is distinguished from industrial pollution by determining the change in several of the ion-ratios resulting from the increase in chloride content or electrical conductance.

As an illustration of the intrusion of sea water into a tidal river consider the following data for the Delaware River for November 1-2, 1949, a time of low water discharge (see table 4): 
Table 3. --Ratios of ion-concentrations (parts per million) for $31 \mathrm{U}$. S. rivers and for ocean water (in general based on yearly averages)

\begin{tabular}{|c|c|c|c|c|c|c|c|c|c|c|}
\hline \multirow[t]{2}{*}{ Date } & \multirow[t]{2}{*}{ River } & \multirow[t]{2}{*}{ Sampling location } & \multicolumn{2}{|c|}{$\begin{array}{c}\text { Clarke, F. W. } \\
\text { Bull. } 770\end{array}$} & \multirow{2}{*}{$\frac{\mathrm{Cl}}{\mathrm{CO}_{3}}$} & \multirow{2}{*}{$\frac{\mathrm{Cl}}{\mathrm{SO}_{4}}$} & \multirow{2}{*}{$\frac{\mathrm{Cl}}{\mathrm{Mg}}$} & \multirow{2}{*}{$\frac{\mathrm{Na}}{\mathrm{Mg}}$} & \multirow{2}{*}{$\left|\frac{\mathrm{Na}+\mathrm{K}}{\mathrm{Ca}+\mathrm{Mg}}\right|$} & \multirow{2}{*}{$\frac{\mathrm{Mg}}{\mathrm{Ca}}$} \\
\hline & & & Page & Col. & & & & & & \\
\hline $\begin{array}{l}1905-06 \\
1906-07 \\
1906-07 \\
1906-07\end{array}$ & $\begin{array}{l}\text { Androscoggin River } \\
\text { Merrimack River } \\
\text { Hudson River } \\
\text { Raritan River } \\
\text { Delaware River }\end{array}$ & $\begin{array}{l}\text { at Brunswick, Maine } \\
\text { above Concord, N. H. } \\
\text { at Hudson, N. Y. } \\
\text { at Bound Brook, N. J. } \\
\text { at Lambertville, N. J. }\end{array}$ & $\begin{array}{l}76 \\
76 \\
76 \\
76 \\
76\end{array}$ & $\begin{array}{l}\text { C } \\
\text { D } \\
\text { E } \\
\text { F } \\
\text { G }\end{array}$ & $\begin{array}{r}0.2 \\
.3 \\
.1 \\
.2 \\
.1\end{array}$ & $\begin{array}{r}1.9 \\
.7 \\
.2 \\
.4 \\
.2\end{array}$ & $\begin{array}{r}2.1 \\
2.1 \\
1.0 \\
1.2 \\
.9\end{array}$ & $\begin{array}{l}2.3 \\
1.5 \\
1.7 \\
2.0 \\
1.4\end{array}$ & $\begin{array}{r}0.4 \\
.3 \\
.3 \\
.6 \\
.4\end{array}$ & $\begin{array}{l}0.2(\mathrm{a}) \\
.2 \\
.2 \\
.3 \\
.3\end{array}$ \\
\hline $\begin{array}{l}1944-47 \\
1906-07 \\
1945-46 \\
1906-07 \\
1921\end{array}$ & $\begin{array}{l}\text { Delaware River } \\
\text { Susquehanna River } \\
\text { Susquehanna River } \\
\text { Potomac River } \\
\text { Potomac River }\end{array}$ & $\begin{array}{l}\text { at Morrisville, Pa. } \\
\text { at Danville, Pa. } \\
\text { at Danville, Pa. } \\
\text { at Cumberland, Md. } \\
\text { at Great Falls, Md. }\end{array}$ & $\begin{array}{l}76 \\
77 \\
77\end{array}$ & $\begin{array}{l}\mathbf{H} \\
\mathbf{I} \\
\mathbf{K}\end{array}$ & $\begin{array}{l}.2 \\
.3 \\
.2 \\
.4 \\
.1\end{array}$ & $\begin{array}{l}.2 \\
.3 \\
.1 \\
.1 \\
.2\end{array}$ & $\begin{array}{r}1.0 \\
1.8 \\
.5 \\
1.4 \\
.6\end{array}$ & $\begin{array}{r}-\overline{1} \\
1.7 \\
.6 \\
1.7 \\
.5\end{array}$ & $\begin{array}{l}.2 \\
.4 \\
.2 \\
.3 \\
.2\end{array}$ & $\begin{array}{l}3 \\
.2(b) \\
.3 \\
.2(b) \\
.2\end{array}$ \\
\hline $\begin{array}{l}1906-07 \\
1906-07 \\
1948-49 \\
1906-07 \\
1948-49\end{array}$ & $\begin{array}{l}\text { Jaines River } \\
\text { Roanoke River } \\
\text { Roanoke River } \\
\text { Neuse River } \\
\text { Neuse River }\end{array}$ & $\begin{array}{l}\text { at Richmond, Va. } \\
\text { at Randolph, Va. } \\
\text { Roanoke Rapids, N. C. } \\
\text { at Raleigh, N. C. } \\
\text { at Goldsboro, N. C. }\end{array}$ & $\begin{array}{l}77 \\
77 \\
77\end{array}$ & $\begin{array}{l}\mathrm{L} \\
\mathrm{N} \\
\mathrm{O}\end{array}$ & $\begin{array}{l}.1 \\
.1 \\
.2 \\
.2 \\
.6\end{array}$ & $\begin{array}{r}.3 \\
.5 \\
.6 \\
1.3 \\
1.1\end{array}$ & $\begin{array}{r}.8 \\
.6 \\
1.3 \\
2.4 \\
3.6\end{array}$ & $\begin{array}{r}2.0 \\
1.4 \\
-- \\
3.8 \\
--\end{array}$ & $\begin{array}{r}.4 \\
.5 \\
.6 \\
1.1 \\
1.1\end{array}$ & $\begin{array}{l}.2 \\
.4 \\
.4 \\
.3 \\
.4\end{array}$ \\
\hline $\begin{array}{l}1906-07 \\
1906-07 \\
1906-07 \\
1946-47 \\
1906-07\end{array}$ & $\begin{array}{l}\text { Cape Fear River } \\
\text { Peedee River } \\
\text { Wateree River } \\
\text { Wateree River } \\
\text { Savannah River }\end{array}$ & $\begin{array}{l}\text { at Wilmington, N. C. } \\
\text { at Pee Dee, N. C. } \\
\text { near Camden, S. C. } \\
\text { near Camden, S. C. } \\
\text { near Augusta, Ga. }\end{array}$ & $\begin{array}{l}78 \\
78 \\
78 \\
78\end{array}$ & $\begin{array}{l}\mathbf{P} \\
\mathbf{Q} \\
\mathbf{S} \\
\mathbf{T}\end{array}$ & $\begin{array}{l}.5 \\
.2 \\
.2 \\
.3 \\
.1\end{array}$ & $\begin{array}{r}1.8 \\
.8 \\
.7 \\
.7 \\
.4\end{array}$ & $\begin{array}{l}3.9 \\
2.4 \\
1.6 \\
2.1 \\
2.6\end{array}$ & $\begin{array}{r}4.3 \\
5.7 \\
4.0 \\
-- \\
11.8\end{array}$ & $\begin{array}{l}1.1 \\
1.1 \\
1.1 \\
1.0 \\
1.9\end{array}$ & $\begin{array}{l}.3 \\
.2 \\
.3 \\
.4 \\
.1\end{array}$ \\
\hline $\begin{array}{l}1906-07 \\
1946-47 \\
1906-07 \\
1906-07 \\
1906-07\end{array}$ & $\begin{array}{l}\text { Saluda River } \\
\text { Saluda River } \\
\text { Alabama River } \\
\text { Tombigbee River } \\
\text { Pearl River }\end{array}$ & $\begin{array}{l}\text { near Columbia, S. C. } \\
\text { at Chapels, S. C. } \\
\text { at Selma, Ala. } \\
\text { near Epes, Ala. } \\
\text { near Jackson, Miss. }\end{array}$ & $\begin{array}{l}78 \\
79 \\
79 \\
79\end{array}$ & $\begin{array}{l}\mathbf{R} \\
\mathbf{E} \\
\mathbf{F} \\
\mathbf{G}\end{array}$ & $\begin{array}{l}.2 \\
.3 \\
.1 \\
.1 \\
.2\end{array}$ & $\begin{array}{l}.7 \\
.8 \\
.2 \\
.5 \\
.5\end{array}$ & $\begin{array}{r}2.7 \\
2.4 \\
.8 \\
1.7 \\
3.1\end{array}$ & $\begin{array}{r}-- \\
-- \\
3.3 \\
4.5 \\
6.5\end{array}$ & $\begin{array}{r}.6 \\
1.6 \\
.7 \\
.5 \\
1.1\end{array}$ & $\begin{array}{l}.2 \\
.4 \\
.2 \\
.1 \\
.2\end{array}$ \\
\hline $\begin{array}{l}1905-06 \\
1906-07 \\
1903-? \\
1906-07 \\
1945-50\end{array}$ & $\begin{array}{l}\text { Mississippi River } \\
\text { Missouri River } \\
\text { Arkansas River } \\
\text { Arkansas River } \\
\text { Arkansas River }\end{array}$ & $\begin{array}{l}\text { at New Orleans, La. } \\
\text { near Ruegg, Mo. } \\
\text { near Rockyford, Colo. } \\
\text { at Little Rock, Ark. } \\
\text { at Little Rock, Ark. }\end{array}$ & $\begin{array}{l}80 \\
84 \\
71 \\
86\end{array}$ & $\begin{array}{l}\mathbf{H} \\
\mathbf{C} \\
\mathbf{E}\end{array}$ & $\begin{array}{r}.2 \\
.1 \\
1.9 \\
3.3 \\
2.8\end{array}$ & $\begin{array}{r}.4 \\
.1 \\
.1 \\
3.2 \\
3.7\end{array}$ & $\begin{array}{r}1.2 \\
.8 \\
1.3 \\
14.7 \\
16.0\end{array}$ & $\begin{array}{l}-- \\
1.9 \\
3.8 \\
-- \\
--\end{array}$ & $\begin{array}{r}.3 \\
.6 \\
.9 \\
3.3 \\
1.9\end{array}$ & $\begin{array}{l}.3 \\
.3 \\
.3 \\
.4 \\
.2\end{array}$ \\
\hline
\end{tabular}


Table 3. --Ratios of ion-concentrations (parts per million) for $31 \mathrm{U}$. S. rivers and for ocean water--Continued (in general based on yearly averages)

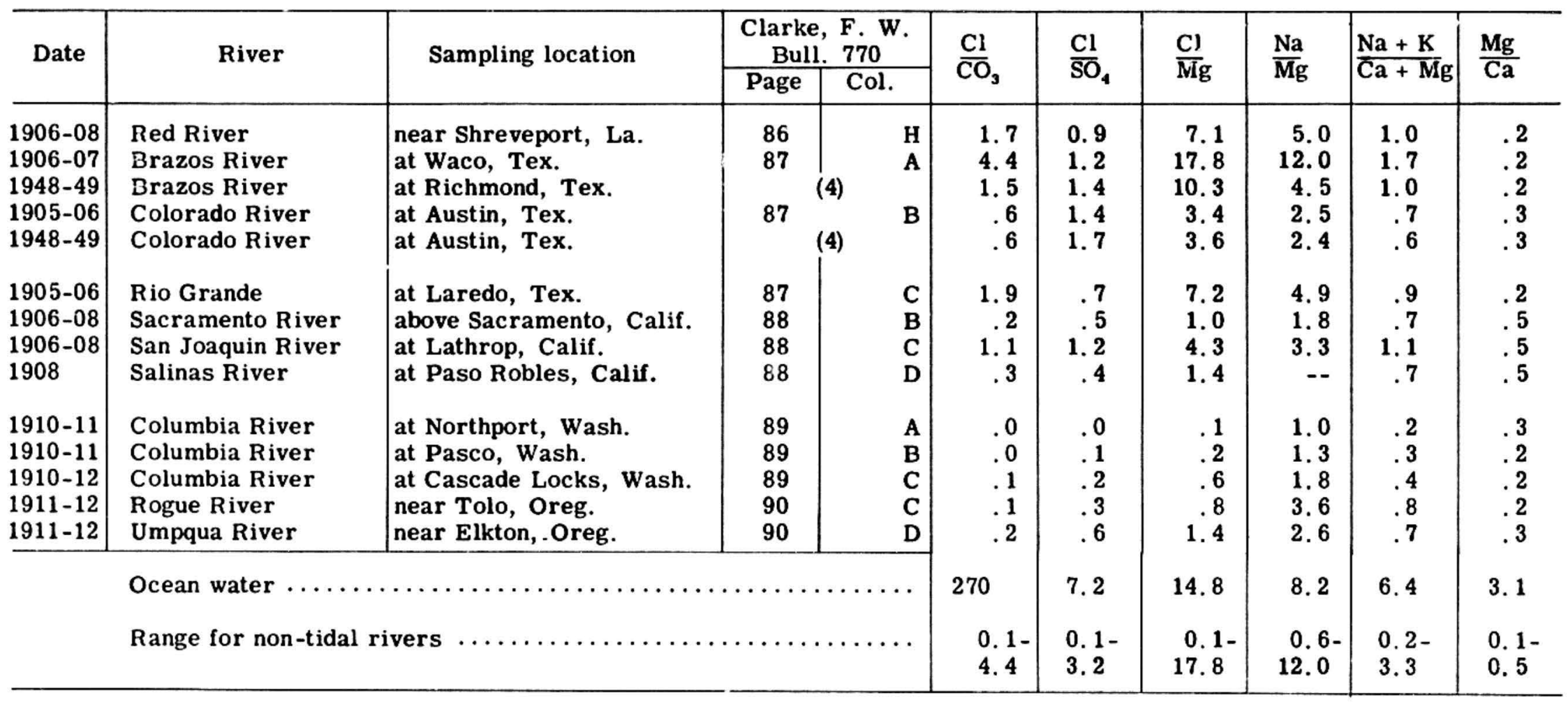

Notes:

(a) "profoundly modified by drainage from factories and pulp mills."

(b) "shows the effects of contamination by coal-mine drainage."

References:

(1) Pennsylvania Dept. of Commerce State Planning Board, 1947, industrial utility of water in Pennsylvania. Chemical character of surface water 1944-46. Pub. 17, p. 86, 102, 1951, Chemical character of surface water in Pennsylvania, $1946-49$, Pub. 23, p. 5.

(2) Pauszek, F. H. , 1950, Chemical character of surface waters of North Carolina 1948-49, Bull. 52, v. 5, Division of Water Resources and Engineering, North Carolina Dept. of Conservation and Development.

(3) Lamar, W. L., 1948, Chemical character of surface waters of South Carolina 1945-47, Bull. 16, South Carolina Research, Planning and Development Board.

(4) Texas State Board of Water Engineers, 1950, Chemical composition of Texas surface waters, 1949. 
Table 3. --Ratios of ion-concentrations (parts per million) for $31 \mathrm{U}$. S. rivers and for ocean water--Continued (in general based on yearly averages)

\section{References--Continued:}

(5) Saunders, J. L. and Billingsley, G. A., 1950, Surface-water resources of Arkansas; Geurin, J. W. , 1951, Chemical composition of Arkansas surface waters, 1949; Geurin, J. W. , 1952, Chemical composition of Arkansas surface waters, 1950; University of Arkansas, Institute of Science and Technology, Fayetteville, Ark. 
Table 4. --Intrusion of sea water into the Delaware River, N. J. - Pa.

\begin{tabular}{|c|c|c|c|c|}
\hline $\begin{array}{l}\text { Ratio } \\
\text { (ppm) }\end{array}$ & $\begin{array}{c}\text { At Bristol, } \\
\text { Pa. }\end{array}$ & $\begin{array}{l}\text { At Vine St. , } \\
\text { Phila. , Pa. }\end{array}$ & $\begin{array}{l}\text { At Marcus Hook, } \\
\text { Pa. }\end{array}$ & Ocean \\
\hline$\frac{\mathrm{Cl}}{\mathrm{CO}_{3}} \cdots \cdots \cdots$ & 0.4 & 1.9 & 134 & 270 \\
\hline$\frac{\mathrm{Cl}}{\mathrm{SO}_{4}} \cdots \cdots \cdots$ & 0.3 & 0.9 & 4.7 & 7.2 \\
\hline$\frac{\mathrm{Cl}}{\mathrm{Mg}} \cdots \ldots \ldots$ & 1.5 & 4.4 & 12.4 & 14.8 \\
\hline$\frac{\mathrm{Na}}{\mathrm{Mg}} \cdots \cdots \cdots$ & 1.3 & 3.2 & $T .4$ & 8.2 \\
\hline$\frac{\mathrm{Mg}}{\mathrm{Ca}} \ldots \ldots \ldots$ & 0.4 & 0.5 & 1.9 & 3.1 \\
\hline $\begin{array}{l}-\overline{-}-\overline{-} \\
\mathrm{Cl}, \text { ppm } \ldots\end{array}$ & $--\frac{-}{11}$ & ------ & 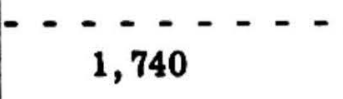 & - \\
\hline $\begin{array}{l}\text { Dissolved } \\
\text { solids, ppm. }\end{array}$ & 124 & 228 & 3,940 & 35,012 \\
\hline
\end{tabular}

The water is considered to be very little, if at all, contaminated with sea water at Bristol, although this point is within the tidal reach of the river. At Vine Street, Philadelphia, 22 miles downstream from Bristol, there is evidence of sea-water contamination in the rising values of all the ratios as well as in increases in chloride and dissolved solids. At Marcus Hook, 21 miles farther downstream, sea-water contamination is quite evident. However, the fact that each of these ratios approach that for sea water as the sampling point approaches the river mouth is evidence that the contamination is largely from the ocean.

\section{Sampling Procedure}

In a water-quality investigation of a tidal river it is desiratle to establish the water quality at several sampling stations on the river each day. Such a task is too extensive for actual measurement but can ie accomplished by judicious interpolation, both in time and in geographical location. From such data can be calculated (1) the range of quality, e. g., salinity at any location, (2) the rate of advance or retreat of salt water, and (3) the maximum extent of salt-water intrusion for the period of record.

At least one sampling station will be required at some point in the upland portion of the stream in order to estab:ish the character of the fresh water entering the tidal reach of the stream. Frequent sampling is desirable at this station, e. g. , 10-day composites of daily samples for complete chemical analysis. The number and location of stations in the tidal reach of the river will be determined by many factors, some of them discussed in subsequent sections of this report. In previous investigations the distance between sampling stations has usually been from 1 to 5 miles, although at times closer than a mile or farther apart than 5 miles. Some useful information may be obtained from weekly sampling, although daily sampling, especially at times of low fresh water discharge, will be far more productive. If the sampling is less frequent than daily or if the sampling stations are far separated, supplementary profile (longitudinal) sampling by boat may be necessary in the critical reaches.

If a representative river water sample is desired, the sampling station should be far enough downstream from any tributary to permit thorough mixing of the tributary water with that of the 
main river. It is also to be noted that tributary water may be carried upstream on the flood tide.

\section{VARIATIONS IN SALINITY AND THEIR CAUSES}

\section{Cross-section Variations}

Salt-water wedge.--As already described, ocean wrter frequently intrudes upstream as a wedge moving along the river bed, the vertical thickness of the wedge being greatest near the mouth of the river and decreasing upstream. At times, salt water may be movirg upstream a long the river bottom while less saline water directly above it is flowing downstream. The presence of a salt-water wadge is indicated by the data in table 5, "Presence of a salt-water wedge in the Connecticut River." (Connecticut WPA, 1938).

Taole 5. --Presence of a salt-water wedge in the Connecticut River, Conn. Chloride, in parts per million, at high-water slack

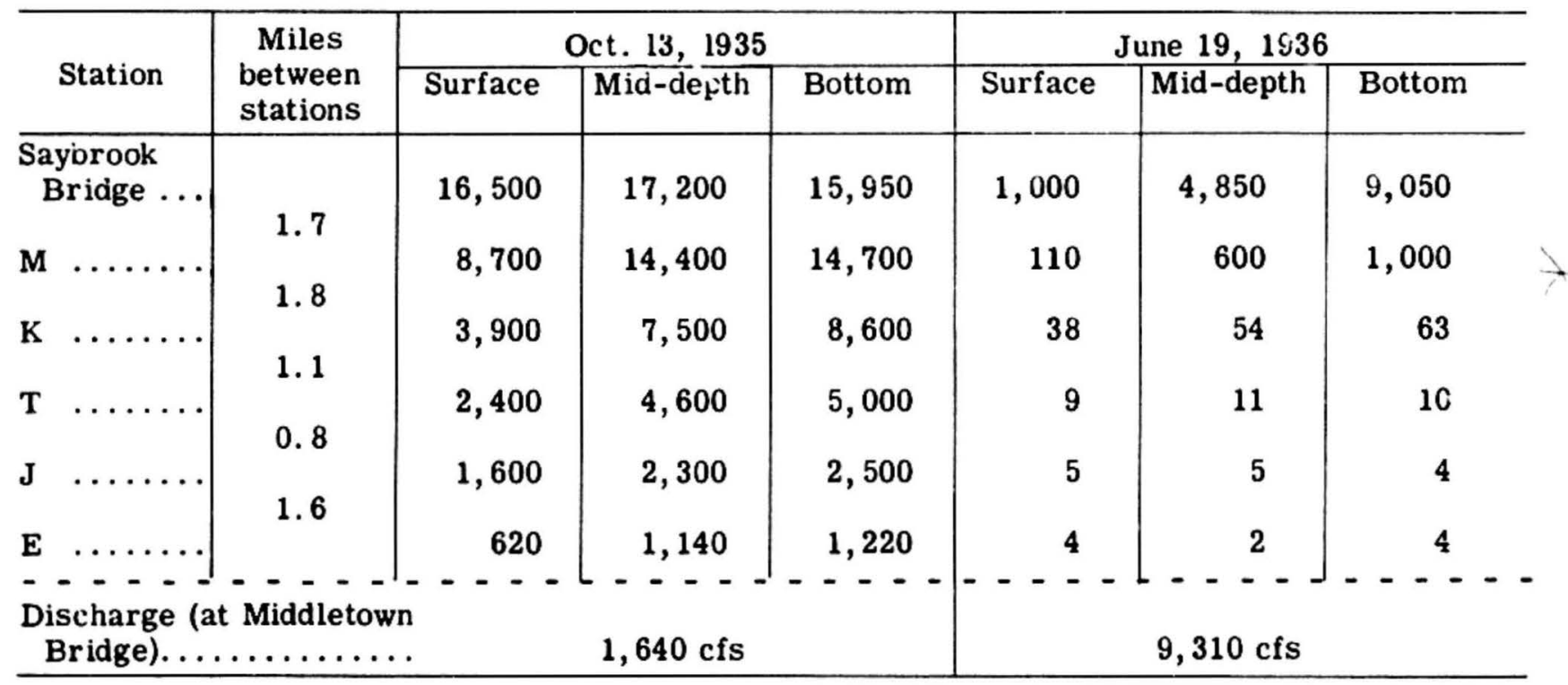

Saybrook Bridge is near Long Island Sound and the other stations are upstream in the order $M$ through $E$. On Oct. 13, 1935, there was little vertical variation in salinity at Saybrook Bridge; the salinity observed was probably close to that of the water of Long Island Sound. But upstream at stations $M$ through $E$ there was evidence of a salt-water wedge, for the surface sample was always less saline than those taken at mid-depth or near the bottom. On June 19, 1936, the greater flow of fresh water had worn away much of the wedge and at stations $\mathrm{T}$, J, and $E$ there was no longer any vertical variation in salinity. The debris of the wedge still persisted at the downstream stations, as shown by the increase in salinity from the surface to the river bottom.

A salt-water wedge is not always to be found in tidal rivers. There was none at stations $T$, $\mathrm{J}$, and $\mathrm{E}$ in the Connecticut River on June 19, 1936, although there had been an increase in salinity with depth at these same points on October 13, 1935. An ex ensive program of salinity investigation in 1929 in the Sacramento-San Joaquin Delta in California (California Dept. of Public Works, 1931, p. 198-202) showed that in many instances there was no variation of salinity with depth. No variation is to be expected when the salinity of the water is close to that of ocean water or when its salinity nears that of fresh water; the maximum variation with depth occurred when the mean chloride salinity was 10,000 to $13,000 \mathrm{ppm}$. 
Local causes. --With or without a salt-water wedge various local effects, such as tributaries or pollution, may cause cross-section variations in salinity, and these variations may be found either upstream or downstream from the source. At times ebb and flood currents take different paths resulting in a variation in the pattern of salinities at a particular cross section, depending upon whether the tide is ebbing or flooding. For example, Rhodes (1950, p. 66) found for currents in the Savannah Harbor, that

"where there is a reversal of curvature, with no straight reach of the channel or only a short reach between the ends of the curves, the paths followed by the main flood and ebb currents separate as they approach the point of reversal. The strength of the flood current tends to follow that side of the channel which has a concave shore line just seaward of the point, and the strength of the ebb currents follow that side of the channel having a concave shore line just upstream from the point. If there is a straight reach between the curves, the currents are projected into the reach in accordance with the above, but their paths through the reach are affected by its length - the longer the straight section, the more the currents are deflected from side to side by variations in channel conditions."

Where a deep pocket in a stream becomes filled with salt water, considerable time may be required io flush it out, for the fresh water may ride over the heavier salt water leaving it relatively undisturbed. This situation has been observed in the Lake Washington Ship Canal (Smith, 1927). Salt water carried upstream through the canal from Puget Sound settled in the deeper parts of the lake and remained there throughout the year.

Sampling procedure. - -In any cross section of a tidal river or estuary both lateral variations in salinity and variations with depth are to be sought for, although they may not always exist. Variations may occur at particular locations but not at adjacent upstream or downstream stations. They may occur only at some seasons or at one stage of the tide. A preliminary survey is required to find out if cross-section variations are significant. If variations with depth indicate the presence of a salt-water wedge, then lateral variations, due to Coriolis forces, are also to be looked for. Where cross-section variations seem to be the exception, rather than the rule, it may still be advisable to sample at the top, mid-depth, and bottom of the river, at the middle and from the right and left sections of the stream. A partial analysis will show whether there is any cross-section variation, and if there is, samples will then be available for complete analysis. Where cross-section variations are especially significant a more thorough sampling should be carried out. For example, in one investigation (California Dept. of Public Works, 1931) samples were taken at every 10 feet of depth and every 400 feet laterally. In order to establish the position of the sampling points full use should be made of prominent landmarks, river buoys, or other fixed objects, and in some cases of the surveyor's transit.

Top samples should be taken just below the surface, to avoid collecting oils, floating scum, and other debris. Bottom samples should be taken about 3 feet from the bottom so that mud or silt from the river bottom does not contaminate the sample.

\section{Effect of tides}

Tidal ranges. --Eecause of tidal effects the salinity at any one location may rise and fall during a tidal cycle. One may wish to discuss salinity in terms of the average during a tida' cycle, or in terms of the maximum or minimum per tidal cycle or per day. Usually the maximum is of greater interest than the minimum. The difference between the minimum and maximum chlorinities per cycle increases with the range of tide, $i . e .$, the difference between the heights of high water and low water. For example, for the two daily tides, the maximum chlorinity is greater for the higher high tide, although the average chlorinity may be the same for both tides. This is shown by the following examples, for the Delaware River at Chester, Pa., in 1949: 
Date

Aug. $6-7 \ldots \ldots \ldots$

Sept. $2-3 \ldots \ldots \ldots \ldots$

Oct. $15 \ldots \ldots \ldots \ldots$
Range of tide

in feet

6.6

5.3

5. 7

4. 7

5.0

3.8
Chloride (ppm)

Maximum

Average

358

142

143

434

817

430

1,058

805
646

643

Such an effect is to be expected. Consider the tidal river to be divided longitudinally into segments. Each segment contains more water at high tide than at low tide; the difference is referred to as the intertidal volume. On the ebb tide a volume in excess of the intertidal volume flows into the adjacent downstream segment and the remnining water is further diluted by fresh water from upstream. On the flood tide salt water from the adjacent downstream segment flows upstream, increasing the salinity as it raises the level from low tide to high tide. The difference between high water and low water, i. e., the range of the tides, controls the intertidal volume and therefore the quantity of fresh water entering the segment on the ebb tide and also the quantity of salt water entering the segment on the flood tide. Consequently, the greater the range of tide the greater range is to be expected in chloride concentrations per tidal cycle.

According to Lindner (1953), however, the average salinity per tidal cycle is more influenced by the height of the low tide. A series of high low tides alternating with high high tides will result in higher aver age salinity than a series of low low tides alternating with high high tides.

In figure 5 the daily chloride concentrations for the Delaware River at Chester, Pa., are shown for the period from July to December 1949. In the preceding 6 months the chloride concentration was generally lower and varied less from day to day. Both the average and maximum chloride concentrations for each day are plotted. The main course of this plot is controlled by the discharge rate, as will be discussed later, but variations in tidal conditions are responsible for many of the short period fluctuations. The daily tidal conditions are plotted in figure 6. That variations in the height of the lower low tide are responsible for corresponding variations in the average chloride concentration is evident upon comparing figure 6a with figure 5. (To make this comparison remove from the binding the thin-paper copy of figure 5 . Place figure 5 over figure 6 with the date coordinates matched and hold the two pages between the eye and the light so that both plots may be seen together. Move figure 5 up or down the ordinate so that those parts of figures 5 and $6 a$ being compared are close together or even overlie each other. In this manner the daily variations may readily be compared in spite of the larger long-term variation.) Figure $6 \mathrm{~b}$ gives the average daily tidal range, i. e., the sum of the two high tide elevations minus the sum of the two low tide elevations. A comparison of figure 5 with figure $6 \mathrm{~b}$ shows that salinities are influenced by the tidal range such that at a time of low tidal range there is often a small decrease in chlorinity, and conversely, when the tidal range is large the chlorinity frequently increases also. Figure $6 \mathrm{c}$ shows the mean daily tide level, i. e., onequarter the sum of the elevations of the two daily high tides and the two daily low tides. Comparing this plot with figure 5 one sees that an increase in mean tide level is often accompanied by an increase in salinity.

Tidal heights may vary without a corresponding variation in salinity. J. J. Murphy (1953) has observed that although tidal influences reach 25 miles above the mouth of the Pocomoke River in Maryland, there is a tidal variation in the salinity in only the lower 5 miles. Perhaps shoaling at the mouth of the river prevents the intrusion of a salt-water wedge; a shallow entrance to the river would result in a smaller hydraulic head to push the wedge upstream - or perhaps the salt water entering the bay is diffused through the marshland near the river's mouth instead of penetrating upstream. 


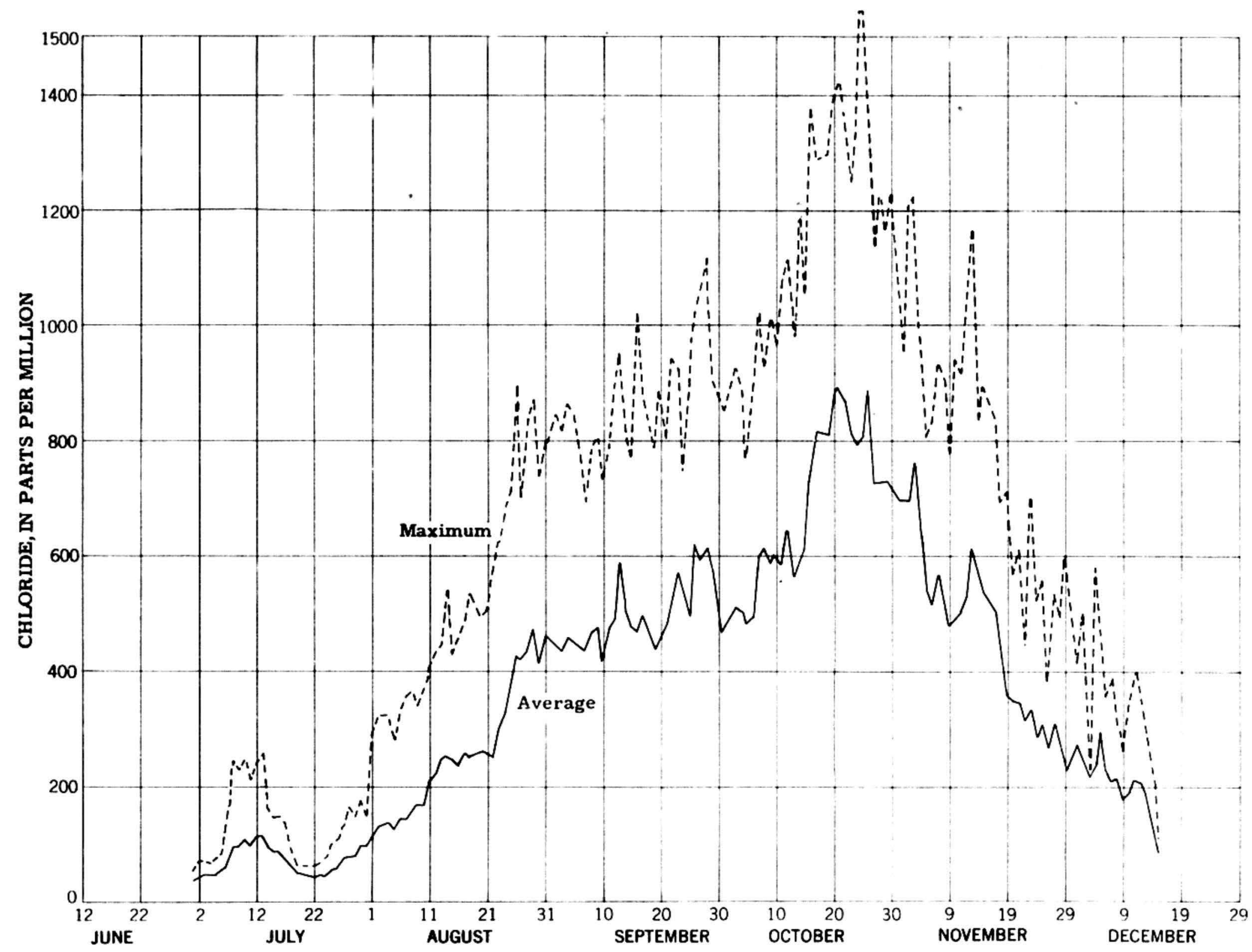

Figure 5. -- Daily chloride concentrations, Delaware River at Chester, Pennsylvania, July to December, 1949. 


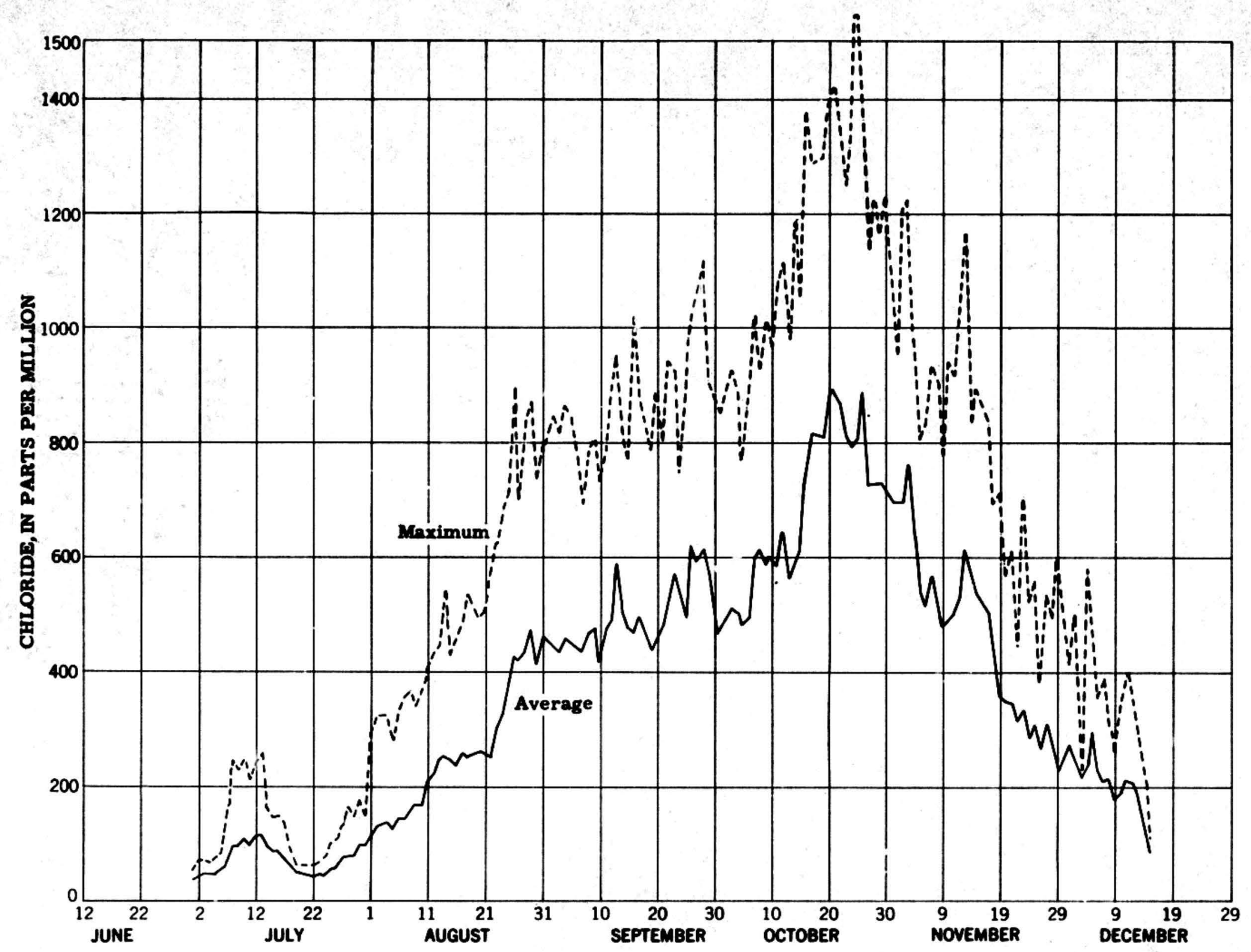

Figure 5. -- Daily chloride concentrations, Delaware Ruver at Chester, Pennsylvania, July to December, 1949. 

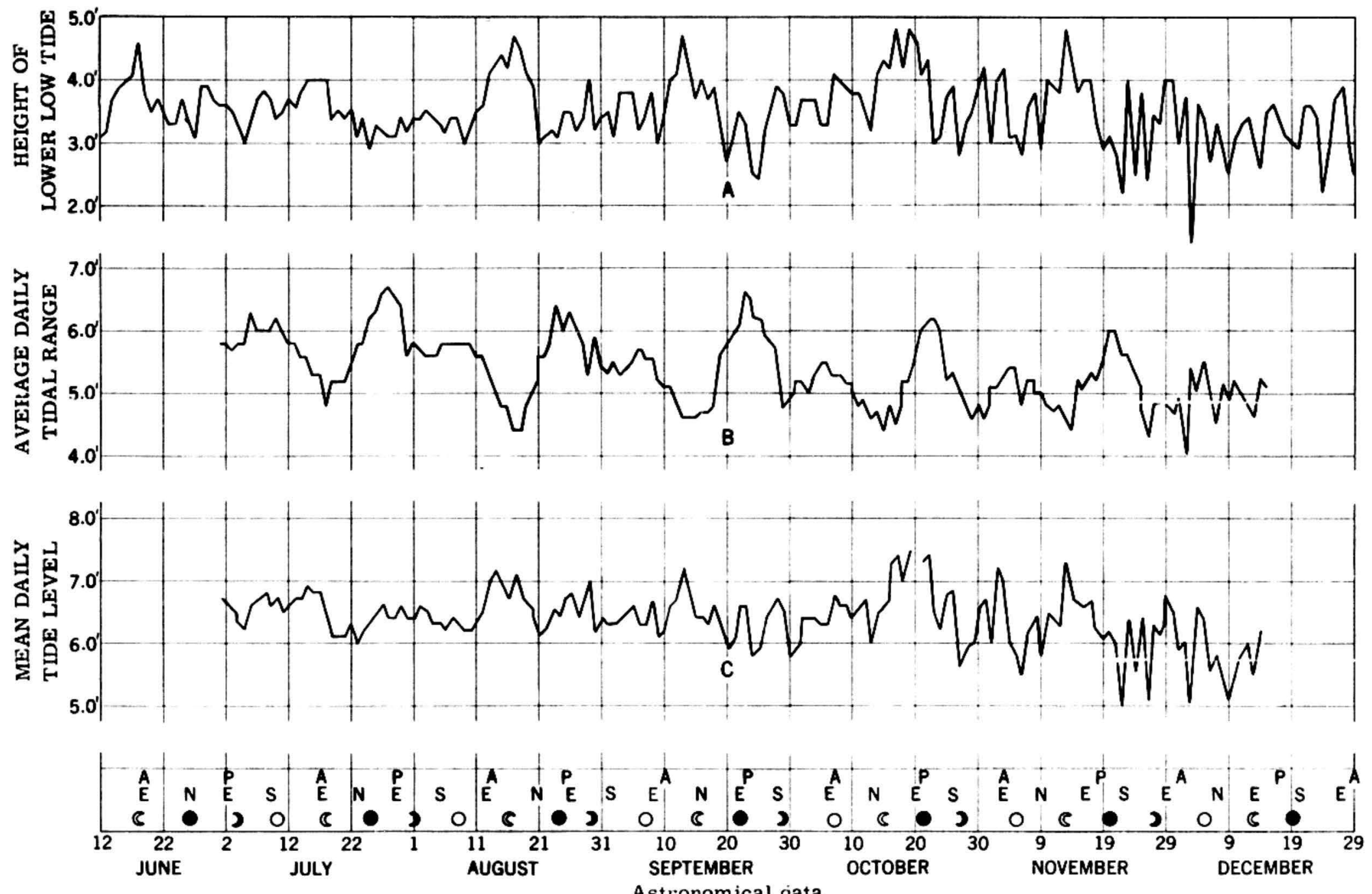

- New moon

O Full moon

$E$ Moon on the equator

N,S Moon farthest north or

A,P Moon in apogee or perigee

Figure 6. -- Daily tidal conditions: Delaware River at Chester Pennsylvania, July to December, 1949. 
Tidal stage - salinity relations. --No general relation has yet been worked out between the tidal stage of a river and the chlorinity of the water at that stage. Each river seems to be unique in this respect, and there is every reason to believe that any simple relation applicable at a given location on a river is probably not applicable at all locations on that river. Furthermore, it is probable that even for a given location on a specified river a relation that is true for a given tidal range or average salinity is not necessarily true for other tidal ranges or salinities. Nevertheless, a number of attempts have been made to obtain a relation between the chlorinity of a sample taken at a certain tidal stage and the average or maximum chlorinity for the tidal cycle.

In the report of the Delaware River Salinity Survey (Pa. Dept. of Health, 1935) are given 10 conversion diagrams which show the relation between tidal range and salinity. Each diagram applies only to a particular range of chloride concentration. Figure 7 is a copy of one of these diagrams; the solid lines apply when the chloride at the slack following high water is between 100 and $200 \mathrm{ppm}$, the dashed lines apply for chloride between 20 and $100 \mathrm{ppm}$. Tidal stages are plotted as percent of the tidal range on the ordinate axis. To illustrate, a sample taken on the ebb tide, when the tidal elevation is 2.0 feet, contains $80 \mathrm{ppm}$ chloride, and the tidal range is 5.0 feet. The tidal stage of 2.0 feet is then $2 / 5$ or 40 percent of the tidal range. Using the dashed "ebb" curve, 40 percent on the ordinate axis corresponds to 60 percent on the abscissa. The observed concentration of $80 \mathrm{ppm}$ is then 60 percent of the chloride concentration at high water slack, so that the concentration at high water slack, or the maximum chloride concentration during the tidal cycle, is $(100 / 60) \times 80$ or $133 \mathrm{ppm}$.

A report by the California Department of Public Works (1931) gives data on the variation of salinity with tidal stage for the Sacramento-San Joaquin Delta and the Upper San Francisco Bay. The hourly variations in salinity and tidal stage for 11 locations were plotted from salinity surveys made in 1929. The rate of increase of salinity with $r$ ise in tide was found to increase as the salinity increased, with a maximum effect of tidal stage on salinity at 8,000 to 11,000 ppm chloride, corresponding to about 50 percent ocean water. From these data a plot was prepared showing the relation of salinity to tidal stage (loc. cit. pl. LXII, p. 197). Figure 8 has been redrawn, with minor changes, from a portion of this plot. The ordinate is chloride concentration $1 \frac{1}{2}$ hours after any tide gage reading (in these tidal waters slack water occurs about $1 \frac{1}{2}$ hours after high water and low water). The abscissa represent mean salinity for the tidal cycle. In the family of curves each one applies to a given height of tide expressed in percent of the mean tide for the tidal cycle. Thus, for a sample of a given salinity at the appropriate chloride concentration on the or dinate axis, find the line giving the correct tidal height and read the corresponding abscissa, which is the mean salinity per tidal cycle.

A third method of showing tide-salinity relations is illustrated with the data of figure 5 on hourly chloride concentrations in the Delaware River at Chester, Pa., obtained in 1949. This method is demonstrated in figure 9 in which chloride concentration is plotted against time before and after the maximum chlorinity. In order to put all the measurements on a common basis the average chloride concentration was calculated for the period from one maximum chloride concentration to the next. This is the "average" plotted in figure 5. The ordinate of the plot is the chloride concentration expressed as a percentage of this average. The maximum plotted in figure 5 is the second of the two maxima, i. e., the one at the end of the cycle. The data are grouped by tidal range, which is the rise between the low water and high water just preceding the second maximum. During this rise in tidal stage the salt water from downstream fills the segment of the river and the magnitude of the rise determines the increase in chlorinity of the segment. Along the $x$-axis is plotted the time preceding or following the second maximum. In order to put all sampTes on the same basis the time is calculated in percent of the duration of the rising tide (low water to high water) immediately preceding the maximum, or in percent of the duration of the falling tide (high water to low water) which immediately follows the rising tide. This plot is found to be independent of discharge rate. It is dependent upon tidal range and four curves are drawn, each applying to a separate range of tidal ranges. Note that the variation from the maximum to minimum increases with increase in the tidal range. 


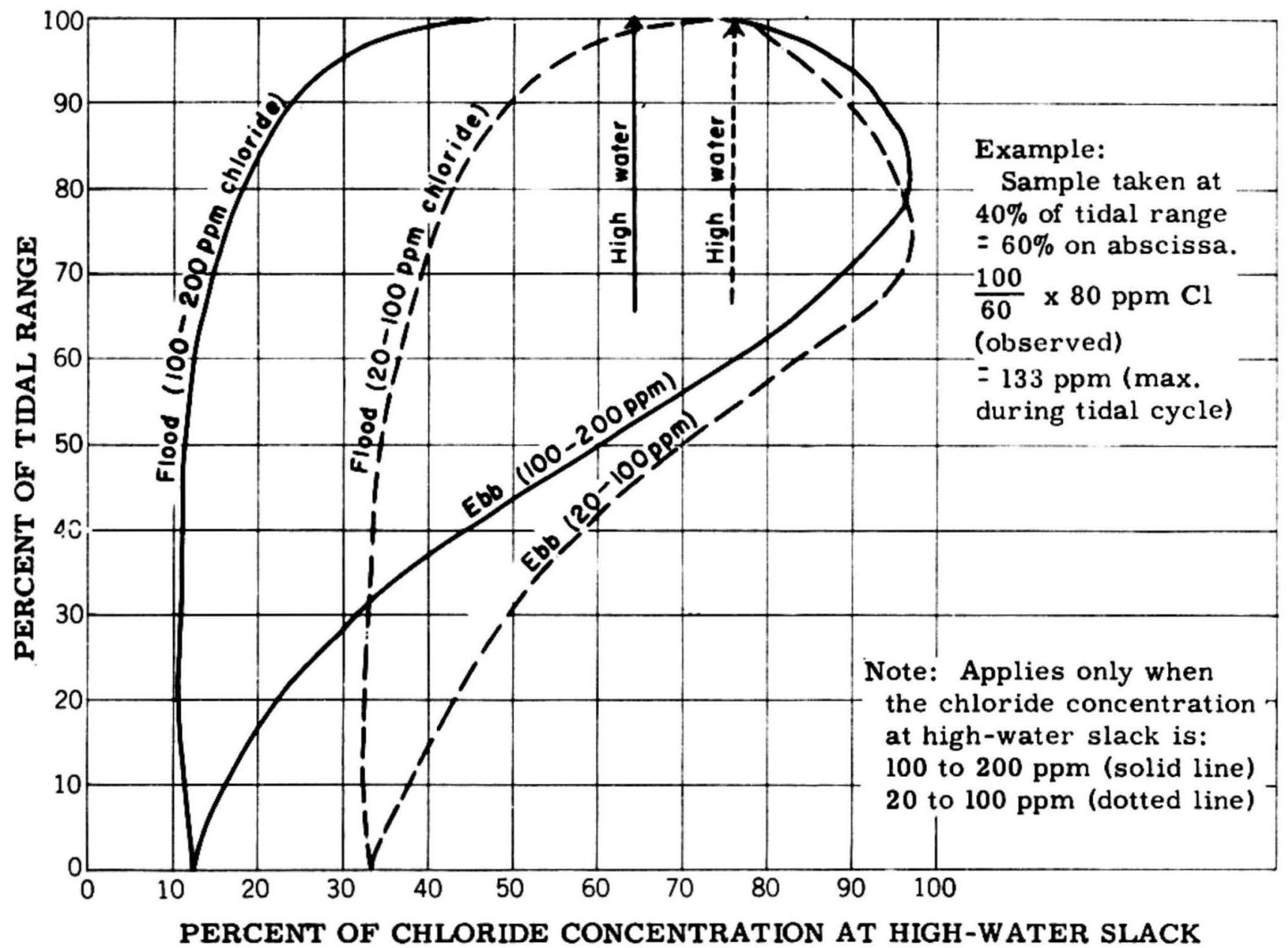

Figure 7. -- Relation of salinity to tidal stage: Delaware River, 1928-1934. From Pa. Dept. of Health (1935). 


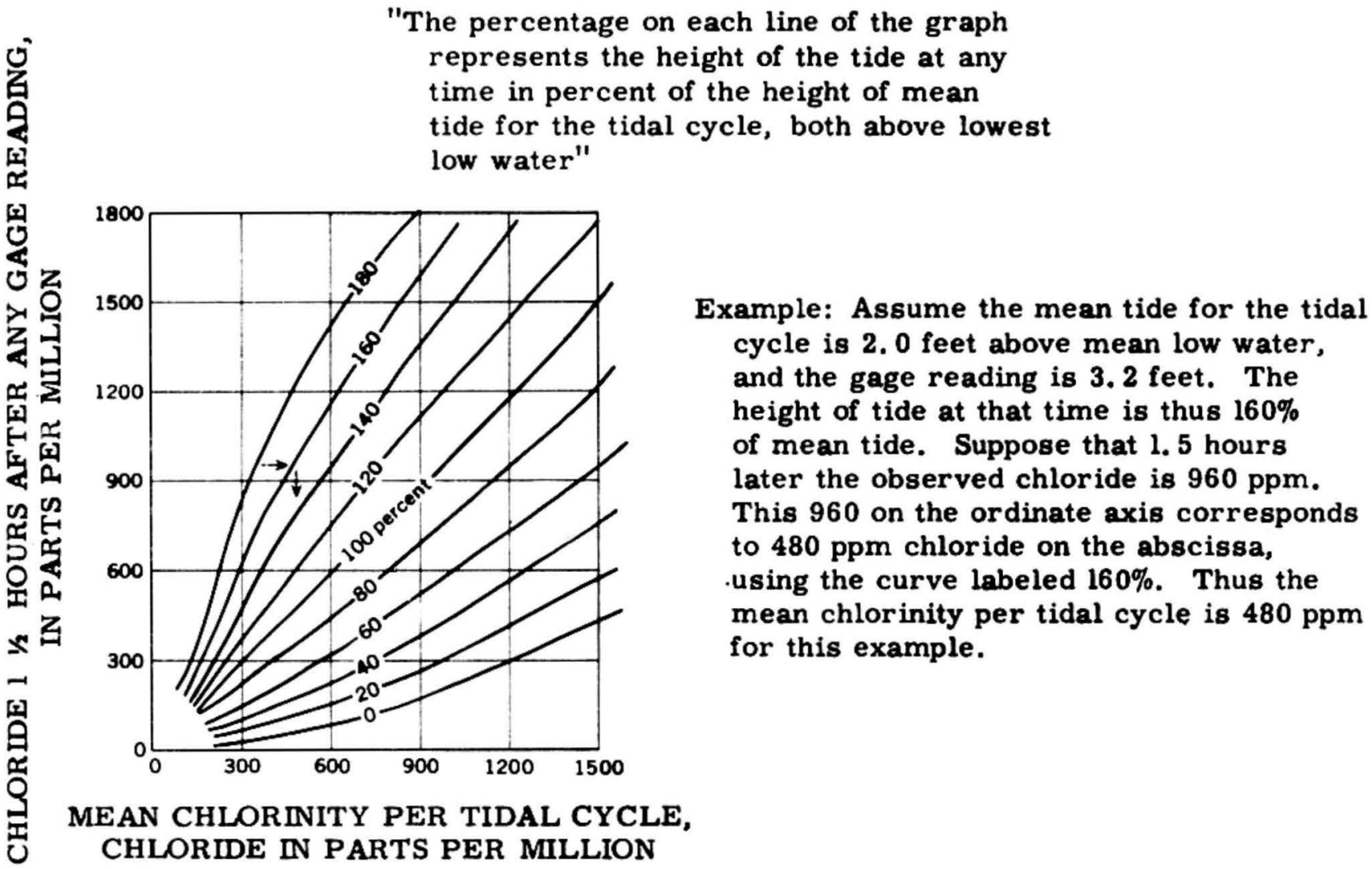

Figure 8. -- Relation of salinity to tidal stage: Sacramento - San Joaquin Delta and the Upper San Francisco Bay, May to December, 1929. Redrawn from a part of Plate LXII, p. 1'7, Calif. Dept. of Public Works (1931). 


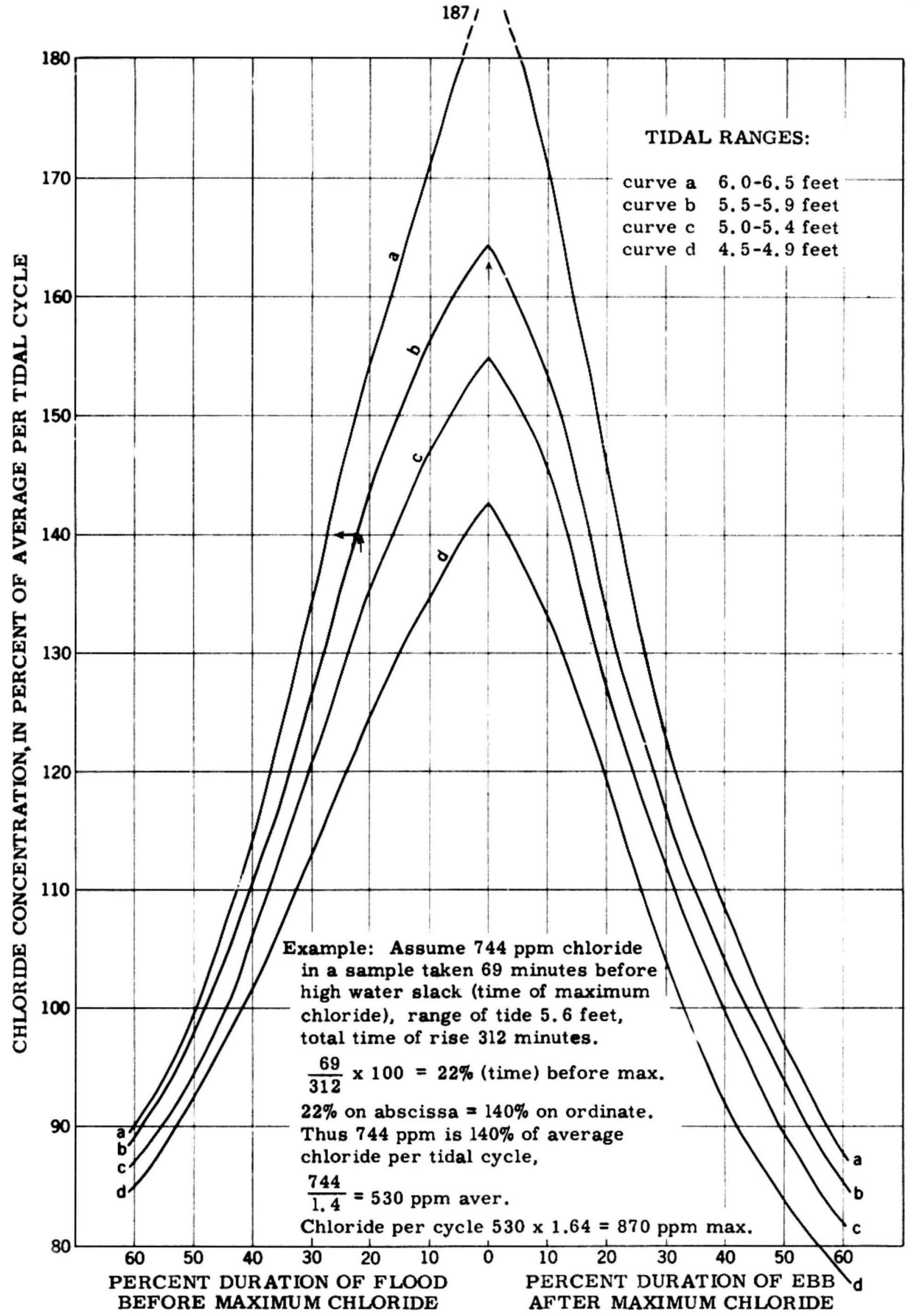

Figure 9. -- Variation in chloride concentration during tidal cycle, Delaware River at Chester, Pennsylvania, July to December, 1949. 
taken at a stated time the average and maximum chloride concentrations in the tidal cycle. From the "Current Tables" (U. S. Coast and Geodetic Survey) may be found the predicted time of the slack following high water. This may be taken as the time of maximum chlorinity. The time of sampling relative to this time is noted. From the "Tide Tables" (U. S. Coast and Geodetic Survey) is obtained the predicted heights and times of the high water immediately preceding the time of maximum chlorinity and also of the preceding low water. From these data are found the range of tide, in feet, and the duration of the rise, in hours and minutes. By determining the predicted time of the low water following the maximum chloride concentration the duration of the following tide is also obtained. Next, one calculates the time between sampling and maximum chlorinity as a percentage of the duration of the rise or fall of the tide. With this figure the plot is entered on the $x$-axis and the corresponding percent chlorinity read on the $\underline{y}$ axis, using the curve pertaining to the observed tidal range. If the observed hourly heights of tide are available, these may be plotted and the actual heights and times of high wate $:$ and the two low waters determined from the plot, with somewhat greater reliability than when the predicted values are used.

As an example of the use of these data, the average chloride concentration of samples taken at Marcus Hook, Pa., on October 1, 1951, at 12:52 p. m., was 744 ppm. Marcus Hook is sufficiently close to Chester that the plot for Chester is expected to be applicable. From the "Current Tables" for 1951 (p. 62 and 139) and the "Tide Tables" for the same year (p. 81 and 193) we find the following data for October 1, for Marcus Hook, Pa. :

\begin{tabular}{|c|c|c|}
\hline $\begin{array}{l}\text { Flood begins at } \\
\text { Ebb begins at } \\
\text { Flood begins at }\end{array}$ & $\begin{array}{r}8: 03 \\
14: 01 \\
20: 20\end{array}$ & \\
\hline $\begin{array}{l}\text { Low water, time } \\
\text { High water, time } \\
\text { Low water, time }\end{array}$ & $\left.\begin{array}{r}7: 17 \\
12: 29 \\
19: 42\end{array}\right\}$ & $\begin{array}{l}\text { Duration } 5 \mathrm{hrs} .12 . \mathrm{min} \text {. } \\
\text { Duration } 7 \mathrm{hrs} .13 \mathrm{~min} .\end{array}$ \\
\hline $\begin{array}{l}\text { Low water, height } \\
\text { High water, height } \\
\text { Low water, height }\end{array}$ & $\begin{array}{l}0.3 \\
5.9 \\
0.2\end{array}$ & $\begin{array}{l}\text { Rise } 5.6 \text { feet } \\
\text { Fall } 5.7 \text { feet }\end{array}$ \\
\hline
\end{tabular}

The sample was taken at 12:52 p. m., after high tide but 1 hour 09 minutes before high water slack, the time of maximum chlorinity. Since the rise in tide required 5 hours and 12 minutes, then:

$\left(\frac{69 \text { minutes }}{312 \text { minutes }}\right) 100=22$ percent before the maximum chloride concentration. Entering the

plot in figure 9 at 22 percent before the maximum on the time axis and using curve b, since the range of tide is 5.6 feet, we find 140 percent on the concentration axis. Thus the observed chloride concentration of $744 \mathrm{ppm}$ is 140 percent of the average. The average chloride concentration for the tidal cycle is, therefore, $744 / 1,4=530 \mathrm{ppm}$. . From the same curve the maximum is seen to be 164 percent of the average, or $530 \times 1.64=870 \mathrm{ppm}$.

It is important to realize that such plots as figures 7, 8, and 9 are only summaries of a set of observations, and that in common with any statistical data cannot be expected to always predict correct information. These curves will, however, give values for the average and maximum chloride per tidal cycle that are closer to the true values than are the analyses of spot samples taken without regard to the time of sampling.

Collection of data on tidal influences. --The river location for which information is required on the change of salinity with tidal stage may lie in the seaward, the upriver, or the intermediate part of the tidal river. In the upriver part mixing will probably be good and the cross section uniform; then sampling at any convenient point in the main current will probably be adequate. However, in this part of the river the chloride content will be relatively low (e. g., less than $100 \mathrm{ppm}$ ), variations with the tidal stage small in magnitude and of minor interest. In the intermediate zone stratification is likely so that the depth of sampling becomes important. A 
study of tidal effects in this segment of the river would require sampling at least at the surface and bottom of the river, preferably at other depths as well. Since the stratification pattern may differ with the ebb and flood tides some check is required to find whether the tidal cycle variation is the same on the right and left sides as in the center of the river. A similar situation exists in the seaward zone except for its extreme seaward portion where stratification has disappeared. There the salinity will be nearly that of sea water and the tidal cycle variations small. Because of the high salinity water quality investigations are of less widespread interest than in the fresher portions of the river. (They are of interest to shellfish culture and in the manufacture of bromine from sea water, to name two exceptions.)

Thus the rise and fall of chlorinity with the stage of the tide will be most pronounced in that portion of the river intermediate between its seaward and upriver parts. It is, however, necessary to remember that the intermediate part is not geographically fixed but moves up and down the river with changes in the discharge rate, sea level, and other factors. Thus a location on the river in the intermediate part at one time of vear may be in the upriver or seaward part at another time.

To establish such relations as represented in figures 7,8 , and 9 requires a considerable number of chloride determinations. As many as 15 samples, taken at hourly intervals, are required in a single tidal cycle. A large number of tidal cycles must be sampled. For example, for figure 9, some 15 to 20 tidal cycles in each of the four tidal ranges represents the minimum sampling. In addition, the sampling should include a range of discharge rates, average salinities, and others to determine whether any of these factors influence the tidal cycle behavior.

Even to obtain the average salinity of a single tidal cycle it is necessary to take a number of samples over the complete tidal cycle. Where the sampling program must be on a more modest scale one may have to be satisfied with determining only the maximum salinity. In theory this can be obtained by taking a single sample at high-water slack, but in view of the difficulty in predicting or observing this time precisely it will be better to also sample 30 minutes before and $\mathbf{3 0}$ minutes after the predicted time of high-water slack to assure that the time of high-water slack is included in the sampling period.

The maximum salinity, obtained by sampling at high-water slack, is of greater value than the minimum, which could be obtained by sampling at low-water slack. The average salinity, however, cannot be obtained by sampling only at high-water slack, nor can it be obtained by averaging the analyses at high and low slack water. Another reason for sampling at slack water is that while the tidal current is flowing, e. g., mid-tide, there are large variations in current velocities at different depths, consequently the chloride concentrations are likely to vary in an erratic manner.

\section{Changes in Sea Level}

Mean sea level changes slowly over a period of years, as Marmer (1949) has reported. The mean sea level on the Atlantic Coast of the United States rose at a rate of approximately 0.02 feet per year from 1930 to 1947 , for example, and at a somewhat lower rate on the Pacific Coast. Daily fluctuations in sea level may also arise from winds piling up water against the shore, from changes in barometric pressure, and from changes in density of the water near the shore. An increase in sea level adds to the hydraulic head forcing ocean water upstream and a decrease in sea level has the opposite effect. Data on the daily fluctuations of sea level at the mouth of a river are not usually available, but the closely related "mean tide level" or "mean river level"for any day are easily obtained. The mean tide level is the average of mean high water and mean low water. The mean tide level may be predicted from the predicted heights of tides published annually in "Tide Tables." The mean river level may be calculated from the hourly heights of tides, such as observed by the U. S. Coast and Geodetic Survey. The average of the hourly heights for 24 hours is the mean river level.

The mean daily tide level for the Delaware River at Chester, Pa., is plotted in figure 6c. 
Changes in the mean tide level have a corresponding effect on chloride concentration, and explain much of the detail of figure 5, especially in the plot of maximum chloride. An increase in sea level, as shown by an increase in mean tide level, results in a corresponding increase in chlorinity of the tidal river. While the effect is small it appears to be immediate and to be independent of other fluctuations. In almost every case the peaks or troughs in the mean tide level curve (fig. 6c) are matched by corresponding peaks and troughs in the maximum chloride concentration plot (fig. 5). Note, for example, the three peaks between suly 8 and 15 , the four between July 27 and August 8 , and the two on August 14 and 18, which are found on figures 5 and $6 \mathrm{c}$. Where the normal tidal range is small the variation in salinity of the river water due to changes in sea level may be a more significant factor than at present realized.

\section{Effect of Discharge Rate}

Meshanism. --The mechanism by which discharge rate affects salinity may be explained in simple terms. Suppose A, B, and C are three locations in downstream order on the river sosituated that the river capacity from $A$ to $B$ is equal to the river capacity from $B$ to $C$. The chloride concentrations are $20 \mathrm{ppm}$ at $\mathrm{A}, 50 \mathrm{ppm}$ at $\mathrm{B}$, and $150 \mathrm{ppm}$ at $C$. If fresh water containing $5 \mathrm{ppm}$ chloride, sufficient in quantity to fill the river bed from $A$ to $B$ flows into the river at $A$ it will push the more saline waters ahead of it and the chloride concentrations should become $5 \mathrm{ppm}$ at $\mathrm{A}, 20 \mathrm{ppm}$ at $\mathrm{B}$, and $50 \mathrm{ppm}$ at $\mathrm{C}$. However, tidal action is continually bringing salt water upstream at a rate increasing as the mean tide level increases and as the tidal range increases. Therefore, the flushing effect of fresh water discharge is opposed by salinifying effect of tidal action. For a specified salinity at a particular location on the river there is a discharge rate at which the salinity neither increases nor decreases from day to day until there is a change in the discharge rate, the tidal range, or the mean tide level.

Actually this is an oversimplification. The ebb and flood of the tide mixes the fresh and salt water so that more salt is carried upstream than would be assumed from the simple mechanism given above. Furthermore, at some point in the river there is the tip or upriver extremity of a salt-water wedge or at least an intermediate region between the salty seaward part and the fresher upriver part. The tip of the salt-water wedge is eroded by the downstream flow of fresh water. As the discharge rate of fresh water increases, the turbulence also increases and will erode the salt-water wedge, so that at the higher discharge rates the wedge will be worn away and the saltier water will recede downstream.

Second-order effects. --The general effects of discharge rate on salinity in tidal streams are therefore clear. High flow rates bring low salinity, but as the discharge rate falls the salinity front moves upstream, so that for any specified location a decrease in the rate of flow causes an increase in the salinity. In addition to these general trends there are second-order effects to be considered. In certain instances an increase in discharge rate is accompanied by a brief increase in conductivity or salinity. This may be due to channel scour, or the flushing of pools of pollution or concentrated waters that have accumulated at low river stage. The increase in conductivity is observed in the first few hours of increased flow and vanishes in less than a day. The tidal range and sea level also influence the salinity and these effects are superimposed on the effects of change in the discharge rate. In the interests of simplicity, but at the sacrifice of precision, it is sometimes expedient to ignore second-order effects and to consider only the effect of discharge rate on the salinity.

Time-series plots. --One method of showing a correlation between discharge rate and chlorinity is to plot both as time series on the same time scale. Figure 5 , for example, shows the maximum and average daily chloride concentration of the Delaware River at Chester, $\mathrm{Pa}$. , from July to December 1949. Figure 10 shows the daily mean discharge rates for the Delaware River at Trenton, N. J., for the same period. A comparison of the two curves shows the influence of discharge rate on chlorinity. In January to June of 1949 the chloride concentration rarely, if at any time, exceeded $50 \mathrm{ppm}$, and the discharge rate as measured at Trenton, N.J., exceeded 8,500 cfs every day until June 6, when it began to decrease, setting the stage for the higher chlorinities shown in figure 3 . The decrease in discharge rate from June to mid- 


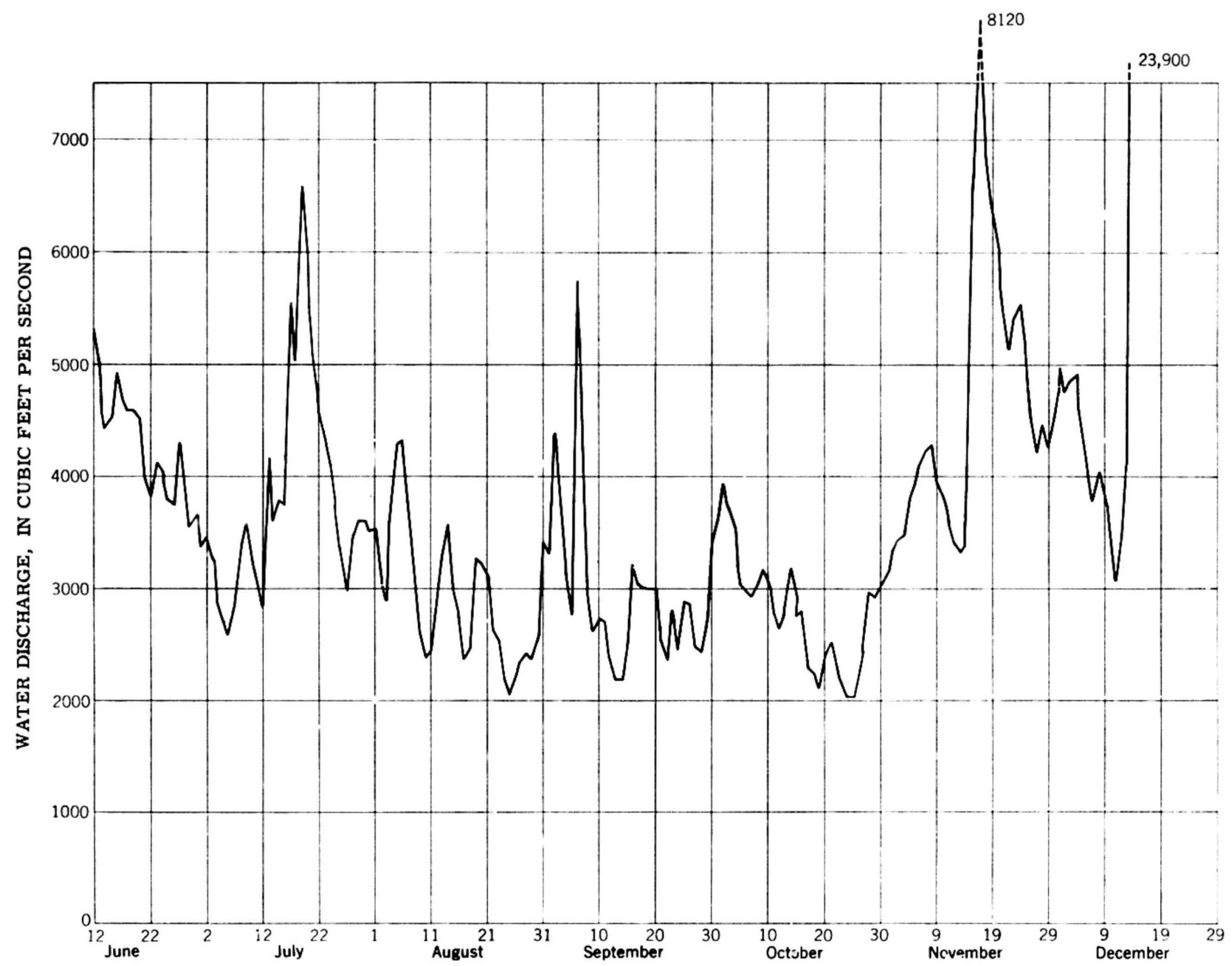

Figure 10. -- Daily mean water discharge, Delaware River at Trenton, New Jersey, June to December 1949. 
October is accompanied by a rise in salinity, and the upward trend in discharge rate during the next 2 months is accompanied by a downward trend in salinity. Moreover, even periods of temporary high flow (July 15-21, September 1-7, September 30-October 4, November 15-26) show their effect in reducing salinity or in decreasing its rate of advance, and short periods of reduced flow bring about an increase in salinity (July 1-7, July 25-August 3, August 21-26, October 14-25, November 8-13).

Smoothed curves. --The curve of daily chloride concentration is well serrated, reflecting many minor or short-period fluctuations in chloride concentration. Some of these are due to fluctuations in sea level; some may be due to changes in tidal range, to short-period fluctuations in discharge rate, or to other second order short-term factors. For some purposes it may be desirable to smooth out these small fluctuations in order to center attention on the major factors. This has been done in figure 11 , in which the data of figure 5 on daily chloride concentration have been "smoothed" and plotted on the same time scale as figures 5 and 10. There are several ways of smoothing such data. In figure 11 a weighted moving average has been calculated. If $c$ is the chloride concentration on the day plotted and $a, b, d, e$ are the concentrations on the two days preceding and the two days following, then:

$$
\frac{a+2 b+4 c+2 d+e}{10} \text { gives the weighted chloride concentration plotted. By this device }
$$

figure 11 represents the general trend of daily chloride concentrations with temporary and minor fluctuations repressed. The discharge data of figure 10 might also profitably be plotted as a weighted moving average.

Logarithmic scales. --To show the variation in mineral content of the Saline River with changes in stream flow, Durum (1953) plotted specific conductance and mean daily runoff against the date, as shown in figure 12, redrawn from a figure used by Durum (1953, fig. 4). These curves show that a period of high specific conductance (high salinity) of the water is concurrent with a low discharge rate and that a high rate of discharge results in a decrease in salinity. In this figure the ordinate is logarithmic, a device which accentuates the effect of low flow rates.

Tabular presentation. --The effect of discharge rate on salinity may be shown by tabular, as well as by graphic, presentation of the data. This is illustrated by table 6 in which are presented some data on chloride concentration in the Combahee River, South Carolina. These data were supplied by F. H. Pauszek, Quality of Water Branch.

Table 6. --The effect of discharge rate on salinity: Combahee River, South Carolina; chloride concentrations, in parts per million

\begin{tabular}{|c|c|c|c|c|c|c|}
\hline \multirow{2}{*}{$\begin{array}{l}\text { Date ........ } \\
\text { Discharge .... } \\
\text { Tide ........ }\end{array}$} & \multicolumn{2}{|c|}{$\begin{array}{l}\text { Oct. 2, } 1951 \\
172 \mathrm{cfs}\end{array}$} & \multicolumn{2}{|c|}{$\begin{array}{c}\text { Dec. } 11-12,1951 \\
343-351 \mathrm{cfs}\end{array}$} & \multicolumn{2}{|c|}{$\begin{array}{c}\text { Mar. 25-26, } 1952 \\
1,180-1,270 \mathrm{cfs}\end{array}$} \\
\hline & High & Low & High (11th) & Low (12th) & High (25th) & Low (26th) \\
\hline Location & \multicolumn{6}{|c|}{ Chloride concentration, in parts per million } \\
\hline $\begin{array}{l}4 \ldots \ldots \ldots \ldots \\
5 \ldots \ldots \ldots \ldots \\
6 \ldots \ldots \ldots\end{array}$ & $\begin{array}{r}4,380 \\
1,660 \\
645\end{array}$ & $\begin{array}{r}1,120 \\
565 \\
157\end{array}$ & $\begin{array}{l}490 \\
290 \\
132\end{array}$ & $\begin{array}{l}81 \\
30 \\
13\end{array}$ & $\begin{array}{r}24 \\
17 \\
9.5\end{array}$ & $\begin{array}{l}8.0 \\
8.0 \\
7.0\end{array}$ \\
\hline $\begin{array}{l}7 \ldots \ldots \ldots \ldots \\
8 \ldots \ldots \ldots \ldots \\
9 \ldots \ldots \ldots \ldots\end{array}$ & $\begin{array}{r}148 \\
25 \\
7.0\end{array}$ & $\begin{array}{r}40 \\
7.2 \\
5.5\end{array}$ & $\begin{array}{r}18 \\
8.2 \\
7.2\end{array}$ & $\begin{array}{l}7.5 \\
7.2 \\
7.2\end{array}$ & $\begin{array}{l}8.0 \\
7.2 \\
7.2\end{array}$ & $\begin{array}{l}6.5 \\
6.2 \\
6.5\end{array}$ \\
\hline $\begin{array}{l}10 \ldots \ldots \ldots \ldots \\
11 \ldots \ldots \ldots \ldots \\
12 \ldots \ldots \ldots \ldots\end{array}$ & $\begin{array}{l}6.0 \\
6.2 \\
6.2\end{array}$ & $\begin{array}{r}5.0 \\
-- \\
--\end{array}$ & $\begin{array}{l}6.6 \\
7.5 \\
6.8\end{array}$ & $\begin{array}{l}7.0 \\
6.5 \\
7.0\end{array}$ & $\begin{array}{l}8.0 \\
7.0 \\
6.5\end{array}$ & $\begin{array}{l}6.5 \\
6.5 \\
6.5\end{array}$ \\
\hline
\end{tabular}




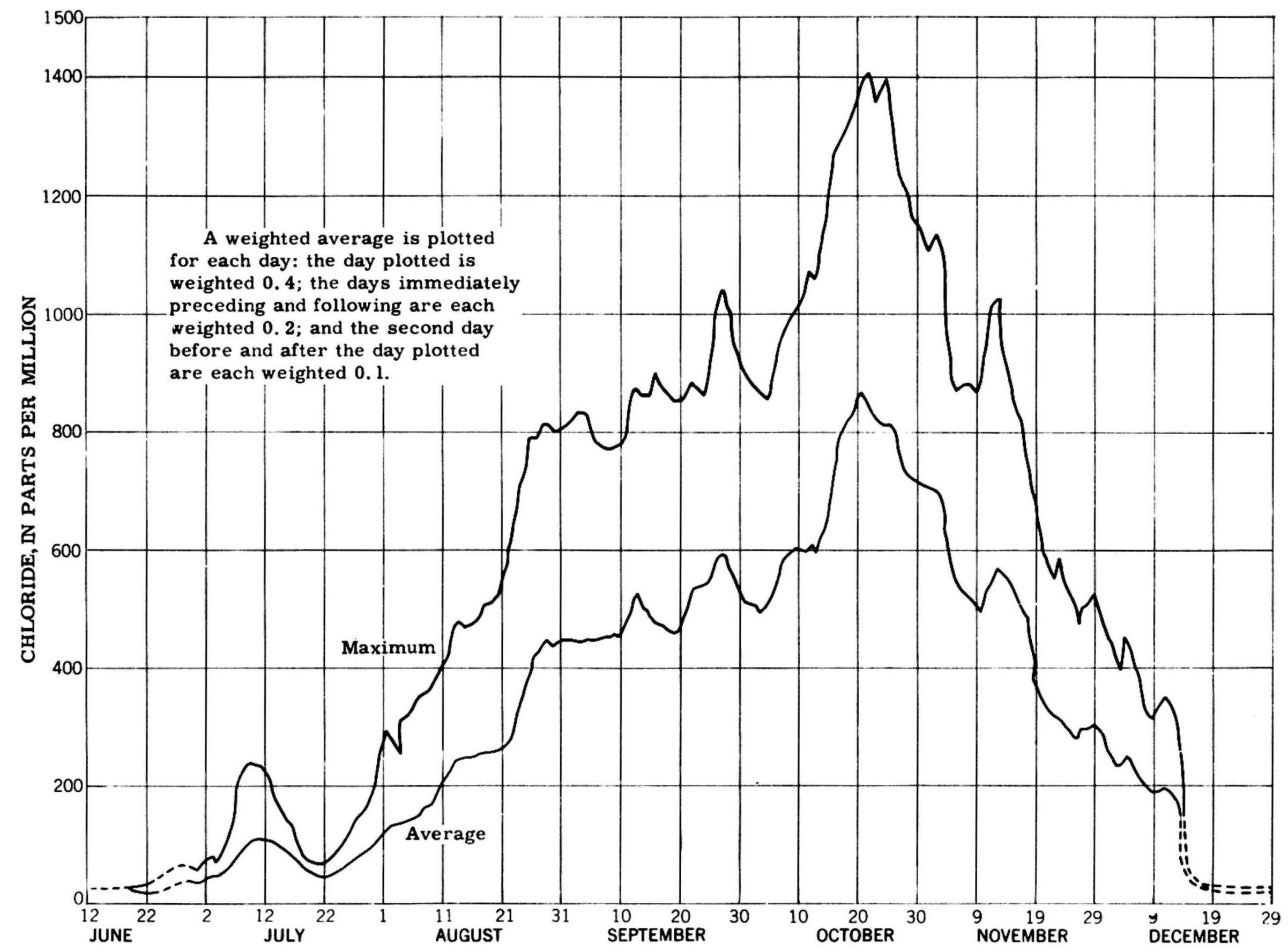

Figure 11. -- Chloride concentrations, (smoothed curve), Delaware River at Chester, Pennsylvania, June to December, 1949. 


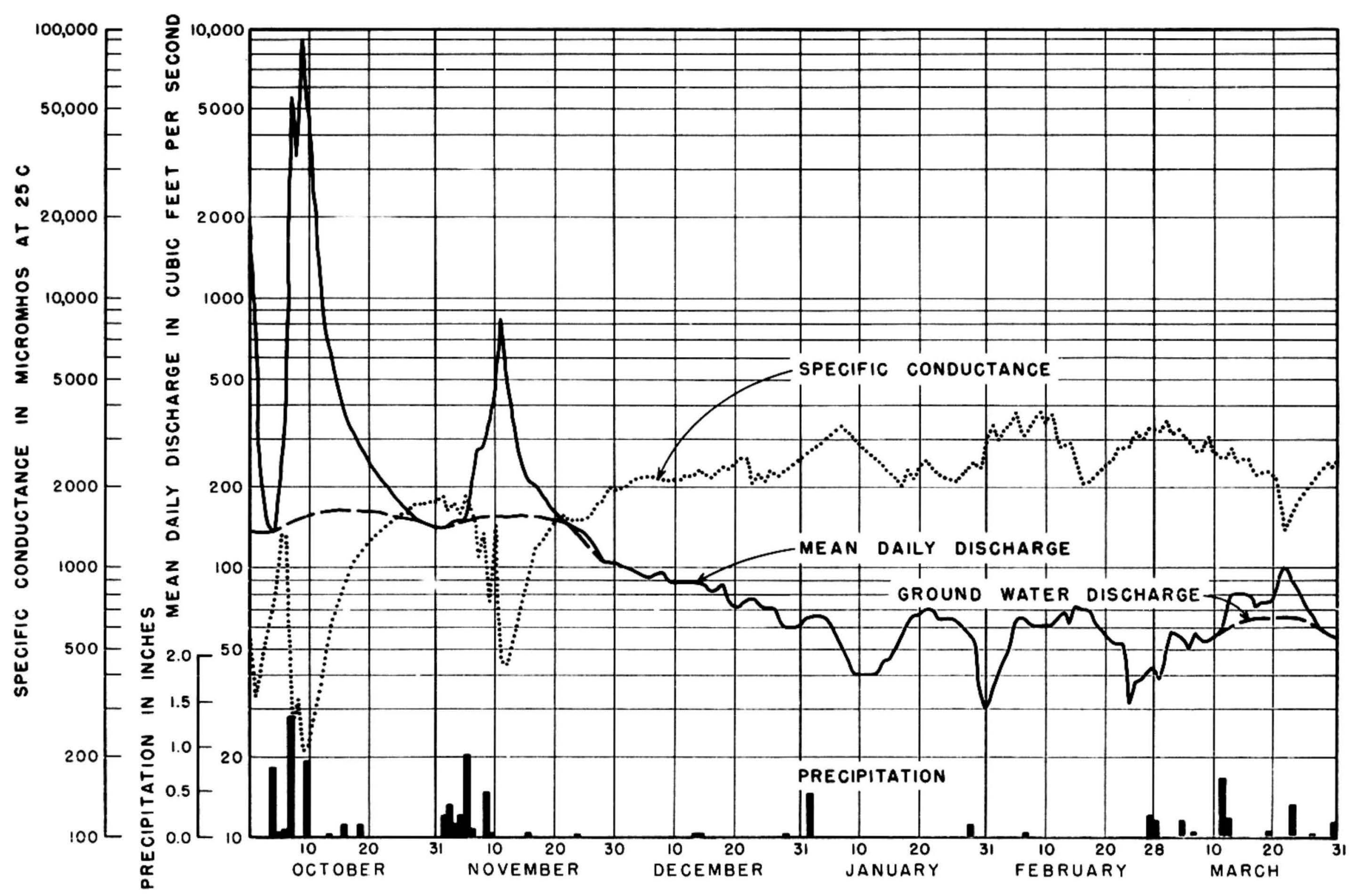

Figure 12. -- Relation of specific conductance to mean daily runoff, Saline River near Russell, Kansas, October 1947 to March 1948. Redrawn from Figure 4, Durum (1953). 
From this table it is evident that, at stations 4 to 7 , the chloride content decreases as the discharge increases. It is clear also that the $25 \mathrm{ppm}$ isochlor moves downstream from station 8 at discharge $172 \mathrm{cfs}$ to station 7 at discharge $343-351 \mathrm{cfs}$ and to station 4 at discharge 1, 180-1, 270 cfs. Such a tabulation of data, together with a map of station locations, and columns arranged in order of increasing discharge rate, displays considerable information about saltwater intrusion. They are the basic data for determining the rate of salt-water intrusion or retreat.

Position of isoquality lines. --A further method for showing the advance or retreat of salinity is to observe the daily location in the river of a particular concentration of chloride, e. g. , $50 \mathrm{ppm}$, or of a particular specific conductance, e. g. , 200 micromhos, or of some other measure of water quality, such as a particular concentration of dissolved solids. As salt water intrudes into or retreats from the river the longitudinal location of, e. g., specific conductance 200 micromhos, or of the 50 parts per million isochlor changes, also. Thus, salt-water intrusion may be shown by noting the daily position on the river of conductivity 200 , or of any other conductivity or chloride concentration indicative of salt-water intrusion. (See figs. 1, 2).

For example, Lamar (1940) made daily measurements of specific conductance at nine sampling stations on the Savannah River near Savannah, Ga. From these measurements he estimated the daily position of conductivity 200 micromhos. These positions are plotted in terms of thousands of feet downstream from an arbitrary datum point. Lamar selected periods of time covering variations of the tidal-range cycle and for each period found the aver: discharge and the average position of conductivity 200 micromhos. The result of plotting these average positions of conductivity 200 micromhos against the average discharge for the same period is shown in figure 13 (redrawn from Lamar's figure 7). From this figure it is seen that at the downstream stations, where the effect of tidal action is more pronounced, a greater flow rate is required to prevent the advancement of salinity.

A variant to this approach is to use two kinds of symbols in plotting the location of conductivity $\mathbf{2 0 0}$ (or some other conductivity level or isochlor) against the discharge rate on the day of sampling; one symbol is used if the isoconductivity line or isochlor is advancing upstream, another symbol if it is retreating. It is also helpful to indicate the rate of advance or retreat for each point plotted. The equilibrium curve is then drawn to separate the areas on the plot occupied by the two kinds of symbols and therefore represents the conditions under which the isochlor neither advances nor retreats.

Mason and Pietsch (1940) have worked out a diagram applicable to the Delaware River that permits the calculation of the displacement of a given isochlor up or down river from the average runoff over the period under consideration. The method of constructing this diagram is complex and the original paper should be consulted. In their approach to the problem attention is centered on the volume of fresh water between the head of tide and isochlor 50. A portion of this volume, which they call the "absorption volume" is absorbed by the brackish water each day through tidai mixing. If the stream flow above the isochlor is equal to the absorption volume, the isochlor remains stationary; if the stream flow exceeds the absorption volume, the isochlor retreats; if the stream flow is less than the absorption volume the isochlor advances upstream. In addition to a day-to-day plot of the position of the isochlor, river capacities and cross-sectional areas and discharge rates are required for the calculations. The results of their calculations are summarized in a chart (Mason, 1940, p. 462, fig. 6) from which may be read the discharge rate required to maintain a given chlorinity at any sampling station on the Delaware River, and how far any isochlor will retreat or advance in a given number of days when the average streamflow is known.

Sampling stations. --The first requisite for determining the effect of discharge rate on salinity is a gaging station to measure the inflow of fresh water into the tidal river. This gaging station should be far enough upstream to be above any tidal effects. It could, for example, be upstream from the first dam. One must consider how accurately the discharge at the gaging station represents the flow of fresh water into the tidal portions of the river. Is there significant additional inflow of fresh water below the gaging station from tributaries, surface runoff, 


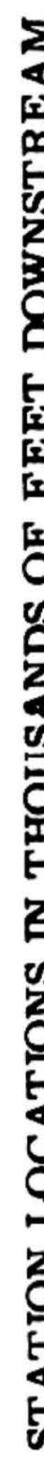

息

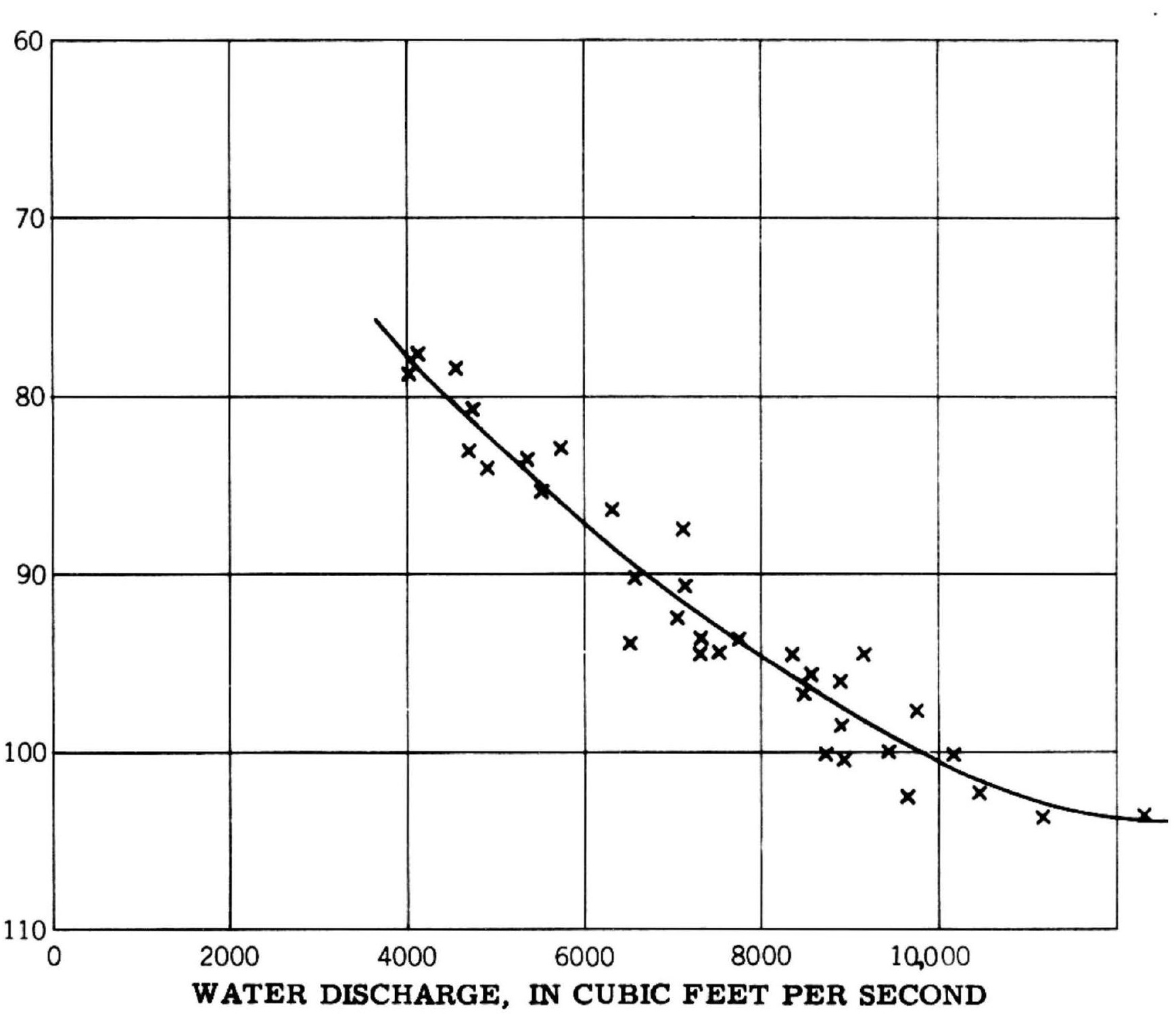

Figure 13. -- Position of conductivity 200 micromhos as related to stream flow: Lower Savannah River, Georgia 
or ground-water seepage? Does the quantity of this additional inflow vary in the same way as the discharge at the gaging station?

There should be a water-quality sampling station above the tidal reaches of the river (preferably at or near the gaging station) to establish the character of the fresh-water inflow to the river. In addition, there should be a number of sampling stations in the lower river for the purpose of measuring salt-water intrusion. The number and location of these sampling stations will depend upon local conditions, but should embrace the intermediate portion of the river, i. e., the tip of the salt-water wedge and the adjacent upstream and downstream regions. The geographical location of the intermediate zone varies with the river-flow and exploratory sampling at high and low flow will probably be necessary to establish the location of the sampling stations. In the studies of the Connecticut River, the Combahee River, and the Savannah River, previously cited, there were from 9 to 21 sampling stations on each river. The average interval between stations was from 0.75 to 2 miles.

\section{Loss or Gain of Ground Water}

Streams at a lower level than the water table may receive water by percolation from the ground-water aquifers, and those flowing above the water table may recharge ground-water reservoirs. Streams of the first kind are said to be effluent, those of the second kind influent, if there is actually a flow of water between the stream and the aquifer. The occurrence of effluent or influent seepage depends partly upon the condition of the stream bed; if heavily silted or coated with precipitated material it may be rendered impervious or "insulated." If a flow does occur, its rate depends upon the hydraulic head and the transmissibility of the aquifer. The evaluation of seepage is required for river-flow forecasting, for in many cases effluent seepage maintains stream flow long after rainfall has ceased. Information on the amount of seepage is obtained from such measurements as stream gaging at two stations to determine the loss or gain to the stream between the gaging stations, pumping tests on adjacent wells, mapping piezometric surfaces, changes in the chemical composition or temperature of surface water or well water that might indicate a mixing of the two.

With tidal rivers special problems arise in demonstrating seepage through the river bed: the difficulty of gaging stream flow when the stream velocity fluctuates - and reverses - with the ebb and flood of the tide, changes in hydrostatic head accompanying changes in tide level, variations in salinity with the rise and fall of the tide. Portions of the stream may be temporarily sealed off by silt or deposited materials formed as a result of mixing sea water and fresh water or shifted by the mechanical action of the tides. Floods may scour the river bed and transfer the material to a new location, dredging may remove some of it from the river or set up new currents which scour a portion of the channel previously sealed off. It is clear that the investigation of this problem with respect to tidal rivers will require unusual caution and judgment based on a knowledge of local geologic and hydrologic conditions.

Indentification of mixtures. --In some cases it may be suspected that a given water sample is a mixture of two other waters, as the water in the saline portion of a tidal river may be a mixture of upland water and ocean water. For example, seepage from a river into an adjacent ground-water aquifer would be suspected if it were shown that the composition of water from a heavily-pumped well near the river bank were intermediate in composition between that of river water and of the ground water moving toward the well at some distance from the river bank. The problem is discussed in detail by Langelier and Ludwig (1942, in particular on pages 348-351). They discuss methods of classifying waters with respect to the mineral content but independent of their concentration. R. A. Hill's method of plotting water analyses on trilinear paper (Langelier, 1942) or the similar method of A. M. Piper (1944) should be useful in the problem of mixtures. W. F. Langelier (1942) describes a rectangular diagram which can also be used for this purpose. The equivalents of $\mathrm{Na}+\mathrm{K}$, as a percentage of the total equivalents of cations, are plotted against the equivalents of $\mathrm{SO}_{4}+\mathrm{Cl}+\mathrm{NO}_{3}+\mathrm{F}$, as a percentage of the total e quivalents of anions. Water samples with dissoived solids of similar composition fall in the same area of the diagram, irrespective of their concentration. If two water samples are mixed, 
the composition of the mixture on the diagram falls on a straight line between points representing the composition of the two samples before mixing.

Typical Delaware River water at Morrisville, Pa. (not far from the head of tide) is plotted on figure 14 at point "IA," ocean water at " 5 ." The points numbered "2" represent the composition of Delaware River water about 20 miles downstream, at Bristol, Pa. , those numbered "3" represent Vine Street, Philadelphia, another 20 miles downstream, and those numbered "4" Marcus Hook, Pa., which is 20 miles below Vine Street. Point "6A" represent an average composition of Schuylkill River water; the Schuylkill River flows into the Delaware between Vine Street and Marcus Hook and contributes probably less than one-fifth of the average Delaware River flow below the confluence. It is to be noted that the points " 2, " " 3 , " and " 4 " are intermediate between "1" and "6," showing that the water in the Delaware is primarily a mixture of fresh water from above Morrisville with ocean water. At Marcus Hook, at low flow, the river water has nearly the same composition as ocean water (as shown by the proximity of points " $4 \mathrm{~L}$ " and " 5 ") although the concentration of dissolved salts is only one-tenth as great. The relative concentration of water samples may be shown on these diagrams by circles of an area proportional to the total equivalent concentration of dissolved salts. Circles have been drawn about points " 5 " and " $4 \mathrm{L"}$ only. The scale for drawing these circles is shown in the bottom right-hand corner of figure 14. The lower scale is constructed from the upper one by halving the number on the upper scale, squaring, and multiplying the result by an appropriate power of ten, so that the circle size fits the diagram. In figure 14 note that at low flow the water composition at stations " 3 " and " 4 " approaches more closely the composition of ocean water than at average or high flow.

Some caution is required in applying the same technique to mixtures of which ground water is a component, for sometimes a change in the chemical composition of the water occurs as it percolates through the ground. For example, ion-exchange (either cation or anion) may take place, sulfate may be reduced and bicarbonate formed, some minerals may be dissolved and others precipitated in water as it percolates through some soils.

\section{Weather Conditions}

Precipitation.--of course, has a fundamental effect on the quality of water in that it is a principal factor in the discharge rate of an uncontrolled stream. Sunny weather causes increased evaporation, especially if accompanied by wind and high water temperature, and would increase the water concentration of dissolved solids in the water. Over a period evaporation from a water surface may be balanced by precipitation directiy on that surface. For example, in 1932, the total evaporation from the water surface of the Delaware River and Bay was computed to be 909,800 second-foot-days (Pa. Dept. of Health, 1935, Appendix A, Index no. 20) and the total precipitation 954, 300 second-foot-days, a net increase for the year of 44,500 second-foot-days. This is approximately 1 percent of the average annual discharge. The short term effects can be much larger, although still negligible as far as dilution or concentration of the river water is concerned. For example, the Delaware Bay and River from Trenton to the Capes has an estimated capacity of 500 billion cubic feet and a surface area of $\mathbf{7 7 7}$ square miles. It is readily calculated that one inch of rainfall over the entire surface for 24 hours would be only 0.004 percent of the volume of the water and therefore it would have a negligible effect on its concentration. This does not, of course, include the effect of runoff from the land areas.

Barometric pressure. --Barometric pressure affects the mean river level. If, for example, the barometric pressure over the river is lower than that over the ocean at the river mouth, the difference in pressure will cause the mean river level to rise and the tides to be higher than otherwise.

Winds. --On-shore winds tend to drive water into an estuary and thus to cause the tides to be higher than in the absence of winds or when the wind is in such a direction as to blow water out of the bay. This is illustrated by the following quotation (Connecticut WPA, 1938, p. 44): 


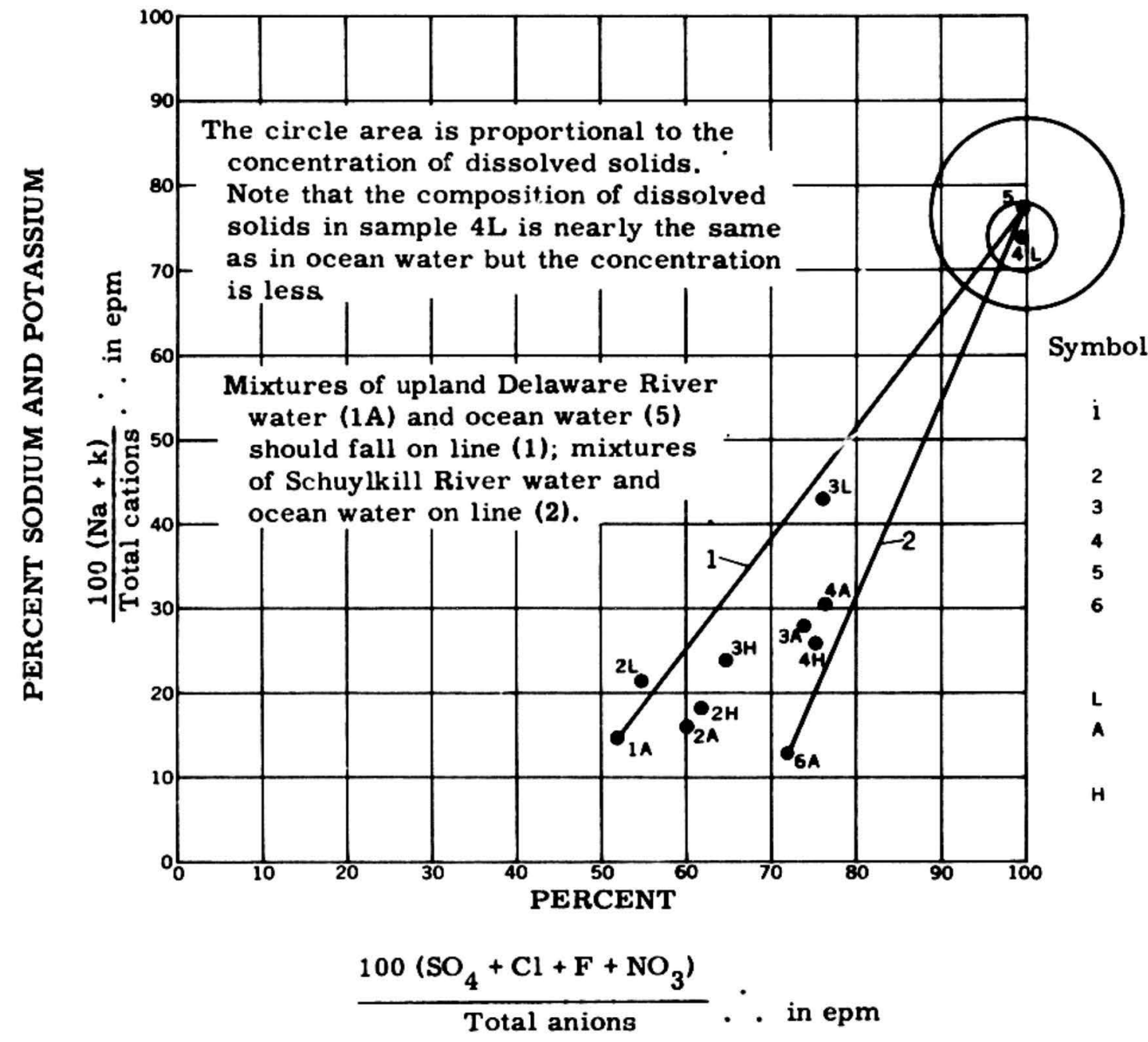

\section{Sampling location}

Delaware River at Morrisville, Pa., 1944-46 average

Delaware River at $\mathbf{B r i s t o l}, \mathbf{P a}$.

Delaware River at Vine Street, Phi.a.

Delaware River at Marcus Hook, Pa.

Ocean water (Sverdrup, Thompson)

Schuylkill River at Belmont Filters, Philadelphia

Low flow, 2500-2750 cfs at Trenton, N. J. Average flow, 10,000-13, $000 \mathrm{cfs}$ at

Trenton, N. J.

High flow, 32, 000-42, $000 \mathrm{cfs}$ at

Trenton, N. J.

Circle Diameter

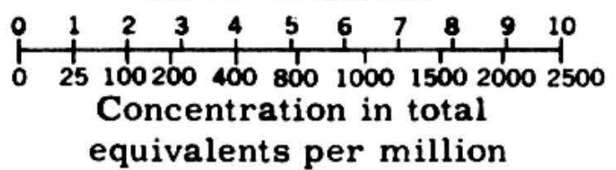

equivalents per million

Figure 14. -- Langelier - Ludwig plot showing mixture of river water and ocean water. 
"When there is a steady easterly wind for two or three days, there is a tendency for the Long Island Sound water to pile up on the Connecticut shore. This means exceptionally high tides and the effects are noted . . . eleven miles from the mouth of the Connecticut river. During such periods, the low tides will commonly be as high as the normal low high tide."

"Strong northeast winds tend to create a reverse condition . . . southwest winds . . . have no appreciable effect on the height of tide."

Wind direction and velocity may also have a marked effect on the lateral distribution of salinity across an estuary (Tully, 1949, p. 24).

\section{Effect of Pollution}

Pollution entering a tidal river is not immediately swept downstream to the ocean. If it enters the stream on the flood tide, it will be carried upstream until the tide changes. Even when introduced into the river on the ebb tide it will be swept upstream again on the following flood; under some conditions it may be carried upstream past the point of introduction. Phelps, in Stream Sanitation (John Wiley and Sons, 1944, p. 23) says that in the Hudson River above New York City the normal range of upstream movement is 10 miles. Normally, however, each successive tidal cycle dilutes the pollution more and carries it downstream further.

In order to treat this situation quantitatively Ketchum (1951a) and others have developed an interesting theory of tidal flushing. Ketchum divides the estuary into consecutive volume segments, each of length equal to the average excursion of a water particle on the flood tide. This is the maximum length of segment in which could be expected complete mixing of the water added to the segment during the tidal cycle. This object is attained if each segment has a high-water volume equal to the low-water volume of the adjacent seaward segment. Then the fraction of water removed from any segment of the river on the ebb tide is the quotient of the local intertidal volume divided by the high-water volume of the segment. This fraction is called the exchange ratio, and also represents the fraction of any dissolved substance, which is removed on the ebb tide. The theory permits the calculation of the concentration of chloride, for example, for any location in the estuary from such basic data as the discharge rate of the river, composition of the water at the upstream and downstream ends of the estuary, and river capacities or cubatures at low tide and high tide. Since the theory is based upon an idealized situation, perhaps one should not expect too much from it in a quantitative sense. However, Ketchum has successfully applied the theory to describing the distribution of salinity in the Raritan River and Bay, N. J., the Alberni Inlet, Vancouver, B. C., and the Great Pond, Falmouth, Mass., and more recently (Ketchum, 1952) with surprising success to the distribution of coliform bacteria in the Raritan River.

Arons and Stommel (1951) have translated Ketchum's theory into the language of the physics of continua and have calculated a series of curves showing a semi-empirical relationship between salinity and longitudinal location on the river. Stommel (1953) has recently proposed a new method of computing estuarine pollution which is of more general applicability than the earlier methods. The approach is semi-empirical.

Nusbaum and Miller (1952) calculated from Ketchum's theory the amount of oxygen brought into San Diego Bay from the ocean water by tidal action. They also calculated the rate of oxygenation from the atmosphere and from chiorophyll-bearing phytoplankton but did not get a complete correspondence between the calculated oxygen demand of the pollution and the actual oxygen consumed.

The tidal flushing theories of Ketchum and of Arons and Stommel are critically discussed by Pritchard (1952). In calculations based on Ketchum's theory the salinity at the seaward end of the estuary is a critical factor. This quantity is difficult to evaluate for an estuary which is tributary to a larger estuarine system. The consecutive volume segments into which 
Ketchum divides the river are satisfactorily defined for estuaries in which the tidal wave is essentially a standing wave, but not for large estuaries - where the tidal wave has progressive wave features. In many coastal estuaries, also, vertical mixing is incomplete, yet river water is found both in the upper, less saline layer, and in the lower, more saline water. The lower layer will then carry river water up the estuary due to its net up-stream motion. Arons and Stommel deal with a much simplified estuary and, like Ketchum, assume the estuary to be vertically homogeneous. Pritchard develops a differential equation for the instantaneous local rate of change of salt concentration which includes three advection terms and three random flux terms. For the James River estuary certain of these terms are shown to be negligible and others can be evaluated from an extensive series of observations of velocity and of salinity at several cross-sections of the estuary. The differential equation is evaluated for three sections of the James River estuary, each observed at neap tide, spring tide and between neap and spring tides.

Pollution may be introduced into a river continuously, as is the effluent from many sewage treatment plants or in intermittent slugs, as when a tank of electroplating solution is dumped, or when accidental spillage occurs. Its effect may be quite different in the two cases. It has also been observed that pollution may become entrapped behind piers or other obstructions and remain relatively undisturbed for a number of tidal cycles, for in such locations tidal currents are at a minimum. Flood discharge may remove entrapped pollution, due to eddy currents. The Corps of Engineers, U. S. Army (1953) are presently conducting tests on the flushing characteristics of estuaries, using flumes and hydraulic models of estuaries.

\section{FLUVIAL SEDIMENT IN TIDAL RIVERS}

River:s acquire sediment through erosion processes, and to a lesser extent from pollution. As a river flows from upland regions, perhaps mountainous, to the sea its gradient and its competence to transport coarse sediment in general decrease. The decrease in competence permits the aeposition of some part of the sediment load, the coarser particles settling first. At times of flood, due to higher velocity and greater turbulence, sediment is carried farther downstream before it is deposited. In general, forces of erosion increase with velocity and turbulence and sedimentation occurs in areas of low velocity and low turbulence. Material deposited in the river bed at any one time may later be scoured away and deposited farther downstream. As sediment moves downstream some sorting takes place, the coarser sediment being found in the upper reaches of the river and finer sediment in the seaward portions of the river.

In a tidal river movement of water varies and may reveise its direction on each change of tide, so that, in estuaries where two high tides occur each day the movement of water may cease four times in a lunar day, and for nearly half the time may be in the upstream direction. The sand and silt fractions of the inflowing sediment load will be progressively deposited as the turbulence of the inflowing water diminishes. The clay or fine fraction of the inflowing sediment load will generally tend to remain in suspension until mixing of fresh and salt water occurs. Then the clay-size particles flocculate into larger particles with greatly increased settling rates. As the velocity varies in magnitude and direction during the tidal cycle the less resistant deposits are scoured from the stream bed and carried upstream or downstream depending upon whether the tide is flooding or ebbing. The ultimate place of deposition of the sediment depends upon a number of factors, many of them local. Flood flows carry the sediment closer to the mouth of the river. Where the river cross-section is large, velocity will be less and sedimentation greater than in adjacent parts of the river having a smaller cross-section Thus dredging a deeper channel may favor sedimentation and shoaling. Where the ebb current occurs in one channel and the flood current in another, shoaling may take place in the relatively quieter waters between the the two channels.

Sediment loads in rivers upstream from the tidal zone are generally calculated from the discharge and the concentration of suspended sediment. Similar quantitative calculations and interpretations for tidal rivers are more complex. In the first place, the location of zones of deposition will depend on the velocity of flow, which varies periodically with the tide, being 
positive on the ebb tide, negative on the flood tide and zerc at each slack water. Moreover, the periodic variation in velocity usually differs for two successive tidal cycles. The cross-section of a tidal river is generally much wider than that of an upland stream, and the cross-section is usually nonhomogeneous with respect to velocity. The problem of sediment sampling of a tidal river is consequently a very complex one, and will not be discussed in this report. It is in part discussed in a "Study of Methods Used in Measurement and Analysis of Sediment Loads in Streams," a series of reports sponsored by the Federal Interagency River Basin Committee, of which the U. S. Geological Survey is one of the participating agencies.

\section{SAMPLING EQUIPMENT AND METHODS}

\section{Boat, Bridge or Wharf}

The waters of tidal streams may oe sampled from a boat, bridge, or wharf. Of these, sampling from a wharf is the least likely to be satisfactory, because of the possibility of eddy currents close to the wharf-end. Sometimes localized pollution pocketed behind a wharf or pier washes out but slowly. Sampling from a bridge can be closely duplicated as to location on subsequent sampling dates. The bridge, however, may be too high for convenient sampling, or be located at a point where the river is subject to local variation because of tributary flow, pollution or river currents. Sampling from a boat has the advantage of flexibility in choice of sampling locations and of mobility in re aching a number of sampling points. The sampling locations should be specified with reference to buoys, bridges, buildings, chimneys, wharves or other distinctive landmarks. At night, lighted buoys are helpful. They may be improvised from an oil drum to which is tied a small raft with a lantern. Permission is required to place buoys in navigable streams.

Various types of boats have been used for water sampling tidal rivers. In the Connecticut River study (Connecticut WPA, 1938, p. 18)

"It was found that a so-called "harpoon" boat with flares in front and equipped with an eight horse-power outboard motor was the most suitable type for most of the work on the river. However, a 22 -foot boat with an inboard motor is best for rough conditions."

In the Delaware River salinity survey (Pa. Dept. of Health, 1935) two boats were used. One was a 36-foot cabin boat having an 11-foot beam and 4-foot draft, and equipped with a four-cylinder gasoline engine. The other was a steel boat 16 feet long and 4 feet wide, with outboard motor. In Tully's study of the Alberni Inlet (Tully, 1949) a semi-diesel motor cruiser of 35 tons displacement was used. A large boat with inboard motor is more suitable for rough weather, but a smaller boat is portable, by means of a trailer.

When sampling from bridges it is desirable to have red lanterns and GO SLOW signs. Boats should be equipped with fire extinguishers, searchlights, and life preservers. The hazards of navigation must be recognized and circumvented - if necessary, by leaving the boat at anchor. For example, river flow or strong winds may give rise to eddy currents or whirlpools. In rough weather it may be difficult to place the boat on station. Advice on navigation is given in the Connecticut River study (loc. cit. p. 32).

"Meeting waves squarely on the stern will cause the boat to stay and plane on one wave, similar to surf riding. This is dangerous, for, in trying to leave this wave, the pilot may lose control ot the boat unless the motor has speed and power enough to pull away."

In fog it may be necessary to stop the $r$ tor at intervals in order to listen for large ships. If navigating in ice it is well to remember thit changes in wind, current or tide may shift the position of ice floes in such a way as to cut the boat off from shore. 
The simplest way to collect a water sample is to lower an unstoppered bottle on the end of a rope quickly to the required depth. The bottle is clamped in a metal holder to weight it and hold it uprigitt. Jiggling the rope encourages the air to leave the bottle. When filled, the bottle is hauled up and stoppered. Some water will enter the bottle before it reaches the required depth. To avoid this the bottle holder is provided with lever arms for removing the stopper, and the bottle (stoppered) is lowered to the required depth. A "go-devil" or "messenger" is then slid down the supporting cable; the messenger actuates the lever arms and removes the stopper. Alternatively, a pole is provided with supports and clips for holding bottles at the desired depths. By means of a stout cord running through eyelets on the pole, the stoppers can be removed from all the bottles simultaneously by a sharp, quick pull on the cord.

Samples may be taken at any specified depth with a sample such as the Foerst sampler (Foerst Mechanical Specialties Co., Chicago 47, Ill.). This consists of a metal tube which may be closed at both ends by rubber stoppers. The stoppers are supported on a brass rod and held away from the ends of the tube while it is lowered, in a vertical position, to the desired depth. A messenger is then sent down the cable, closing both stoppers against the ends of the tube, entrapping the water sample while it is hauled to the surface. An outlet is provided in the bottom stopper for releasing the water to the sample bottle with a minimum of aeration. The sampler is made in three sizes: $1200 \mathrm{cc}, 2000 \mathrm{cc}, 3000 \mathrm{cc}$ capacity.

Thompson and Robinson (1932 b) describe several types of reversing water-sampling bottles used in oceanographic sampling. For example, Nansen bottles are metal bottles with valves at each end. They are lowered into the water with both valves open until they reach the required depth. A "messenger" causes the bottle to reverse this action also closing the valves and trapping the enclosed water sample. A number of these bottles can be lowered on the same wire to several depths. As the top bottle reverses, it simultaneously releases a messenger which reverses the next bottle, etc. This type of bottle is lowered on a cable which is unwound from a reel, so constructed that a specified length of cable is paid out on each turn of the reel. An improved type of sampling bottle is described by Fjarlie (1953).

In some situations an integrated sample, rather than a sample at a specified depth, may be required. When sampling from a bridge this may be accomplished satisfactorily in the following manner: swing the bottle in an arc twice the depth of the river, allow the bottle to sink and drift with the current, so that it fills with water by the time it reaches a point immediately below the collector. This will be sufficient to fill a 12 -ounce $(370 \mathrm{cc})$ citrate bottle. For a larger bottle more than one swing will be required.

In the 1929 study of the Sacramento-San Joaquin Delta and Upper San Francisco Bay (California Department of Public Works, 1931, p. 250) samples at specified depths were taken with a pump and hose:

"A bucket-spray pump was converted by removing the screen and foot piece and welding in its place a one-half inch tee with the 'run' horizontal. To one end of the tee was attached a street ell closed with a pipe plug and at the other end, a hose adapter was inserted. This completed the pump which had a weight of about $7 \frac{1}{2}$ pounds. A high-grade one-half inch garden hose was chosen for a combined sounding line and conduit to convey the water from the desired depth. This was attached to the pump by a female coupling and the free end was closed with a one-half inch vertical check valve. . . . the hose was graduated by using hose clamps as markers with one clamp at the ten-foot mark, two clamps at the twenty-foot mark, and similarly, additional clamps for greater depths. Heavy cord was wrapped at the intervening five-foot marks. ... a standard fifteen-pound current meter weight . . . was fastened so that the bottom was just two feet from the end of the hose, thereby avoiding the possibility of the end of the hose touching bottom and pumping up mud. The capacity of fifty feet of one-half inch hose is about one-half gallon. Therefore, to insure complete flushing of the apparatus, a gallon of water was pumped before 
taking each sample. When depths necessitated using two lengths of hose, double the amount was pumped. This apparatus was used very successfully in water with a depth of eighty-six feet and a velocity of about six feet per second. However, with such high velocities, it was necessary to use a graduated stay line, manipulated by an extra man, to maintain the hose in a vertical position."

It seems probable, however, that this procedure might affect the dissolved oxygen content of the sample. Other chemical-physical relations in the water may also be affected. Unless it can be demonstrated that this is not the case, another sampling method should be used.

\section{Temperature Measurements}

Temperature measurements are most simply obtained with a pocket-type thermometer, protected by an armored case with cut-away front so that the thermometer may be read while in the case. A range of $+20^{\circ}$ to $+110^{\circ} \mathrm{F}$ is suitable. It may be read to the nearest whole degree and should be checked or calibrated in the laboratory before placing in use. The thermometer is fastened securely in the sampling bottle, the bottle (in its metal holder) submerged for a minute or longer, and the temperature read immediately upon withdrawal while the thermometer is still immersed in the water. (See W.R. D. Memorandum, October 1952, "Temerature Surface Waters").

Temperatures may also be obtained with mercury-in-glass reversing thermometers. These are so-constructed that when the thermometer is turned over the temperature reading at that time remains on the calibrated stem, irrespective of subsequent temperature changes. The thermometer may be attached to the frame holding the Nansen bottle or in a separate case which can be reversed by sliding a messenger down the supposting cable.

In some studies of Lake Mead (Anderson and Pritchard, 1951) a bathythermograph was used:

"A bathythermograph provides a continuous record of temperature versus depth. A stylus, attached to a Bowdon tube, records the temperature on a smoked glass slide. The slide is hela in a frame attached to a pressure bellows, and hence the frame and slide move relative to the arc of the stylus as the depth changes. The bathythermograph gives relative temperatures to an accuracy of $0.1^{\circ} \mathrm{F}$. Surface temperatures from surface thermometers and subsurface temperatures from reversing thermometers are used io calibrate the bathythermograph record."

The bathythermograph must also be calibrated for depth, and the calibration changes with the salinity (density) of the water. The density difference between fresh water and sea water requires a correction of 2.5 feet per 100 feet of depth. Complications will arise where the rate of change of density is non-uniform, as when there is a salt-water wedge.

A resistance thermometer with long insulated leads could be used for temperature measurements at various depths. The Whitney thermometer (L. V. Whitney and Son, 1218 West Linwood Drive, Springfield, Missouri) is a battery-operated portable instrument. The temperature is read from a microammeter directly to $0.1^{\circ} \mathrm{F}$, by visual estimation to $0.02^{\circ} \mathrm{C}$. Thermoclines are measured by lowering the thermometer element slowly until a change in temperature is evident from a shift in the microammeter needle. The element is then held in position until it is in temperature equilibrium and the temperature is then read on the microammeter scale.

\section{Electrical Conductivity}

Since electrical conductivity (reported by Geological Survey as specific conductance in micromhos at $25^{\circ} \mathrm{C}$ ) increases with the salinity, field measurements of electrical conductance are useful for quick exploration, e. g. , to determine the existence of salinity variations in depth, transversely, or longitudinally. At a place on the stream where electrical conductivity is found not to vary, a single water sample may be representative, whereas if a sharp change in conductivity is found at a certain depth a minimum of two samples will be required - one above and one 
below the depth at which the sharp change is observed. Conductivity measurements can be made rapidly, even from a moving boat, and the results are immediately available so that further water samples may be taken in the light of information obtained from the conductivity measurement.

Electrical conductivity is a function of the salt concentration of water, and also of its temperature, the conductivity increasing about 2 percent per degree Centigrade rise in temperature. Therefore, temperature must be measured simultaneously with conductivity. Both the conductivity cell and the temperature-sensing element may be lowered on a wire rope to which the insulated cables are also attached. The conductance electrodes may be affected by oil, colloidal suspended matter, sewage, or industrial wastes so that the cell constant must be checked daily. When not in use the electrodes are kept in distilled water. In the Delaware River Salinity Survey (Pa. Department of Health, 1935) simultaneous temperature and resistance measurements were automatically recorded on a chart, operated by clockwork. The conductivity recorder had a triple range: 5 to $150 \mathrm{ohms}, 125$ to $600 \mathrm{ohms}$, and 500-600 ohms. Additional description of equipment is given in the above report.

\section{Field Notes}

The field notes will contain a number of observations descriptive of the samples and of the conditions under which they were obtained. The particular items noted for each sample will depend upon the reasons for taking the sample, but the following list may be suggestive:

Date

Time of day

Samp!ing location

Longitudinal

Trinsverse

Depth

Water level measurements

Discharge rate

Tide

Elevation

Current direction and strength

Water temperature

Electrical conductivity

Type of sampler

Weather conditions

Rain, snow, sunshine

Winds; direction and strength

Ice

River traffic, dredging, etc.

Observer

\section{SUMMARY}

Some of the natural phenomena have been described that affect the mixing of river water and ocean water in tidal rivers. The operation of these phenomena result in variations in the salinity of different parts of the river. Most evident and most important are the longitudinal variations, i. e., the profile, or variations up and down stream, for from these variations one may infer the extent of ocean-water intrusion. The intrusion of ocean water into a tidal river is influenced by any factor which changes the hydrostatic head of the ocean relative to that of the river. For example, the barometric pressure at the mouth of the river may differ from that up-river; the discharge rate may influence the river stage or even influence sea-level at the river mouth; winds often change sea-level at the river mouth.

In tidal rivers major changes in salinity are usually due to changes in discharge rate, but 
frequently lag behind the increase or decrease in discharge rate and depend upon the duration as well as the magnitude of the discharge. Thus, a persistent increase or decrease in discharge rate will usually initiate a trend toward decrease or increase in salinity in a tidal river. Superimposed on such trends are minor daily fluctuations in salinity due to changes in sea level (mean tide level). These changes in salinity are small in magnitude but occur on the same day as the change in mean tide level. In addition there is a periodic increase and decrease in salinity accompanying the rise and fall of the tide. The amplitude of this variation in salinity de pends upon the range of the tide, the variation in salinity being greater as the range of tide increases.

Longitudinal variations in salinity are always found in a tidal river; transverse variations (from bank to bank) and vertical variations (from surface to bottom) often occur. It is necessary to know whether cross-section variations exist if one is to get a representative sample of river vater at any location. Cross-section variations are found where fresh water discharges over salt water on the bottom (salt-water wedge), and may also arise from Coriolis forces (from earth's rotation) or be due to channel configuration, e. g. , the ebb current may follow one bank and the flood current the otiner. The waters of a tributary, or source of pollution, may follow the bank of the river - not mixing completely until some distance downstream (or upstream) from the confluence. The effect of the seepage of ground water into the river may be important, but in general has not been evaluated. Cross-section variations are expected to be less - but not always eliminated - where river traffic is heavy, as the passage of shipping has a mixing action.

Not only is each river unique in the way discharge rate, tidal conditions, and weather influence the salinity at a given location, but in addition its behavior may change from year to year due to the acts of man. Dredging of channels, the filling of swamp areas and the building of dikes and breakwaters may alter the tidal regime. Impounding or diversion of water may affect the upland flow so as to give longer or shorter low-flow periods with a consequent effect on the extent of salinity intrusion.

Any study of the chemical quality of water in a tidal river will, therefore, have several objects. It will attempt to establish, for the record, and for the period of sampling, the character of the water in various parts of the river, including the variations in water quality. The study should also attempt to show the causes of these variations. Where sufficient data have been obtained predictions relative to water quality may be made, for example, a prediction of the discharge rate required to assure that the salinity of the water at a specified location will be less than $100 \mathrm{ppm}$ chloride. Few studies of tidal rivers so far made have included a sufficiently lengthy period of time to permit accurate predictions.

A number of investigations of the chemical quality of water in tidal rivers have been cited. The kind of data needed and the nature of the sampling program to record these variations in water quality have been discussed for particular cases. In a tidal river survey the deposition of sediment is of interest; in this report - concerned only with chemical quality - the sediment deposition problem has been set forth, but neither the question of sampling nor interpretation of sediment data have been dealt with. Because of the nature of each tidal river, no specific program of investigation, applicable to all rivers, can be set forth. Nevertheless, for one planning for a specific tidal river, a study of water quality variations, of pollution, or of salt-water intrusion, this report is intended to render aid in understanding the basic forces involved, to give some guidance in planning the study, and to offer some suggestions for interpreting and reporting the results. 


\section{ANNOTATED BIBLIOGRAPHY}

Anderson, E. R. and Pritchard, D. W., 1951, Physical limnology of Lake Mead: Lake Mead Sedimentation Survey, U. S. Navy Electronics Laboratory, San Diego, Calif. , Report 258. BUShips problem NEL2J1.

Arons, A. B. and Stommel, Henry, 1951, A mixed-length theory of tiulal flushing: Am. Geophysical Union Trans., v. 32, no. 3, p. 419-421.

Ketchum's (1951 a, b) fundamental idea - that the element of mixing volume is bounded iy the length of the tidal excursion is translated into the language of the physics of continua. A family of curves are obtained in which salinity (expressed as a fraction of ocean salinity) is plotted against distance along the channel (expressed as a fraction of the total length). The position of each curve depends upon a quantity called the "flushing number" which is a function of the river discharge per tidal cycle, the river depth, and the average tidal displacement. The flushing number also depends upon a proportionality factor which could not be calculated from theory. The flushing number serves to characterize the estuary and the family of curves to express the mean salinity distributions.

California Department of Public Works, 1931, Variation and control of salinity in SacramentoSan Joaquin Delta and Upper San Francisco Bay: Calif. Dept. of Public Works, Div. of Water Resources, Bull. no. 27, 440 p. , 39 tables, 82 pls.

Diversions for irrigation reaching their peak when stream flow is low have resulted in increasing intrusion of salinity. The salinity increases only slightly with depth (maximum rate of increase 0.3 percent per foot of depth), the increase is greatest for salinities of about 10,000 to $13,000 \mathrm{ppm} \mathrm{Cl}$ and least as the salinity approaches that of ocean water or fresh water. There is no evidence of salt water creeping along the bottom or sides. The hourly variations in salinity during two complete tidal cycles is plotte $d$ for 14 stations and from these data are derived plots (1) of the rate of change of salinity per foot of tidal range against the mean salinity for the tidal cycle, and (2) the maximum salinity for a tidal cycle against the mean salinity for a tidal cycle. The maximum salinity occurs at high water slack and may be $200 \%$ above the mean; the minimum salinity, at low water slack, may be $80 \%$ below the mean. Relationships are developed between (1) the total annual stream flow and the minimum daily salinity, (2) the total stream flow from June 15 to Sept. 1 and the maximum salinity, (3) the discharge rate and the rate of advance or retreat of salinity, (4) the maximum salinity and the stream flow at the time of maximum salinity. However, it should not be assumed that the minimum stream flow during the season is directly related to the maximum salinity during the season. "If salinity in any degree is once present at any point in the tidal basin, these data indicate that a larger amount of stream flow is re quired to effect a decrease in salinity than would be required to prevent salinity of the same degree from increasing at the same point."

California Water Pollution Control Board, 1952, Water quality criteria: State Water Pollution Control Board pub. no. 3, 512 p., p. 43-46, "Dilution in tidal estuaries."

A brief summary of the tidal prism concept of dilution in tidal waters as developed by Ketchum. The "problem of dilution is exceedingly complex and not capable of precise theoretical evaluation."

Clarke, F. W., 1924, The data of geochemistry: U. S. Geol. Survey Bull. 770, 5th ed. , GPQ, Washington, D. C.

p. $119 \mathrm{~F}$. Average composition of river and lake waters. p. $127 \mathrm{~A}$. "Mean of 77 analyses of ocean water from many localities, collected by the Challenger expedition, W. Dittmar, analyst, Challenger Rept., Physics and Chemistry, v. 1, 1884, p. 203. Salinity 3.301 to 3. 737 percent."

Connecticut, Works Progress Administration for, 1938, The salinity of the Connecticut River, October 1, 1934, to September 30, 1937: Bull. S-1, Parts I, II, and III, 75 p. , 166 p., and 324 p. (mimeo.)

A study of sea-water intrusion into the tidal portion of the Connecticut River, based on 
159,000 samples of river water, obtained at 76 stations at 21 sections on the lower Connecticut River. Maximum salinity occurs at high slack water. The extent of salt-water intrusion is affected by river discharge, the tides and currents, winds, bridge abutments, piers, passage of boats, and river contour as affected by floods and dredging. Parts II and III are devoted entirely to tabulation of the results of chloride tests at Saybrook Highway Bridge. In one tabulation analyses are sorted by the stage of tide when the samples were taken, in another tabulation simultaneous samples were taken for each 2 feet of depth at several stations. See Howard, 1940.

Corps of Engineers, U. S. Army, 1952 a, The Delaware River model: prepared for the Committee on Tidal Hydraulics, Waterways Experiment Station, Vicksburg, Mississippi, 10 p. , 8 photos., 11 pls.

A description of the Delaware River model and the kinds of tests for which it is useful. Plates 4, 5, and 6 show maximum and minimum salinity profiles obtained with the model and those observed for the prototype at the surface, mid-depth, and bottom of the river.

Corps of Engineers, U. S. Army, 1952 b Delaware River model study, Report no. 3, Effects of proposed channel enlargement between Philadelphia and Trenton: Tech. memo. no. 2-337, prepared for the District Engineer, Philadelphia District by Waterways Experiment Station, Vicksburg, Mississippi, 14 p. , 3 photos., 35 pls.

It is stated that the enlarged channel would not increase salinity in the estuary for normal or very low fresh-water discharges. At very low discharge rates salinity intrusion increased through 220 tidal cycles in the model. Salinity profiles are given in plates 10, 11, (bottom, surface), 31, 32, 33 (bottom salinity at neap, mean and spring tides), 34,35 .

Corps of Engineers, U. S. Army, 1953, Tidal flushing of estuaries, Report no. 1, Proposed program of investigations for fiscal years 1953 and 1954, Tech. memo. no. 2-374, prepared for Office, Chief of Engineers by Waterways Experiment Station, Vicksburg, Mississippi. 8 p., appendix A (report of conferences with consultants on tidal flushing of estuaries) $5 \mathrm{p}$.

The objectives of the investigation are to study the basic fundamentals of tidal flushing to make possible the "accurate computation of the dispersion, dilution, or accumulation of contaminating agents" and "of the effects of proposed changes in the physical characteristics of estuaries on their flushing characteristics." In addition it is hoped to obtain empirical data on factors influencing the flushing characteristics of certain estuaries from tests on existing hydraulic models. A series of tests in two flumes of rectangular cross-section are planned as well as 25 flushing tests for the Delaware River model and 9 for the Charleston Harbor model. Among the factors to be investigated are: the location of the contamination, the size of the contaminated area, tidal amplitude, fresh-water discharge, concentration of contamination, and tidal plane. The consultants stated their opinion "that existing (February 1953) theories are not sufficiently realistic to permit analytical determination of the flushing characteristics . . . that the size and inter relationship of the turbulent eddy system which controls salinity distribution in an estuary is not necessarily the same as that which controls movement and dispersion of a contaminant in the estuary."

Corps of Engineers, U. S. Army, 1954, Committee on Tidal Hydraulics, Report no. 2, Bibliography on Tidal Hydraulics, 208 p., the Recorder, care of Waterways Experiment Station, Corps of Engineers, P. O. Box 631, Vicksburg, Mississippi.

An annotated bibliography of 836 references (in English) available on loan from the Research Center Library, Waterways Experiment Station, or at other offices of the Corps of Engineers. The bibliography is divided into eight sections: theoretical considerations (including mechanism and types of tides, estuarine circulation, metereological effects), sedimentation in tidal waterways, salinity effects (including salt-water intrusion, salinity currents, contamination by salt water as distinguished by contamination from other sources), contamination from industrial wastes and sewage, regulation and improvement, laboratory experiments such as model studies, surveys and instruments, ard basic physical data (including tide tables, tidal current charts, physical features of estuaries). 
Current Tables, see U. S. Coast and Geodetic Survey.

Durum, W. H. , 1953, Relationship of the mineral constituents in solution to stream flow, Saline River near Russell, Kans.: Am. Geophysical Union Trans., v. 34, no. 3, p. 435-442.

Fjarlie, R. L. I. , 1953, A seawater sampling bottle. J. Marine Research v. 12, p. 21-30. A new type of sampling bottle consisting of a tube with hinged lids and a frame for holding reversing theromometers is described. It is claimed to be an improvement over the Nansen, Knudsen, and Ekman bottles in that it has good flushing characteristics and a positive seal when closed. Four photographs and two drawings show the construction of the bottle. Data are presented to show that the water in the new bottle was representative of the surroundings immediately, whereas the other bottles required from 30 seconds to 5 minutes before they were flushed with the water to be sampled.

Howard, C. S., 1940, Salt-water intrusion in the Connecticut River: Am. Geophysical Union Trans., v. 21 , p. $455-457$.

A summary of the results tabulated in Connecticut W. P. A., 1938, concerning samples collected from Octobır 1, 1934, to June 30, 1939. Salinity is greater at the bottom of the river, and penetrates further up the river the lower the discharge rate. A figure shows the variation in salinity at the bottom, mid-depth and surface over a complete tidal cycle on 8 successive days which include a six-fold change in discharge rate. Shortly after lowwater slack a rapid increase in concentration occurs, and after high-water slack an equally rapid decrease in concentration occurs. At low-water slack the chloride concentration is at a minimum and nearly the same at all depths. The salt concentration rises to a maximum at high-water slack but much less change occurs at the surface than at mid-depth or on the bottom. Mixing is erratic at mid-tide and even at similar discharge rates is not reproducible.

Jones, E. L., 1926, Tide and current investigations of the Coast and Geodetic Survey: U. S. Coast and Geodetic Survey.

Exact agreement is not to be expected between predicted and actual tides, especially in the upper reaches of rivers subject to freshet conditions or in shallow bays with small tidal range. Sixty to $\mathbf{7 0}$ percent of the predicted tides are within $\mathbf{5}$ minutes of the observed tide, 90-95 percent within 15 minutes of the observed tide. Since the tide changes slowly near the times of high water or low water, 15 minutes is of little practical importance.

Jones, P. H. , Hendricks, E. L., and Irelan, Burdge, Water resources of southwestern Louisiana: Manuscript copy, for administrative use only, U.S.G.S. in cooperation with Louisiana Geol. Survey (in files of U. S. Geol. Survey, Washington, D. C.).

Data from water resources inventory 1938-51, and an intensive investigation of ground, surface, and quality-of-water data in irrigation seasons of 1949, 1950, and 1951. During periods of salt water encroachment, salt water in the Vermillion River basin moves as a front while salt water in the Calcasieu River basin moves as a wedge. Factors influencing the salt water-fresh water contact are: discharge volume, depth and size of channel, sinuosity of channel, wind velocity and direction, ship movements, diversions, and wastes. In shallow channels horizontal stratification disappears as a result of better turbulent mixing, the salinity front is then perpendicular to the stream bottom. Since the density flow of salt water in any channel is controlled by the salt-water head at the entrance, shallow depths are a natural barrier to the movement of salt water up the Calcasieu River. As a result of dredging a 6 -foot deep ship channel to 30 feet deep, salinity intrusion up the Calcasieu River is more extensive and a given river discharge is less effective in combatting saline intrusion.

Ketchum, B. H. , 1950, Hydrographic factors involved in the dispersion of pollutants introduced into ticial waters: Woods Hole Oceanographic Institutiol. Contribution no. 515, Jour. Boston Soc. of Civil Engineers, v. 37, no. 3, July 1950, p. 296-314.

With the aid of an instrument which simultaneously records salinity, temperature, and 
depth, the lateral and vertical distribution of salinity in New York Harbor was oitained for the months of February, April, July, and October 1948 and August 1s49. From these data, the daily river flow, and the total volume of water, is calculated the volume of river water within a given area, and the flushing time, i. e., the average time for the river flow for one day to move through the area. This is the basic information required for determing the concentration of pollution in various areas and the rapidity with which pollution is dispersed.

Ketchum, B. H. , 1951 a, The exchanges of fresh and salt waters in ticial estuaries: Journal of Marine Research, Sears Foundation, v. 10, no. 1, p. 18-38.

Ketchum, B. H. , 1951 b, The flushing of tidal estuaries: Sewage and Industrial Wastes, v. 23, no. 2 , p. 198-208.

The distribution of pollutants in an estuary is determined by exchanges of fresh and salt water during the tidal oscillations. Ketchum divides the estuary into consectu tive volume segments, each of length equal to the average excursion of a water particle on the flood tide. This is the maximum length of segment in which could be expected complete mixing of the water added to the segment during the tidal cycle. From a mathematical treatment of the exchanges of fresh and salt water between segments on the end and flood tides, assuming a constant rate of river flow and constant mean tidal range, are calculated the steady-state distribution of fresh and salt water, and of pollutants, in the estuary; the average time required for river water to flow from one part of the estuary to another, and the total volume of water escaping seaward (and not returning) through any cross section. The theory has been successfully applied to three tidal basins of varied volume and configurations.

Ketchum, B. H. , Ayres, J. C., and Vaccaro, R. F., 1952, Processes contributing to the decrease of coliform bacteria in a tidal estuary: Ecology, v. 33, p. 247-258.

Coliform bacteria disappear rapidly in tidal waters. In the Raritan River on June 26 and 27, 1949, the average coliform population above New Brunswick was 115,000 cells per $\mathrm{ml}$, at Perth Amboy, 30 cells per $\mathrm{ml}$ at high tide, 130 cells per $\mathrm{ml}$ at low tide. Quantitative calculations show that dilution, the bactericidal action of sea water, and predators account for 99 percent of the reduction. Sedimentation is a factor in removing bacteria, but was not evaluated here. Near New Brunswick dilution, bactericidal action, and predators are of nearly equal effectiveness. At the mouth of the river bactericidal action accounts for 35 times as much bacterial mortality as dilution, at high tide, or 26 times as much at low tide (the water has not been in the estuary as long at low tide as at high tide).

Data are presented on the distribution in a longitudinal section at high and low tides, of salinity, oxygen, bacteria plate count, coliform bacteria, and of zooplankton.

Keulegan, G. H. , 1949, Interfacial instability and mixing in stratified flows: Journal of Research of the National Bureau of Standards, v. 43, p. 487-500 (RP2040).

The intrusion of salt water in rivers is a form of stratified flow in which the conditions at the interface control the mixing of fresh and salt water. The hydraulics of mixing were studied experimentally in short flumes and mathematically.

Lamar, W. L. , 1940, Salinity of the Lower Savannah River in relation to stream-flow and tidal action: Am. Geophysical Union Trans., v. 21, p. 463-470.

Tidal cycle studies, each covering about 27 hours, were done at 8 stations. Maximum salinity occurs from shortly after to several hours after high tide, the interval being affected by stream-flow, tide, wind, location of the sampling station, the extent of salt-water intrusion, and the nature of the river-section. The maximum salinities of top, middle, and bottom samples do not necessarily occur simultaneously. The higher high tide produces a higher salinity than the lower high tide. The longitudinal extent of saline intrusion (based

426 salinity profiles) is mainly influenced by the river discharge rate, but also by the 1... f-tide level and by the semi-monthly variations in tidal range. The farther upstream the sampling station is, the less stream flow is required to prevent the advance of a given degree of salinity. 
Langelier, W. F. and Ludwig, H. F., 1942, Graphical methods for indicating the mineral character of natural waters: Am. Water Works Jour., v. 34, p. 335-352.

A rectangular diagram for plotting the characteristics of natural waters. See fig. 14, in this report.

Lee, C. C., 1946, Salinity: a bibliography of books, periodicals, and society puidications appearing from 1845 through June 28, 1945: Compiled by Claude C. Lee, 1315 First North Street, Vicksburg, Miss., 80 p. typewritten.

More than $\mathbf{3 3 0}$ individual references, a subject index, and a chronological inciex. In many cases a short summary of the contents of the reference is given. Copies of this publication are in the Library of Congress, Washington, D. C., and the library of the Engineers Club, New York, N. Y.

Lindner, C. P., 1953, Intrusion of sea water on tidal sections of fresh water streams: Proc. Am. Soc. of Civil Engineers, v. 79, Separate no. 358, 35 p.

The problems of salt-water intrusion in estuaries is discussed, witi particular attention to the formation and behavior of the salt-water wedge. The effect of tides on salinity intrusion, and the flocculation and deposition of clayey materials are also discussed. A series of high low tides followed by a high high tide will force salt water further upstream than a high high tide preceded and followed by a low low tide. Plots of density vs. salinity and temperature vs. salinity are included for the determination of salinity from density measurements. Other plots show examples of the variation of salinity with tidal stage at several depths.

Marmer, H. A., 1949, Sea level changes along the coast of the United States in recent years: Am. Geophysical Union Trans., v. 30, no. 2, p. 201-204.

At New York, N. Y., from 1893 to 1930 there was only 0.13 feet rise in sea level, but from 1930 to 1947 there was a rise of 0.36 feet, at the rate of approximately 0.02 feet per year. At Baltimore, Md., records are available from 1903 and the rate of $r$ ise is the same as at New York. This may be due to an absolute subsidence of the coast or an absolute rise in sea level or a combination of the two. For the Coast of the Gulf of Mexico a similar rise in sea level took place. Sea level has also risen on the Pacific Coast, but at a lower rate.

Mason, W. D. and Pietsch, W. H., 1940, Salinity movement and its causes in the Delaware River estuary: Am. Geophysical Union Trans., v. 21, p. 457-463.

The tidal portion of the Delaware River extends from Trenton to the sea, about 130 miles. The $\mathbf{2 5}$ miles from Philadelphia to Trenton is alway' fresh, the $\mathbf{5 5}$ miles from Philadelphia to Artificial Island is a marginal zone of salinity. Figure 1 shows the average days of brackish water per year in the marginal zone. Figures 2 and 3 give the isochlor pattern in the Delaware Bay for extreme flood and extreme drought. Runoff aoove the salinity zone has a displacement effect, runoff entering the salinity zone directly has a diluting effect. The rate of advance or retreat of isochlor 50 during the 1930-31 drought was observed at a number of locations for various flow rates and a plot developed to show the fresh-water discharge rate required to hold the isochlor stationary at various locations on the river. "Vertical and transverse distribution of salinity at mean tide in the marginal zone is comparatively uniform. As might be expected, salinity near the top is generally about 10 percent less than at the bottom. Transversely, concentrations increase aioout 15 percent toward the Jersey side unless diluted by local runoff. These conditions are of course altered by flood-waters throughout the year. It was found that satisfactory average results could be obtained by taking samples at mid-tide, mid-depth, and mid-channel." (Note: The lower concentrations on the Pennsylvania side might be due to the influence of the Schuylkill and Christina Rivers or to Coriolis forces. Sampling at mid-tide is generally inadvisable in that the currents then are fastest and most erratic, resulting in erratic and rapid changes in chloride concentrations.)

Murphy, J. J., 1954, Salinity studies on tidal estuaries of the Eastern Shore of Maryland: U. S. Geol. Survey. (Open File Report - typewritten) 
Salinity samples were collected at the surface, mid-depth, and bottom on three or more days from July to October 1952 at several locations on the Pocomoke, Wicomico, Nanticoke, Choptank, and Chester Rivers and their tributaries. The sampling dates were so selected with respect to the lunar cycle that tidal variations were maximum, and the maximum upstream reach of salinity was determined by comparison with the analysis of non-tidal streams in the same region. When tidal variations in salinity occur, it is also found that the salinity is greater at the bottom. On the Pocomoke River, although tidal influence reaches as far as Schockley's Crossing, 25 miles above the mouth of the river, there was no significant increase in the chloride content of the water above Pocomoke City (5 miles from the mouth) regardless of the tidal stage. Apparently the marshland between Pocomoke City and the mouth of the river absorbs the penetration of bay water.

Nusbaum, Isadore and Miller, H. E., 1952, The oxygen resources of San Diego Bay: Sewage and Industrial Wastes, v. 24, p. 1512.

There are three sources of oxygen for reoxygenation of the Bay waters (1) from the atmosphere, (2) from chlorophyll-bearing phytoplankton, and (3) from oxygen saturated czean waters. Stream flow into the Bay is negligible, and the mean water temperature is approximately $20^{\circ} \mathrm{C}$. The rate of transfer of oxygen, in pounds per acre-day, was calculated from theory. The most important source of oxygen is from plankton and the pounds of oxygen available per day was estimated by incubating an extensive series of water samples from the Bay under light and dark conditions. The oxygen available from the ocean waters was calculated with the help of Ketchum's theory (1951 a). The actual oxygen demand is greater than that calculated for the wastes. It may be that high waste loadings result in decreased plankton activity, and therefore less available dissolved oxygen, or that surface active substances influence reaeration from the atmosphere.

O'Brien, Morrough, 1952, Salinity currents in estuaries: Am. Geophysical Union Trans. , v. 33 , no. 4 , p. 520-522.

Current measurements in the Columbia River estuary on June 20-22, 1932, and salinity surveys before, during, and after the freshet season were obtained by the Corps of Engineers. The reversal of current at high water occurs first at the surface, while the reversal at low water starts near the bottom. The paper presents a method of separating the effects of tidal, fresh-water, and salinity currents. "During periods of small freshwater flow, each tidal cycle includes phases during which the salinity currents are of the same magnitude as the tidal currents, and hence these currents are not negligible." particularly in a deep estuary or bay, salinity currents may play an important role as regards the silting and scouring of channels.

Pennsylvania Department of Health, 1935, Final report on the salinity survey of the Delaware River: Pennsylvania Dept.' of Health, Bur. Eng. Report to the Sanitary Water Board, 75 p. plus supplements and appendices (mimeo.).

A large number of top, mid-depth, and bottom samples were taken at various locations in the saline part of the river. At each location maximum salinity occurs at high-water slack, about 1 hour after high tide. The salinity changes most sharply midway between high and low tides, and samples taken then may be misleading. The upstream advance of salinity intrusion is favored by low stream discharge rates, particularly if of long duration. The further upstream salinity intrudes the more sensitive it is to small quantities of fresh water, while if the salinity front is well down the river even a large increase in stream flow will result in but slight further retreat of salinity. Retreat of a saline intrusion is favored by lower tides and by strong northwest winds (which cause abnormally low tides).

The report includes a number of interesting charts. Drawings C-136, C-137, and C-138 may be used to determine salinity of the Delaware River at low water slack from the salinity at high water slack, or the duration of any intermediate salinity. Drawings C-81 to C-90 may be used to find the chloride concentration at any tidal stage if the chloride concentration at high-water slack is known. Drawing C-101 and others show for the years 1907 to 1934 (1) the daily discharge rate of the river, and (2) the daily location of the 200 ppm isochlor. Drawings C-47, C-73, and C-56 show for the years 1931, 1932, and 1933 (1) the daily discharge rate of the river, (2) daily mean air temperatures, (3) tidal condi- 
tions, i. e. , daily range and heights, (4) the phase of the moon, and (5) the locations of the isochlors for $50,100,200,500,1,000,2,000,5,000$, and $8,000 \mathrm{ppm}$ of chloride. Drawing C-75 shows the discharge rate required to hold stationary from day to day the $200 \mathrm{ppm}$ isochlor at any location on the river.

Piper, A. M. , 1944, A graphical procedure in the geochemical interpretation of water analyses Am. Geophysical Union Trans., v. 25, pt. 6, p. 914-928.

A trilinear diagram for plotting the characteristics of natural waters. Discussion by R. A. Hill and W. F. Langelier.

Pritchard, D. W. , 1952, Estuarine hyrirography, in Advances in Geophysics, H. E. Landsberg ed. v. 1, p. 243-280. Academic J?ress, Inc., New York, N. Y.

Investigations of the circulation of water in North American estuaries are critically discussed and a theory of the dyiamics of estuarine circulation is presented, applicable to shallow estuaries in which the shallow depths and sloping sides affect mixing. The theory has been applied in a semi-empirical study of the salinity distribution in the James River estuary. In this estuary there is a lower layer of greater salinity than the upper layer. See p. 40.

Rhodes, R. F. , 1950, Effect of salinity on current velocities, in Corps of Engineers, U. S. Army, 1950, Evaluation of present state of knowledge of factors affecting tidal hydraulics and related phenomena: Corps of Engineers, U. S. Army, Report no. 1 of the Committee on Tidal Hydraulics, p. 41-100.

Salinity data pertaining to the Savannah River, Charleston Harbor, the Delaware River, and the lower portion of the Mississippi River are discussed, for example (1) surface middepth, and bottom salinities at various tidal ranges and fresh-water discharges (2) salinities, tidal heights, and tidal current velocities throughout a complete tidal cycle. Differences in salinity in the same body of water tend to produce currents flowing along the bottom from regions of high to low salinity. The rise of tide in the ocean causes a flood flow into a tributary river, and the ocean water enters the tidal river in the form of a wedge moving along the bottom. The factors affecting the shape and movement of this wedge are discussed.

Sale, J. W. and Skinner, W. W. , 1917, The vertical distribution of dissolved oxygen and the precipitation of salt water in certain tidal areas: J. Franklin Inst., v. 184, p. 837-848.

The dissolved oxygen near the bottom of the Potomac estuary and in portions of Chesapeake Bay is less than in the water at the surface, apparently due to the under-run of salt water and the subsequent depletion of oxygen by plant and animal respiration, by direct oxidation of dead organic matter, and by bacterial decomposition. Stratification in the Potomac estuary persists in spite of strong winds or heavy rainfall. Maximum turidity is observed where the tidal river first mixes with salt water. The chloride concentration, turbidity and dissolved oxygen were determined for about 275 surface and deep samples collected frum the Potomac River, Md., the Maurice.River, N. J., and the Chesapeake and Delaware Bays during 1912 and 1913.

Smith, E. V. and Thompson, T. G., 1927, Salinity of the Lake Washington Ship Canal: Washington (State) University Engineering Experiment Station, Bull. no. 41, 104 p.

Chloride concentrations in Lake Union, Lake Washington, and the Lake Washington Ship Canal. Discusses the design and operation of the canal to prevent salt-water intrusion through the canal. Shows salinity variation with depth for each month of the year. Salinity tends to remain relatively constant on the bottom, with seasonal flushing nearer the surface.

Stauber, L. A., 1943, Graphic representation of salinity in a tidal estuary: Jour. of Marine Research (Sears Foundation, Yale Univ.), v. 5, no. 2, p. 165-167.

The salinity of the water is important in controlling the movement, feeding, and spawning of oysters. A graphic method is used for presenting salinity data, showing the variations in salinity at several locations on Delaware Bay. This consists of a map with station locations marked; below the map is a plot of salinity (ordinate in parts per mille). A circle 
represents the salinity of the sample, a vertical line drawn tangentially to the circle indicates the range of salinity (from hourly samples over a complete tidal cycle). If the salinity sample was taken at the surface, the vertical line is drawn to the left of the circle; for a bottom sample the line is at the right of the circle. For samples taken at ebb tide an arrow pointing up, for flood tide an arrow pointing down is added to the vertical line. The stage of tide is further indicated by the position of the circle on the vertical line.

Stommel, Henry, 1953, Computation of pollution in a vertically mixed estuary: Sewage and Industrial Wastes, v. 25, no. 9, p. 1065-1071.

Sverdrup, H. V., Johnson, M. W. , and Fleming, R. H., 1946, The oceans, their physics, chemistry, and general biology: Prentice-Hall, New York, 1946.

Sylvester, R. O., 1952, Pulp mill location study in regard to warr pollution: Sewage and Industrial Wastes, v. 24, p. 508.

The Willapa River estuary, in Washington, discharges into Willapa Bay, which is shallow. The mean annual flow was $613 \mathrm{cfs}$, the mean annual tidal range 7.8 feet. Preparatory to the proposed discharge of wastes from a kraft-type pulp mill, a number of temperature and $\mathrm{pH}$ determinations, 217 chloride determinations and 82 dissolved oxygen measurements were made in July and August of 1950 , a period of low steady stream flow with little precipitation. The $\mathrm{pH}$ decreases and the temperature increases from the bay to the upstream portions of the river. The chloride decreases as shown in figure 1, p. 7 .

Thompson, T. G., 1932 a, The physical properties of sea water: Bull. of the National Research Council, no. 85, Physics of the Earth-V, Oceanography, chap. 4.

Salinity and chlorinity are defined. The composition of sea water in $\mathrm{g} / \mathrm{kg}, \mathrm{moles} / \mathbf{1}$, and equiv. $/ 1$ of $\mathrm{Na}^{+}, \mathrm{Mg}^{++}, \mathrm{Ca}^{++}, \mathrm{K}^{+}, \mathrm{Cl}^{-}, \mathrm{SO}_{4}{ }^{+}, \mathrm{HCO}_{3}{ }^{-}, \mathrm{CO}_{3}{ }^{2}$, and $\mathrm{Br}^{-}$is stated.

Thompson, T. G. and Robinson, R. J., 1932 b, Chemistry of the sea: Bull. of the National Research Council no. 85, Physics of the Earth-V, Oceanography, chap. 5.

The problem of obtaining sea-water samples at known depths is discussed and the Ekman reversing bottle, the Pettersson-Nansen insulated bottle, the Green-Bigelow closing bottle, and the Nansen-Knudsen reversing bottle are described. The approximate composition of sea water, in terms of 27 elements, is stated and the role of each constituent is discussed. The $\mathrm{Mg} / \mathrm{Cl}$ ratio and the $\mathrm{SO}_{4} / \mathrm{Cl}$ ratio are given for river waters of the United States.

Tide Tables, see U. S. Coast and Geodetic Survey.

Tiffany, J. B. , Jr., 1943, Recent hydraulic laboratory developments: Military Engineering, v. 35 , no. 209 , p. 134-140.

A fixed-bed type model reproduces a $40-$ mile reach of the Mississippi River between New Orleans and the Head of Passes. The model reproduced the movement of the saltwater wedge during the low-water period of September and October, 1940. A figure shows the position of the salt-water interface in the model and in the prototype.

Tully, J. P. , 1949, Oceanography and prediction of pulp mill pollution in Alberni Inlet: Fisheries Research Board of Canada, Bull. no. 83, 169 p. , 62 figs.

Alberni Inlet is a typical fiord; its greatest depth exceeds a thousand feet. There are three water layers. In an upper zone of mixed fresh water and sea water, salinity increases from the head of the inlet to the mouth, and the net motion is toward the mouth of the estuary. The depth of this zone increases as the river discharge increases above a critical value. The middle zone is of approximately the salinity of sea water, and the net motion of water is toward the head of the inlet. The third, or deep zone is also of approximately the salinity of sea water, but is quiescent. During flood tide sea water enters the middle zone and is in part transferred to the upper zone by tidal currents. Sea water leaves the inlet on the ebb tide by both the middle and upper layers. Near the river mouths are lateral salinity gradients. The effect of tide, runoff, and wind on the currents and 
chlorinity and temperature gradients were studied in detail. In the summer temperature gradients follow the chlorinity gradients, but in winter the temperature gradients vanish while a salinity distribution persists. In the surface zone dissolved oxygen approaches saturation, but in the middle zone falls off to 60 to 70 percent of saturation in the summer and $\mathbf{8 0}$ to $\mathbf{9 0}$ percent of saturation in the winter. The reduction is due to the oxygen demand of dead plankton sinking from the surface zone. A pollution problem was studied by means of an hydraulic model and from the hydrographic observations.

U. S. Coast and Geodetic Survey, issued annually, Tide Tables, East Coast North and South America, also West Coast North and South America: Coast and Geodetic Survey, Washington 25, D. C. (the Tables for the current year sell for 50 cents each).

U. S. Coast and Geodetic Survey, issued annually, Current Tables, Atlantic Coast, North America, also Pacific Coast, North America and Asia: Coast and Geodetic Survey, Washington 25, D. C. (the Tables for current year sell for 50 cents each).

Wells, R. C., Bailey, R. K., and Henderson, E. P., 1929, Salinity of the water of Chesapeake Bay: U. S. Geological Survey, Professional Paper 154-C, U. S. Government Printing Office, p. 105-154.

From data collected during 1920-21, for 36 stations in the bay the monthly surface and bottom salinities are plotted. Low salinities more frequently occur in the spring months, especially in the upper bay; in the fall the salinity slowly increases. The salinity increases with depth, at the surface remains unchanged throughout a tidal cycle while the bottom salinity varies erratically with the tide. There is a tendency toward higher salinities on the east side of the bay than on the west side at the same latitude. Although this condition has been ascribed to the fact that the principal rivers enter the bay on its west side, evidence is cited that the rotation of the earth may be responsible.

Wicker, C. F. and Rosenzweig, O. , Theories of tidal hydraulics, in Corps of Engineers, U. S. Army, 1950, Evaluation of present state of knowledge of factors atfecting tidal hydraulics and related phenomena: Corps of Engineers, U. S. Army, Report no. 1 of the Committee on Tidal Hydraulics, p. 101-125.

Discusses some of the factors controlling tidal conditions in estuaries and tidal rivers, including the effects of such physical changes as dredging. 